
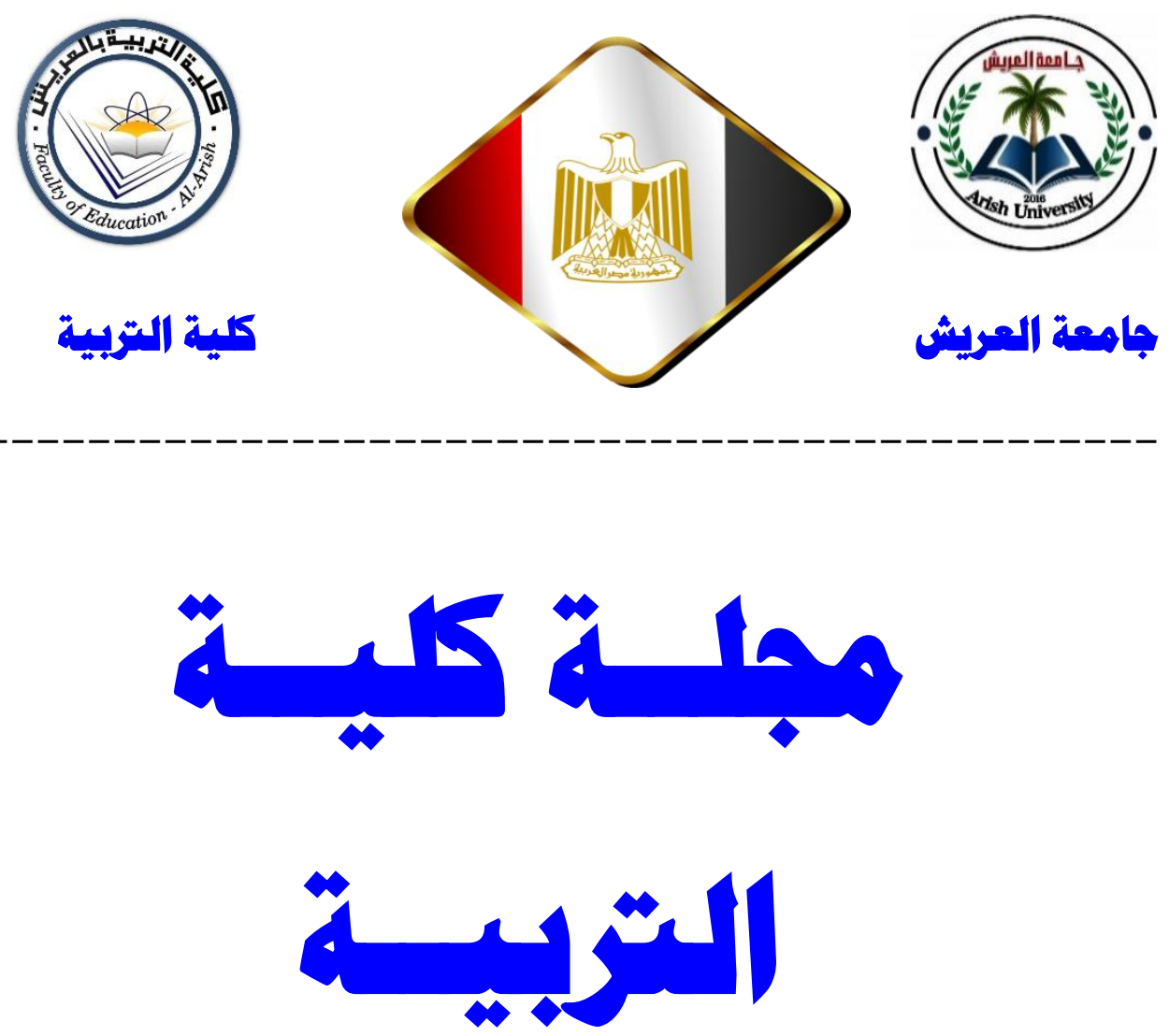

علمية محكمة ربع سنوية

(السنة السادسة - العدد السادس عشر -أكتوبر ^| •؟م)

j_foea@aru.edu.eg 
الإشراف العــــام

\begin{tabular}{|c|c|}
\hline (رئيس مجــد الكلية & أ.د. رفعت عمر عزوز \\
\hline وكيل الكلية للاراسات العليا والبحوث & أ.د. السيد كامل الشربينح \\
\hline
\end{tabular}

هيسئة التمريو

\begin{tabular}{|c|c|}
\hline رئيس التحريز & أ.د. محمد رجب فضل الله \\
\hline مدير التحرير & أ.د. أحمد عبد العظيم سالم \\
\hline عضو & د. كمال طاهر موسى \\
\hline عضو & د. أسماء حسن صبًاح \\
\hline
\end{tabular}

\section{الإشراف المالي والإداري}

\begin{tabular}{|c|c|}
\hline المسؤول المالي & أ. محمد إبراهيم محمد عريبي \\
\hline المسؤول الإداري & أ. أسماء محمد علي الثاعر \\
\hline
\end{tabular}




\section{قواعد النشر بمجة كلية التربية بالعريش}

ا. تتشر المجلة البحوث والدراسات التي تتوافر فيها الأصالة والمنهجية السليمة على ألا يكون

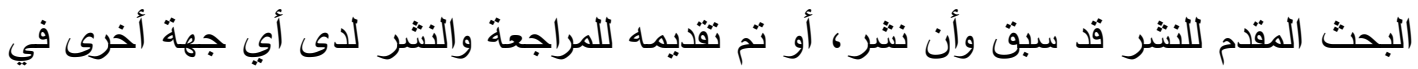
نفس وقت تقديمه للمجلة.

r. تُقبل الأبحاث المقدمة للنشر بإحدى اللغتين: العربية أو الإنجليزية.

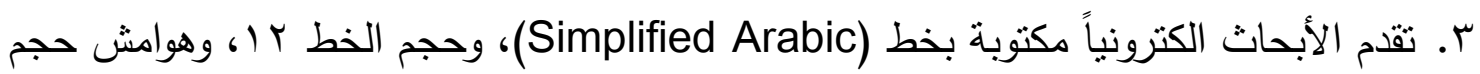
الواحد منها ه.r.بم، مع مراعاة أن تتسق الفقرة بالتساوي ما بين الهامش الأيسر والأيمن وهن (Justify) . وترسل إلكترونياً على شكل ملف (Microsoft Word). ء. يجب ألا يزيد عدد صفحات البحث المُحكم بما في ذلك الأشكال والرسوم والمراجع والجداول والملاحق عن (ro) صفحة. (الزيادة بحد أقصى ، (1 صفحات برسوم إضافية). ولا يزيد البحث المُستل عن ( • r صفحة ) (الزيادة بحد أقصى م صفحات برسوم إضافية). ه. يقدم الباحث ملخصاً لبحثه في صفحة واحدة، تتضمن الفقرة الأولى ملخصاً باللغة العربية، والفقرة الثانية ملخصاً باللغة الإنجليزية، وبما لا يزيد عن .. ب كلمة لكل منها. 7 . يكتب عنوان البحث واسم المؤلف والمؤسسة التي يعمل بها على صفحة منفصلة ثم يكتب عنوان البحث مرة أخرى على الصفحة الأولى من البحث. V. يجب عدم استخدام اسم الباحث في متن البحث أو قائمة المراجع ويتم استبدال الاسم بكلمة

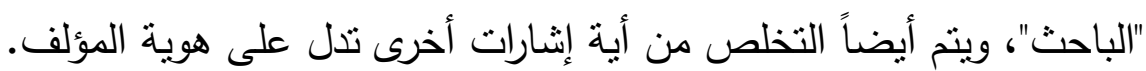

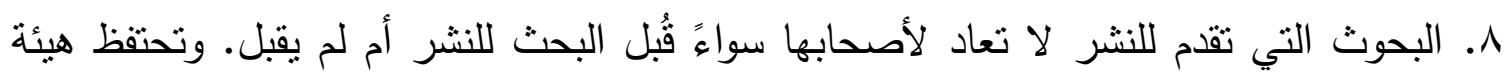
التحرير بحقها في تحديد أولويات نشر البحوث. 9 . لن ينظر في البحوث التي لا تتفق مع شروط النشر في المجلة، أو تلك التي لا تشمل على ملخص البحث في أي من اللغتين، أو يزيد عدد صفحاتها عن هب صفحة شاملة الصفحات

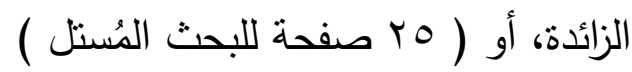
• . . يقوم كل باحث بنسخ وتوقيع وإرفاق إقرار المواققة على اتفاقية النشر . 
11 ( بسهم الباحث في تكاليف نشر بحثه، ويتم تحويل التكلفة على الحساب الخاص بالمجلة. يجب إرسال صورة عن قسيمة التحويل أو دفع المبلغ، مع البحث الكترونيا. التكاليف تشمل: مكافأة

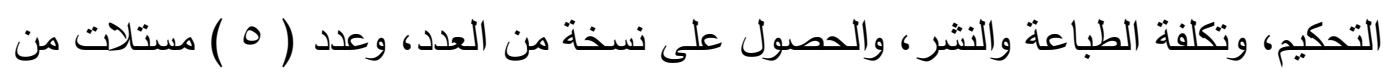

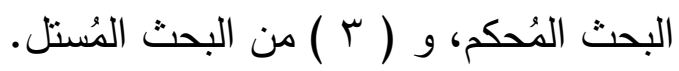
ب ا. يتم نشر البحوث أو رفض نشرها في المجلة بناءً على تقاربر المحكمين، ولا يسترد المبلغ في حالة رفض نشر البحث من قبل المحكمين. سا. يُمنح كل باحث إفادة بقبول بحثه للنشر بعد إتمام كافة التصويبات والتعديلات المطلوبة، وسداد الرسوم المقرة.

\section{قواعد التمكيم بمبلة كلية التثبهية بالمريشي}

فيما يلي القواعد الأساسية لتحكيم البحوث المقدمة للنشر بمجلة كلية التربية بالعريش

\section{القواعد عامهة:}

1. ـ مدى ارتباط موضوع البحث بمجال التربية. r. مدى مناسبة الدراسات السابقة، وإبرازها لرؤى متعددة.

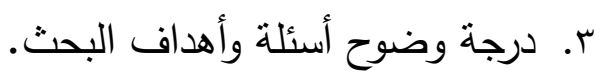

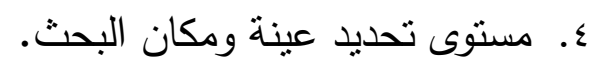
ه. درجة إتباع البحث لمعايير التوثيق المحددة في دليل رابطة علم النفس الأمريكية، العدد السادس.

ا. احتواء قائمة المراجع على جميع الدراسات المذكورة في منن البحث والعكس أيضاً صحيح.

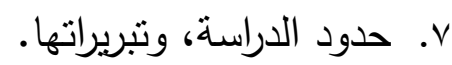
^. سلامة تقرير البحث من الأخطاء اللغوية المتعلقة بالنحو والإملاء وكذا المعنى. 9. تكامل جميع أجزاء تقرير البحث، وترابطها بشكل منطقي.

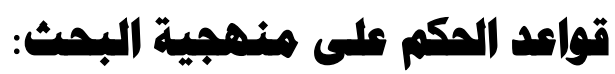
ا. تحديد الفترة الزمنية للبحث. 
r. تحديد منهجية مناسبة للبحث. r. تبرير إجراءات للاختيار في حالة دراسة الأفراد أو الجماعات. ء. تضمين البحث إطاراً نظرياً واضحاً. ه. توضيح الإجراءات المتعلقة بالجوانب المهنية الأخلاقية منل: الحصول على موافقة

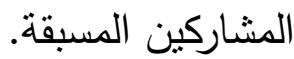

\section{قواعد تمكيم الإبمراكات:}

1. شرح وسائل جمع المعلومات بوضوح، والعمليات المتبعة فيها. r. تحديد وشرح المتغيرات المختلفة.

r. نترقيم جميع الجداول والأشكال والصور والرسوم البيانية بشكل مناسب وتبوييها والتأكد من سلامتها. ع. شرح عملية التحليل المتبعة ومبرراتها، والتأكد من اكتمالها وسلامتها. قواعد الهكم على النتاجه:

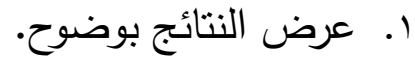

r. توضيح جوانب الاختلاف في حالة تعارض نتائج البحث مع نتائج الدراسات السابقة. r. اتساق الخاتمة والتوصيات مع نتائج البحث. 


\section{همتويات العدد ( 17 )}

\begin{tabular}{|c|c|c|c|}
\hline \multicolumn{2}{|c|}{ هيئة التحرير } & \multicolumn{2}{|l|}{ قيادة ودماء بحديدة ثابتة... قيم } \\
\hline الصفمات & الباحث & عنمان البمث & الرقم - الرق \\
\hline \multicolumn{4}{|c|}{ 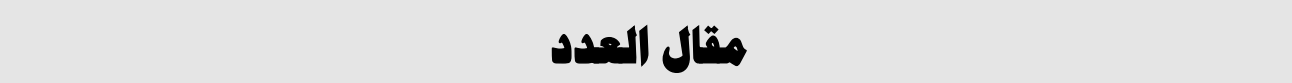 } \\
\hline $13-46$ & 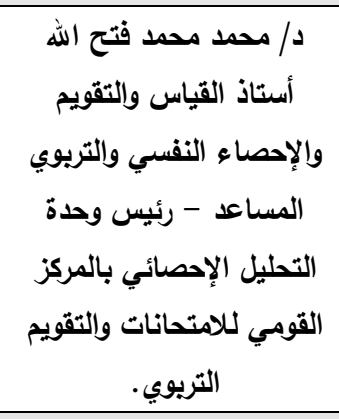 & بنوك الأسئلة والتصحيح الإلكتروني: & \\
\hline \multicolumn{4}{|c|}{ بموث ودراسات مصكمة } \\
\hline 49-96 & 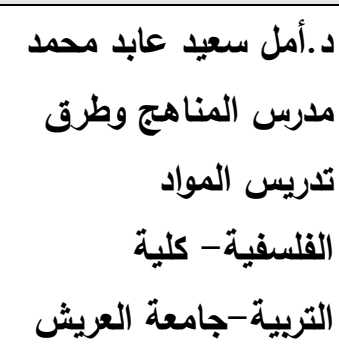 & 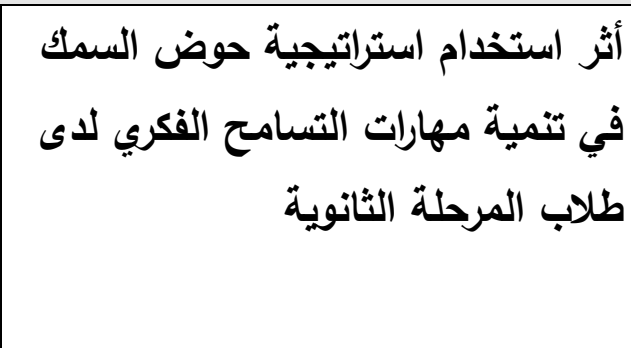 & 1 \\
\hline $97-134$ & $\begin{array}{l}\text { Dr. Mahdi M. A. } \\
\text { Ibrahim } \\
\text { Assistant Professor } \\
\text { ،of TEFL } \\
\text { Dept. of Curriculum } \\
\text { \& Instruction } \\
\text { Faculty of } \\
\text { Education, Arish } \\
\text { University }\end{array}$ & $\begin{array}{l}\text { The Effectiveness of Using } \\
\text { the SCAMPER Model in } \\
\text { Enhancing EFL Learners' } \\
\text { Essay Writing Skills and } \\
\text { their Attitudes towards it }\end{array}$ & r \\
\hline $\begin{array}{c}135- \\
185\end{array}$ & محمد دينا محمد أحمد & الفروق في جودة الحياة لاى الطلاب & $r$ \\
\hline
\end{tabular}




\begin{tabular}{|c|c|c|c|}
\hline & كلية التربية التربية الخاصة -جامعة & بعض المتغيرات & \\
\hline \multicolumn{4}{|c|}{ 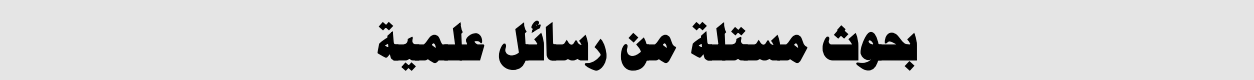 } \\
\hline $\begin{array}{l}189- \\
222\end{array}$ & 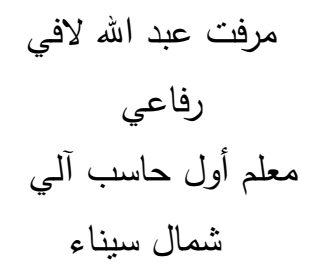 & 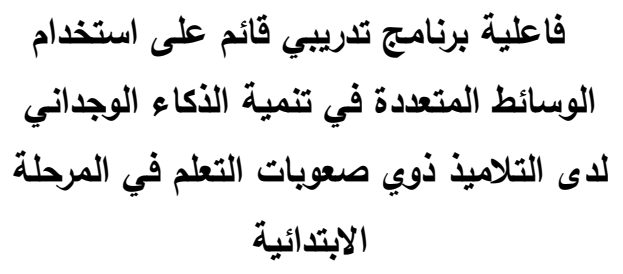 & 1 \\
\hline $\begin{array}{l}223- \\
257\end{array}$ & 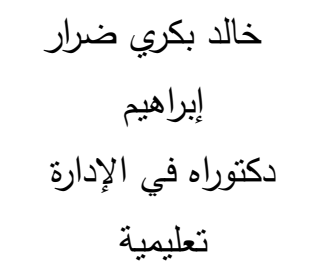 & 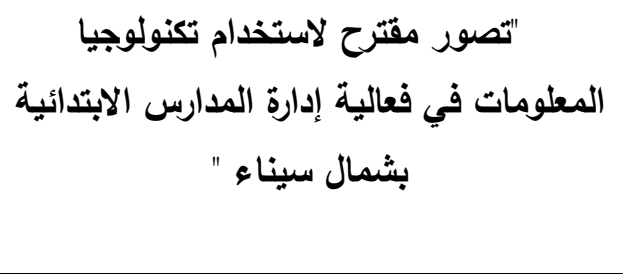 & $r$ \\
\hline $\begin{array}{c}259- \\
292\end{array}$ & 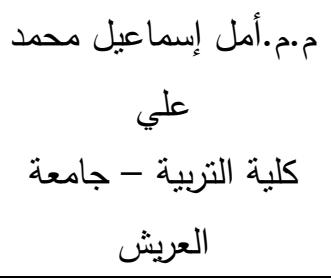 & فاعلية برنامج قائم على الدعامات التعليمية & $r$ \\
\hline
\end{tabular}




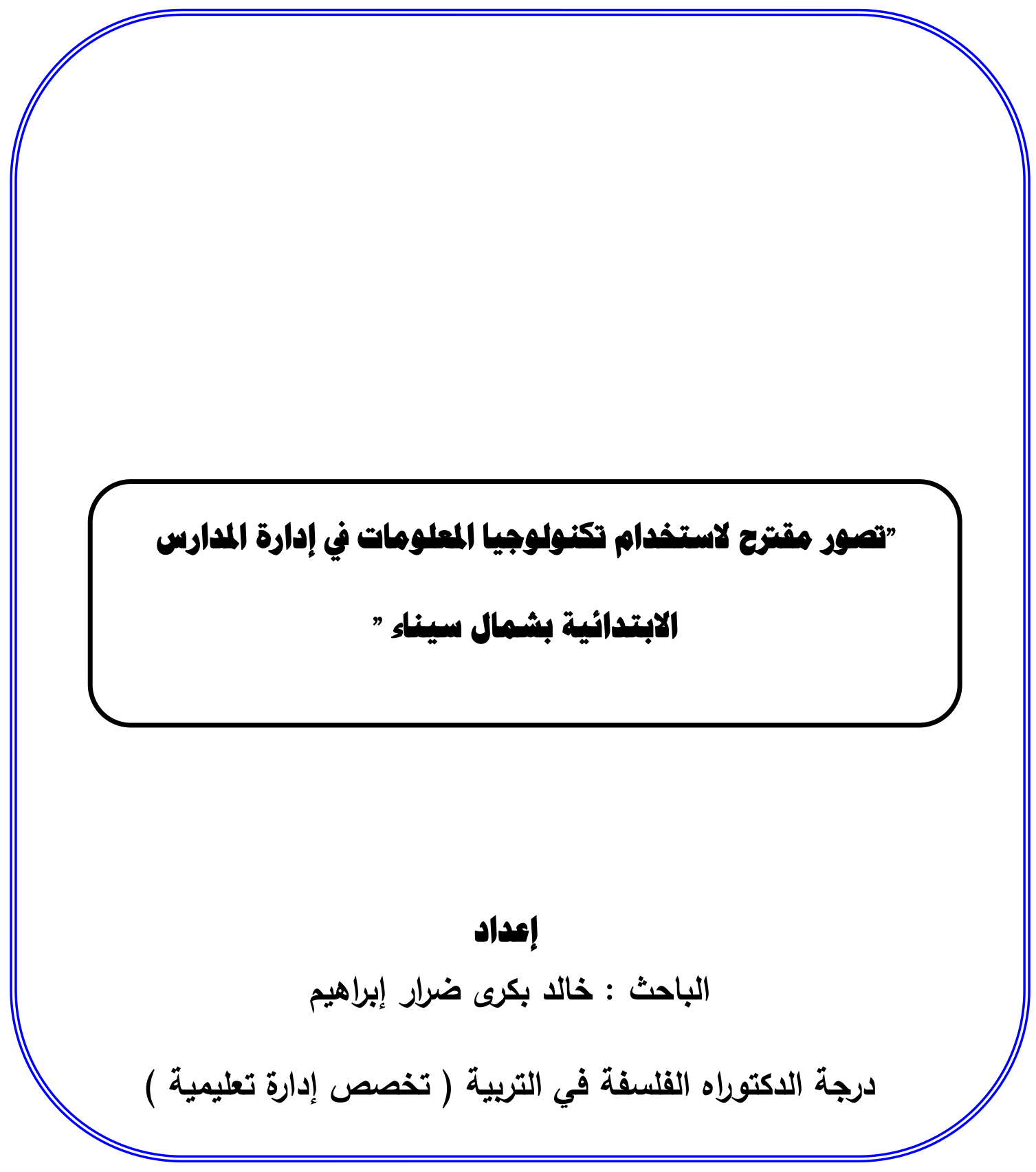




\section{טaill}

تهدف الدراسة إلى التعرف على واقع استخدام تكنولوجيا المعلومات لتحقيق فعالية إدارة المدارس

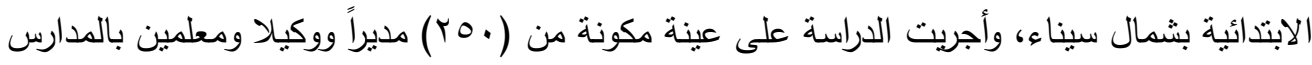
الابتدائية بالإضافة لبعض الإداريين بمعامل الحاسب الآلي، واعتمدت الدراسة على المنهج الوصفي ، وتوصلت الدراسة إلى : أن استخدام تكنولوجيا المعلومات يساعد إدارة المدرسة فى أنجاز الكثير من

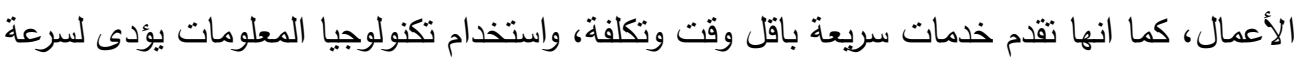
تخزين المعلومات واستدعاء البيانات المطلوبة فى اى وقت، كما أتضح وجود القصور التكنولوجي بالعديد من المدارس ويرجع ذلك لضعف الوعى لدى الإدارة المدرسية بأهمية تكنولوجيا المعلومات ، واشتملت الدراسة على ست فصول الأول الاطار العام، والثاني الأسس النظرية لتطبيق تكنولوجيا المعلومات بالمدارس الابتدائية، و الثالث استخدام تكنولوجيا المعلومات لتفعيل إدارة المدرسة، و الفصل الرابع الفلسفة التربوية والتنظيمية لإدارة المدرسة الابتدائية ، و الخامس الدراسة الميدانية وتحليل النتائج وتفسيراتها، وفي الفصل السادس تم وضع التصور المقترح لاستخدام تكنولوجيا المعلومات لتحقيق فعالة ادارة المدارس ، الانتدائسة شمال ، سناء. 


\section{"تصور مقترح لاستخدام تكنولوجيا المعلومات في فعالية إدارة المدارس الابتدائية بشمال سيناء "خالد بكرى ضرار إبراهيم \\ دكتوراه في التربية تخصص ( إدارة تعليمية )}

\section{مقدمة}

فى ضوء التطور السريع والمتلاحق الذى يشهده العصر فى تقنيات التعليم

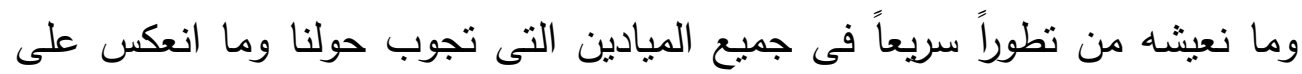
الحياة عامة ،واصبح معدل التغير أكبر من معدل اللحاق بالتطور أو حتى مجرد

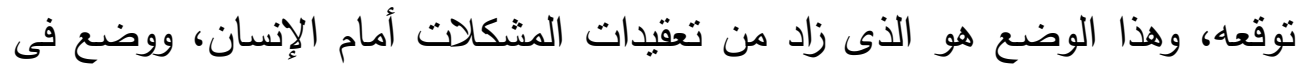
طريقه تحديات أكبر من إمكانياته التقليدية .وفى هذا الوقت أصبحت عملية توظيف تكنولوجيا المعلومات مطلب ملح فى العملية التعليمية عامة وإدارة المدرسة الابتدائية خاصة، وهذا ينطلب من المؤسسات التعليمية أن تعى تكنولوجيا المعلومات وتتفهم دورها فى تتظيم وجودة الإدارة المدرسية الفعالة . وبناءً على المشكلات وجوانب القصور المتعددة التى تجوب إدارة المدرسة الابتدائية ظهرت اتجاهات حديثة ربما تقيد فى التخلب على هذه المشكلات ، والقضاء على القصور الموجود بها ـ من هذه الاتجاهات المعاصرة التى ظهرت فى علم الإدارة ما يسمى بالتكنولوجيا الادارية الحديثة حيث أنها من أهم الصيغ التى فرضت نفها نها

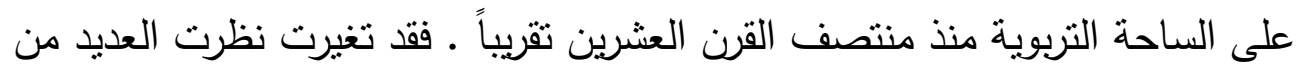
الدول المتقدمة والنامية على السواء، وادركت الدور الذى بمكن أن تقوم به التكنولوجيا الإدارية فى تجويد العمل الإداري بالمؤسسات التعليمية، ومنها إدارة المدرسة الابتدائية

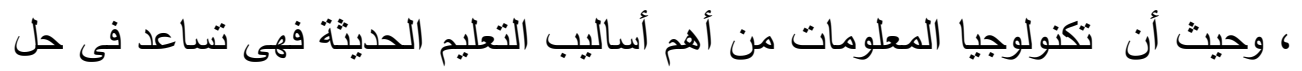

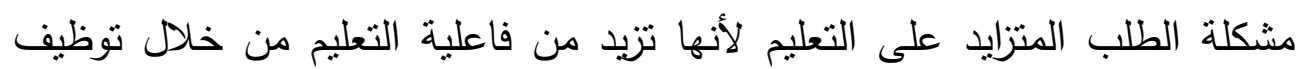

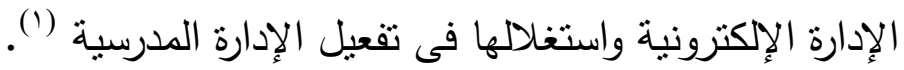

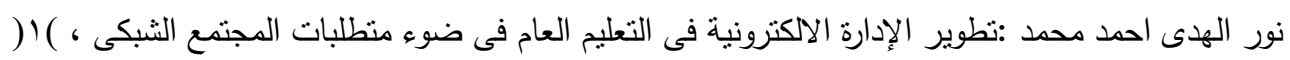

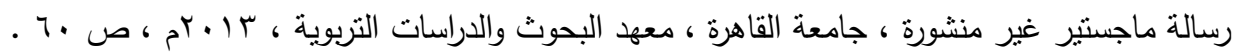


من المؤكد أن تكنولوجيا المعلومات يمكن أن تقوم بدور رئيسي فى تطوير العمل الإداري والفني بالمدرسة الابتدائية وغيرها من مدارس التعليم قبل الجامعي ، إذ يمكن

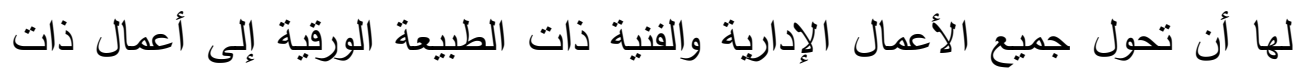

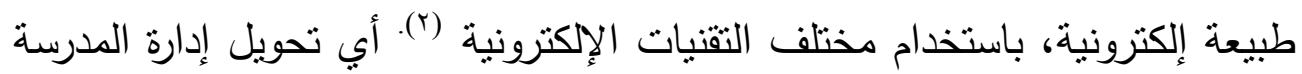

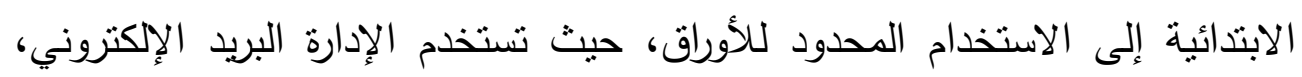
والأشيف الإككتروني، والمفكرات الإلكترونية بدلاً من أوراق وسجلات، والإدارة الإلكترونية إدارة بلا تتظيمات ولوائح جامدة ، وتعتمد على الإنى

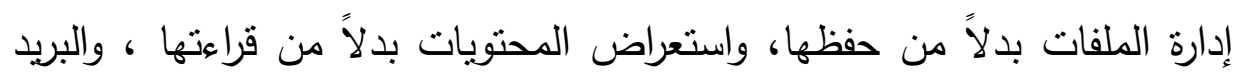

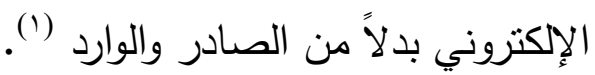
علاوة على ذلك استخدام تكنولوجيا المعلومات فى المدرسة الابتدائية يساعد على لى لئ تحويل العمل اليدوي إلى عمل إلكتروني، وتوفير قواعد بيانات خاصة بكل الطلاب

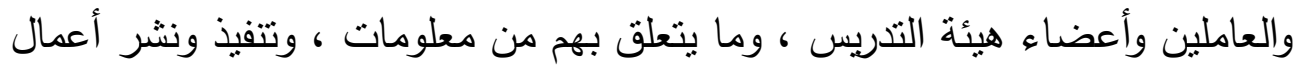
المدرسة إلكترونياً ، ومتابعة المراسلات مع الجهات المختلفة داخل المدرسة وخارجها مهاه إلكترونياً على شبكة الأنترنت وإتاحة الفرصة لأولياء الأمور للوقوف لعنى على المستوى

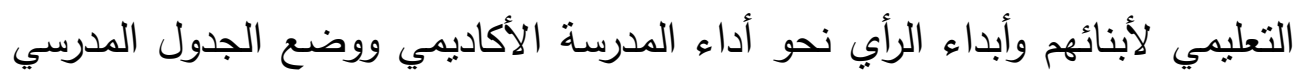

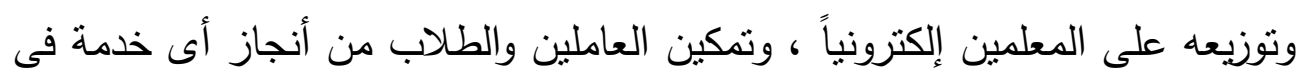
أى وقت ومن أى مكان عن طريق موقع المدرسة الإلكتروني على شبكة الأنترنت وتمكين متخذي القرار بالإدارات التعليمية والمديريات والوزارة من الحصول على تقارير

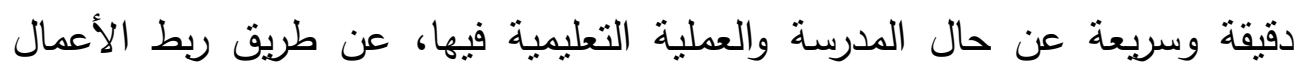
الإدارية بالمدرسة بشبكة واحدة لتوحيد البيانات التى تخص المدرسة ، مما يساعد هذه

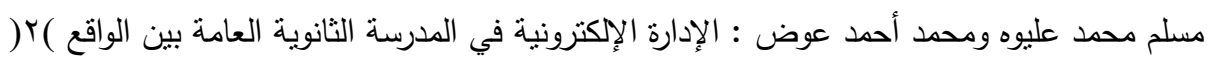
والمأمول ، دراسة ميدانية على منطقة المدينة المنورة ، مجلة كلية التربية ، بنى سويف ، العدد (؟) ، مجلد

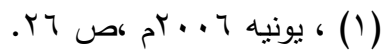

1- N. Skonars, Educating with the Internet - Using Net Resources at School and Home, Masschusetts, Charies River Media , 1999 , p.65 . 
الجهات ( الإدارة والمديرية والوزارة ) على اتخاذ القرار السليم على اساس موضعي

وانطلاقاً من أن المدرسة الابتدائية مرحلة مهمة فى التربية والتتشئة لكافة أفراد

المجتمع وإعدادهم ليصبحوا قادرين على التفاعل مع كثير من المتغيرات العلمية والتقافية والسياسية والاقتصادية والاجتماعية - التى يتسم بها العصر الحالي، هذا بالإضافة إلى موقعها المهم في بداية السلم التعليمى، لذلك تعد تلك المدرسة مدخلا

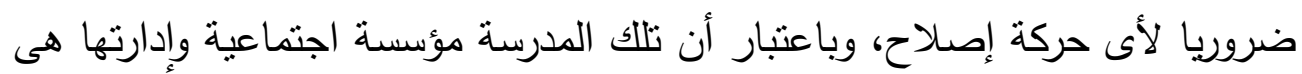

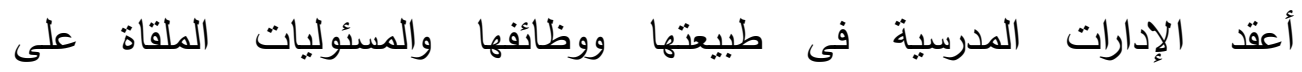

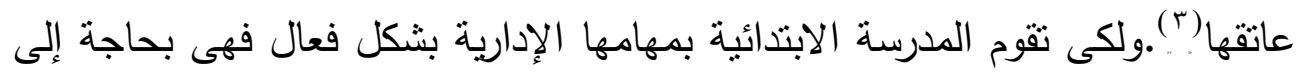

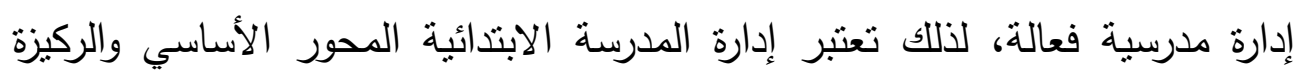
الرئيسة التى تقوم عليها العملية التعليمية والتربوية فى مختلف المدارس الابتدائية، فهى ترسم المعالم والطرق وتغير السبل أمام العاملين فى الميدان التربوى، وتحدد

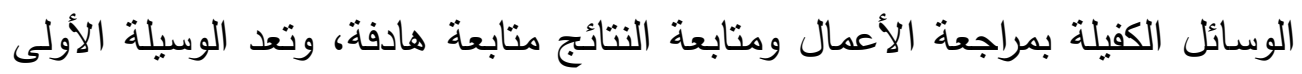
والأخيرة فى تتفيذ الأهداف والسياسات الكبرى للوطن باعتبارها الجهاز الإشرافي

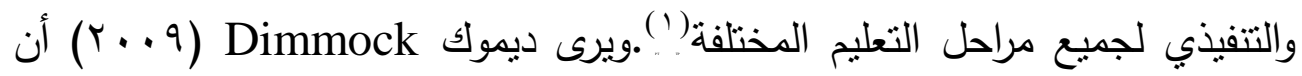

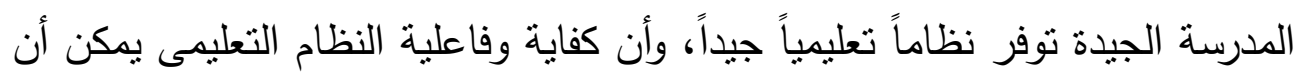

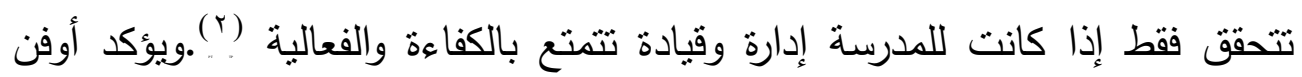

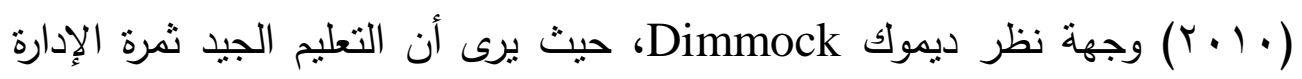

2- Ibid,pp.67-68.

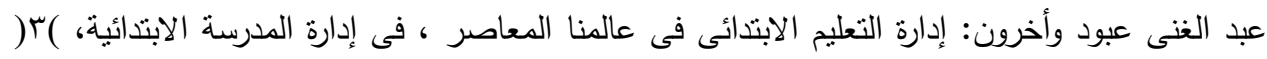

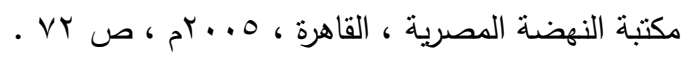

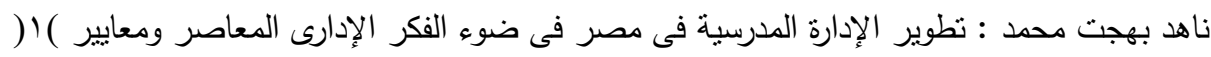

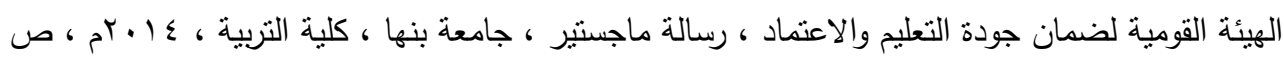
. r

2-Cliv Dimmock;" Manangig for Quality and Accountability in Western Australian Education" Educational Review Journal, Vol 42, No. 2, 2009, p 40 . 
المدرسية الجيدة، وأن القيادة المدرسية أهم عنصر فى العملية التعليمية، فهى المسئولة عن المدرسة وعن كيانها ونظامها والعمل والحياة داخلها، ومهما وضع للمدرسة من

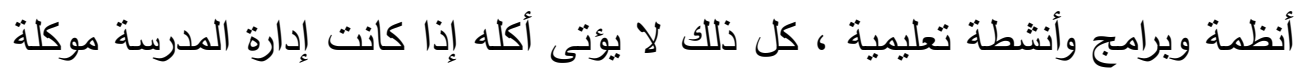

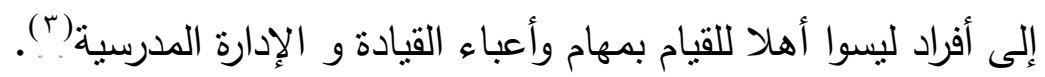
وبذللك فإن تكنولوجيا المعلومات تعنى الانتقال من العمل التقليدى إلى تطبيقات معلوماتية بما فيها شبكات الحاسب الآلي، لربط الوحدات التنظيمية مع بعضها لتسهيل الحصول على البيانات والمعلومات، لاتخاذ القرارات المناسبة، وإنجاز الأعمال، وتقديم الخدمات للمستقيدين بكفاءة وفعالية، بمعنى أن الإدارة الإلكترونية

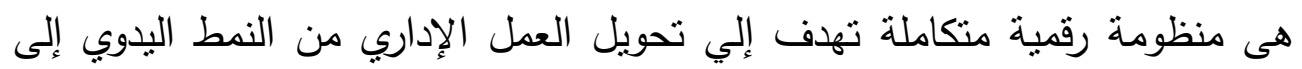
النمط الإلكتروني، وذللك بالاعتماد على نظم معلوماتية نساعد على اتخاذ القرار الإداري فى وقت سريع، وبأقل الجهد والتكلفة، ويترتب على ذلك سرعة إنجاز الأعمال ، وخفض تكاليف العمل الإداري، ورفع أداء الإنجاز، وتجاوز مشكلة البعدين الجغرافي والزمنى، والحد من البيروقراطية، وتطوير آلية العمل و وجود بنية معلوماتية آمنة ( ).

\section{مشكثة الدراسة}

تواجه الإدارة المدرسية تحديات الثورة المعلوماتية التى ألقت بانعكاساتها على مختلف جوانب العملية التربوية والتعليمية، ومع التغيرات العالمية والمحلية المعاصرة والاهتمام بدور التعليم أصبحت الحاجة ماسة لتوفير إدارة مدرسية ذات كفاءة عالية لتحقيق فعالية إدارة المدرسة الابتدائية لتتوافق مع مفاهيم ومنطلبات العصر الحالي، حيث تعتبر تلك المرحلة أهم مرحلة لما لها أثر فعال في مستقبل التلاميذ، وعلى الرغم من كل الجهود التى تبذلها وزارة التربية والتعليم والمؤسسات التعليمية للإصلاح المدرسى، وبالرغم من تطبيق الإدارة الإلكترونية فى التعليم الابتدائي بغرض نطويره

3- Joslyn,Owen :Managing Education,3rd,ed ,Longmon Group UK Ltd,London. 2010, p62.

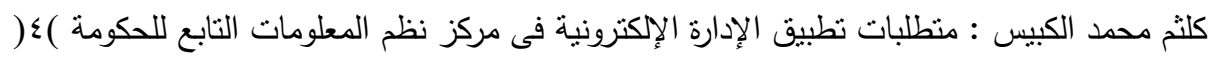

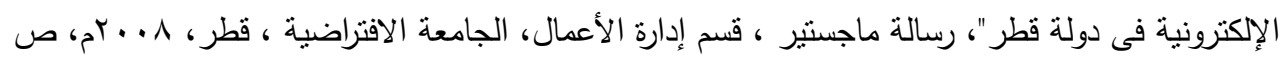
.2 
وتفادى المشكلات الناجمة عن استخدام الأساليب التقليدية فى العمل الإدارى، التى يؤدى بعضها إلى تزايد الأخطاء وبطء اتخاذ القرارات، وإهدار جهة ووقت الإدارة المدرسية، إلا أنه مازالت هناك العديد من المشكلات التى نؤثر فى تحقيق فعالية إدارة المدرسة الابتدائية.

ومن خلال إطلاع الباحث على عدد من الدراسات السابقة وثيقة الصلة بموضوع الدراسة وجد أن هناك بعض الدراسات تشير لعدد من المعوقات والتحديات

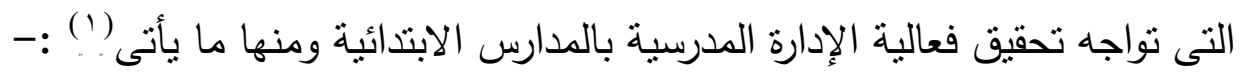

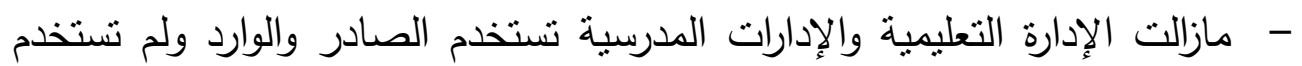
البريد الإككتروني في المراسلات الوظيفية . - قصور المهارات الأساسية لاستخدامات الحاسبات الآلية لاى كثير من العاملين بالمدرسة الابتدائية.

(السيد عبد السلام محمد : دراسة ميدانية لبعض مشكلات المدرسة الابتدائية ومواجنها فى ضوء الفكر ) (

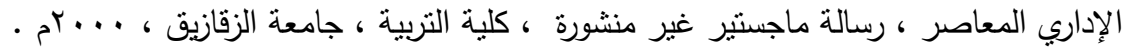
وانظر أيضا:

- مصطفى حسين محمود: تطوير إدارة المدرسة الابتدائية فى ضوء بعض النماذج الإدارية الحديثة ، رسالة

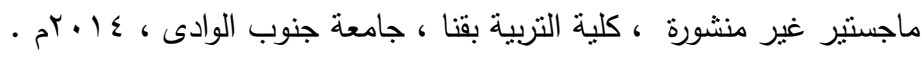

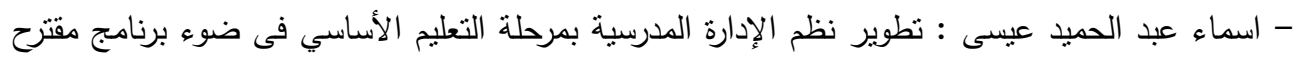

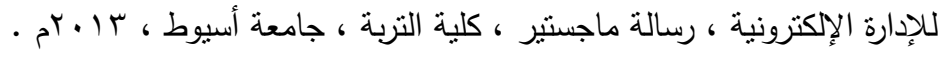

- لبنى عبد الرحمن السيد : نطوير إدارة مدارس التعليم الابتدائي باستخدام تكنولوجيا المعلومات والاتصالات لتحقيق الجودة الثاملة بها دراسة حالة فى محافظة بور سعيد ، رسالة ماجستير غير منشورة ، كلية التربية ،

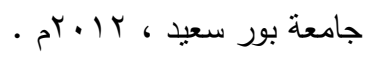

- فلاح سعد الطامى : تطوير إدارة المدرسة الابتدائية بدولة الكويت لمواجهة تحديات مجتمع المعرفة ، رسالة

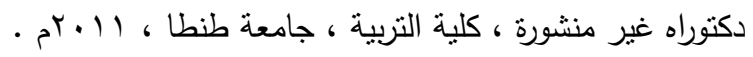

- رأفت رضوان : الإدارة الإككترونية ، بحث مقدم إلى الملتقى الإداري السعودى الثانى للجمعية السعودية

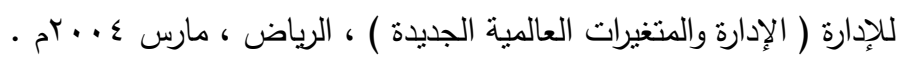


- قلة الاهنمام بعقد الندوات والمحاضرات وورش العمل لنشر نقافة الإدارة الإلكترونية بين العاملين بالمؤسسات التعليمية.

- النأقلم مع النظم اليدوية المعتادة فى العمل ودوراتها المستتدية، ورفض التحديث والتغيير

- - انخفاض كفاءة مستوى الكثير من الإداريين فى التعامل مع تطبيقات تكنولوجيا المعلومات والاتصالات واستخدامات الحاسب الآلي وبرامجه المثتوعة. - قلة الموارد المالية المخصصة لتكنولوجيا الاتصالات فى المدرسة الابتدائية . - الحاجة إلى وجود قوانين تحكم عمل الإدارة الإلكترونية بالمدارس. - الحاجة الماسة إلى مبان مدرسية تستوعب تقنيات الإدارة الإككترونية . - أن الإدارة المدرسية لا تأخذ بمبداء تقويض السلطات وتحديد المسؤوليات طبقا

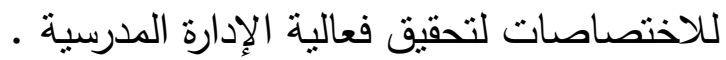
- ضعف استثمار الإدارة المدرسية بالتعليم الابتدائي للموارد البشرية والمادية المتاحة لدعم عمليتي التعليم والتعلم بمدارسها . - قصور إدارة المدرسة الابتدائية عن تبنى المستحدثات التكنولوجية فى التعليم. - تعدد القيادات الإدارية بالمدرسة الابتدائية وقلة وعى المديرين بالخبرة وغياب فلسفة الجودة الثناملة لديهم. - انخفاض مستوى تشجيع إدارة المدرسة الابتدائية للأفكار الجديدة التى تدعو إلي التحسين فى مجال العمل وربما يرجع ذلك إلي مركزية الإدارة والتزامها بالقوانين واللوائح المنظمة للعمل داخل المدرسة وفى ضوء الإمكانات المتاحة. - حاجة إدارة المدرسة الابندائية لمسايرة المبادئ والأساليب الإدارية الحديثة، وتركيزها على الجوانب الإدارية التقليدية. - مجود أوجه قصور للإدارة المدرسة الابتدائية فى استخدام تكنولوجيا المعلومات والاتصالات على المستويين الإداري والتعليمي مما يعيق أحداث جودة نوعية في أداء المدرسة وإنتاج مخرج تعليمي غير قادر على مواكبة عصر التكنولوجيا ومستحدثاتها. 
- ضعف الصلاحيات والسلطات الممنوحة لمستويات الإدارة المدرسية، وأيضا ضعف قدرات القادة بالمدارس الإبتدائية. - - نقص الموارد المالية، والتمسك بحرفية اللوائح والنشرات. وبالرجوع إلى الإحصائيات الرسمية عن عدد المدارس الابتدائية ومديريها ونظارها ووكلائها بمحافظة شمال سيناء وجد أن إجمالي عدد المدارس ( ror) مدرسة وتضم إدارة العريش عدد(OV) مدرسة ابتدائية، وتضم إدارة الثيخ زوبد عدد (؟Y) مدرسة ابتدائي، كما تضم إدارة بئر العبد عدد (^^) مدرسة ابتدائية ، بينما تضم إدارة رفح عدد (1/) مدرسة ابتدائية، وكذلك تضم إدارة الحسنة عدد ( (00) مدرسة ابتدائية، وتضم إدارة نخل عدد (·r) مدرسة ابتدائية. وبلغ عدد المديرين

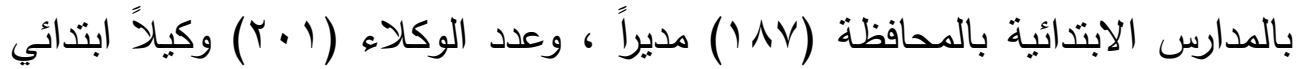

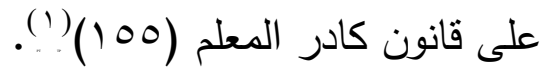

وحيث إن إدارة المدرسة الابندائية فى مصر عامة وشمال سيناء خاصة بها العديد من أوجه القصور والمشكلات والمعوقات والتحديات التى تحول دون تحقيق أهدافها المنشودة، وضمانا لتحقيق فعالية إدارة المدرسة الابتدائية، يسعى الباحث إلى لى إجراء هذه الدراسة وذللك من خلال الإجابة عن السؤال الرئيس وتتمثل فى: كيف يمكن استخدام تكنولوجيا المعلومات فى تحقيق فعالية إدارة المدارس الإسه الابتدائية بشمال سيناء ؟ ويتقرع من هذا السؤال الرئيس الأسئلة التالية:

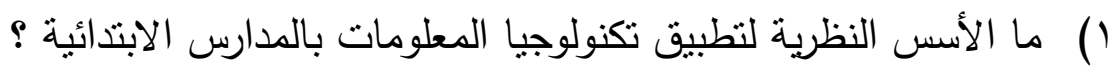
r) كيف يمكن استخدام تكنولوجيا المعلومات لتفعيل إدارة المدرسة الابتدائية ؟ r) ما الفلسفة التربوية والتنظيمية لإدارة المدرسة الابتدائية فى مصر ؟ ع) ما واقع استخدام تكنولوجيا المعلومات بالمدارس الابتدائية ؟ 0) ما التصور المقترح لاستخدام تكنولوجيا المعلومات فى تحقيق فعالية إدارة المدارس الابتدائية بشمال سيناء ؟ مل

() محافظة شمال سيناء : مديرية التربية والتعليم ،مكتب إدارة الإحصاء ، تم الحصول على المعلومة )

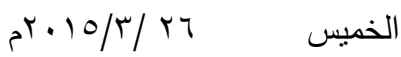




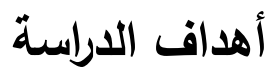

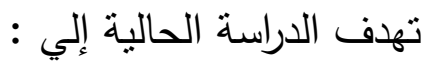

(1) التعرف على الأسس النظرية لتطبيق تكنولوجيا المعلومات بالمدارس الابتدائية.

r) تحديد مجالات استخدام تكنولوجيا المعلومات لتقعيل إدارة المدرسة الابتدائية. r) التعرف على الفلسفة التزبوية والتنظيمية لإدارة الددرسة الابتدائية فى مصر. ع) تتخيص واقع استخدام تكنولوجيا المعلومات بالمدارس الابتائية بشمال سيناء

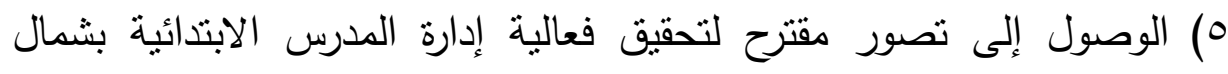
سيناء باستخدام تكنولوجيا المعلومات.

أهمية الدراسة ومبرراتها

تعتبر هذه الدراسة محاولة لنطبيق فعالية إدارة الدارس الابتدائية بشمال سيناء باستخدام تكنولوجيا المعلومات، وذلك من خلال تعرف فلسفة وأهداف إدارة

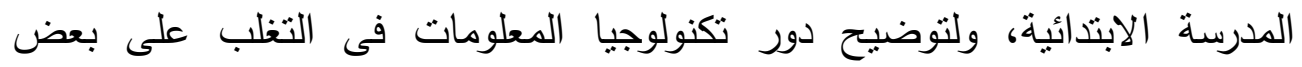
التحديات والمعوقات التى تحيل دون تحقيق الفعالية بإدارة الددارس الابتدائية، وذللك

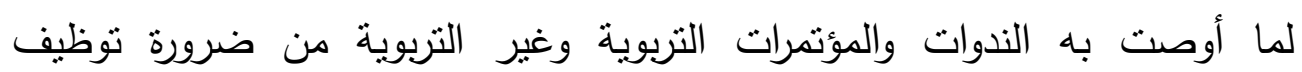
تكنولوجيا المعلومات والاتصال الحديثة فى تطوير وتجويد الأداء فى الددارس وغيرها،

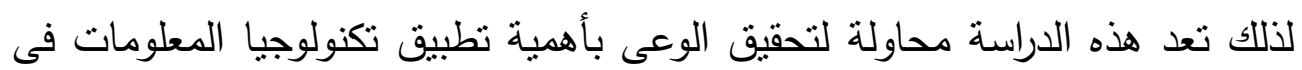

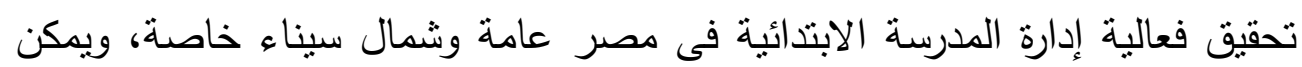

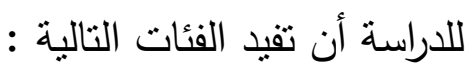
1- صانعوا السياسة التعليمية الدرسية: سوف يكون لايهم فهم أفضل للمعوقات

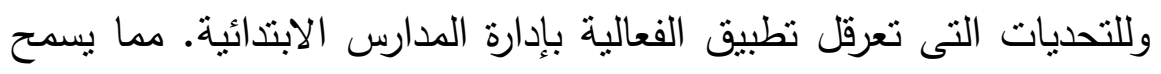
لهم تقديم دعم مستدام لتوفير منظومة إدارية مدرسية متميزة . r- قيادات الدارس الابتدائية: سوف يكون لديهم فهم أفضل لكيفية استخدام تكنولوجيا المعلومات في تحقيق إدارة مدرسية فعالة . 
r- المعلمون: سوف يستقبدون من استراتيجيات تكنولوجيا المعلومات والحلول المقترحة لمعوقات تطبيقها، وآليات استخدامها لتحقيق أداء مدرسى وصفي ليني فعال. ع - الطلاب وأولياء الأمور والباحثون: سوف يستقيدون من نتائج الدراسة، ومن الممارسات المهنية التى تقدمها قيادات المدرسة الابتدائية والمعلمون نتيجة استخدامهم لاستراتيجيات تكنولوجيا المعلومات فى الإدارة المدرسية والصفية بطريقة فعالة .

حدود الدراسة - الحدود الأكاديمية: افتصرت الدراسة على ممارسات إدارة المدرسة الابتدائية فى مجالات: التخطيط ، والتتظيم، والتوجيه، والرقابة، والتقويم الحدود المكانية : اقتصرت الدراسة على المدارس الابتدائية بإدارة العريش وإدارة

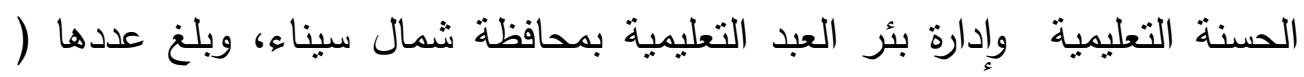

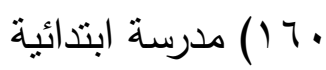

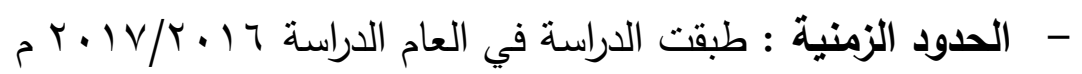

\section{منهج الدراسة}

فرضت طبيعة الدراسة استخدام المنهج الوصفي، الذى يتم من خلاله رصد

الواقع الفعلى لاستخدامات تكنولوجيا المعلومات فى إدارة المدرسة الابتدائية، من خلال وصف الحقائق والظروف الراهنة، وجمع البيانات وتتظيمها وتصنيفها وتحليلها

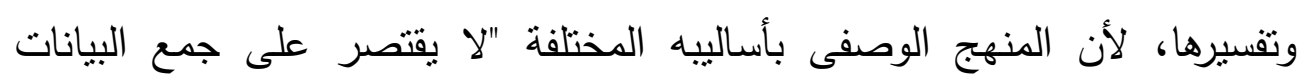
وتبويبها، وإنما يمضى إلى ما هو أبعد من ذلك، حيث يتضمن قدراً من التفسير لهذه البيانات(1)، وذلك لنتخيص واقع استخدام تكنولوجيا المعلومات بالمدارس الابتدائية. أدواث البحث

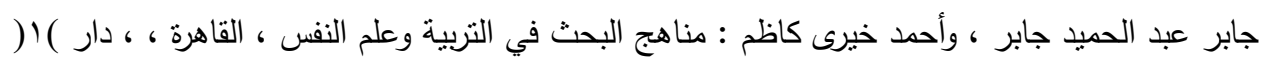

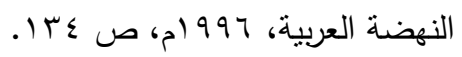


لجمع البيانات وتحليلها والاستفادة منها فى فهم الواقع تم استخدام الأدوات التالية : - - مقابلات شخصية مفتوحة ومقننة مع مسئولين ومستفيدين من المدرسة الابتدائية

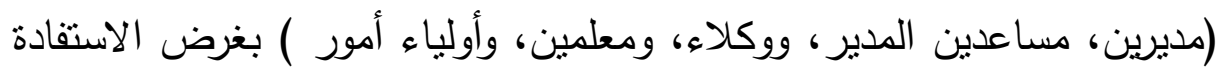
من آرائهم لتعرف واقع إدارة المدرسة الابتدائية، ومدى استخدام تكنولوجيا المعلومات فى تحقيق فعالية إدارة المدرسة الابتدائية. r- استبانة - أعدها الباحث - على عينة عشوائية من المعلمين والمديرين والوكلاء والإداريين والفنيين بالمدارس الابتدائية من خلا زيارة استطلاعية بغرض الاستفادة من آرائهم لتعرف على واقع تطبيق و استخدام تكنولوجيا المعلومات

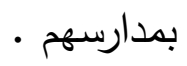

\section{مصطلحات الاراسة}

\section{الفعالية Effectiveness}

الفعالية فى المعجم العربي مأخوذة من فعل الثيء أى عمله، تعنى مقدرة الثىء على (الثى التأثنر (').وفى المعجم الأجنبي مأخوذة من effective وترجمنتها فعال، وتعنى

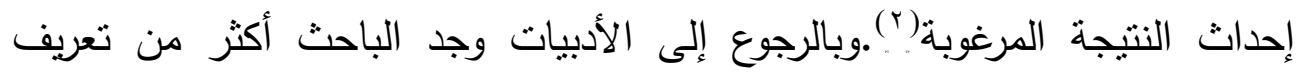
للفاعلية، منها على سبيل المثال :بأنها " مدى إنجاز الأهداف أو المخرجات المنشودة الهداب

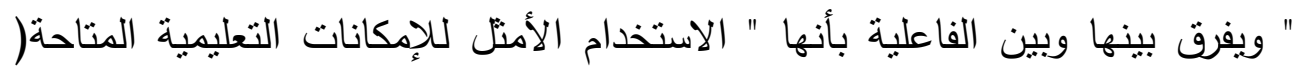
المدخلات) من أجل الحصول على نواتج ومخرجات تعليمية معينة، فهي الحصول على أكبر قدر من المخرجات التعليمية باستخدام أدنى مقدار من المدخلات التعليمية

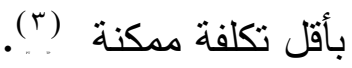

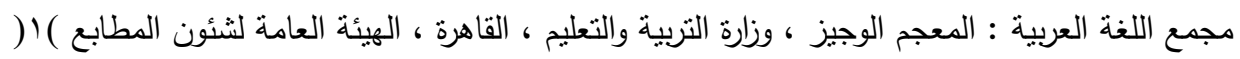

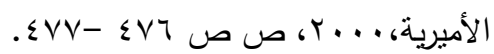

2-Della summers, et .al, "Active Study Dictionary " the Egyptian International Publishing Company _ Longman, Egypt, 1997,p.19 محمود عباس عابدين : الجودة واقتصادياتها في التربية ، دراسة نقدية " مجلة الدراسات التربوية ، المجلد )؟ (

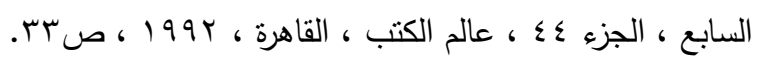


ويعرف شاك، الفعالية بأنها محصلة مكونات الأداء الكلى للمنظمة، بما تحتويه من أنشطة فنية، ووظيفية وإدارية، وما يؤثثر فى هذا الأداء من متغيرات داخلية وخارجية

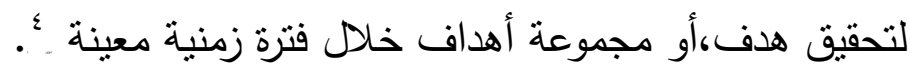
وتعرفها الدراسة الحالية بأنها تلك الخصائص التى يتميز بها الجهاز الإداري بالمدرسة بما يمتلكه من صلاحيات يعمل بها لتمكنه من إحداث تغير إيجابي لصالح المتعلم والمعلم والمجتمع المحلى بصفة مستمرة . تكنولوجيا المعلومات :

هى مجموعة المجالات المعرفية من علمية وتقنية وهندسية وإنسانية واجتماعية والإجراءات الإدارية والثقنيات المختلفة المستخدمة والجهود البشرية المبذولة فى جمع

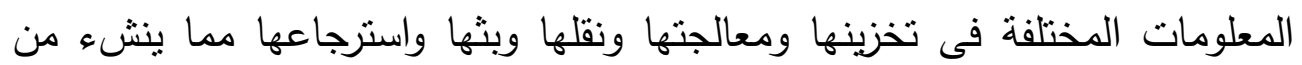
تفاعلات بين هذه التقنيات والمعارف والإنسان المتعامل معها بكافة حواسه

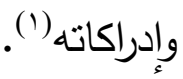

كما تعرف بأنها مجموعة الوسائل التى تسهل نقل المعلومات وتبادلها فى داخل المؤسسة أو بين المؤسسات المختلفة شاملاً ذلك جمع المعلومات وتخزينها ومقارنتها

وتحليلها (r)

وتأسيساً لما سبق وفى ضوء الدراسة الحالية يعرف الباحث تكنولوجيا المعلومات

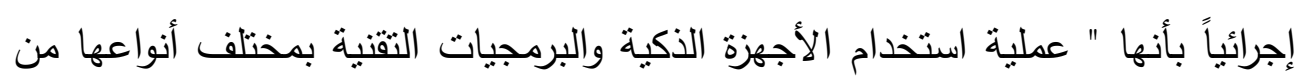

شاكر محمد فتحى : إدارة المنظمات التعليمية - رؤية معاصرة للأصول العامة ، مجموعة النيل )؛؟ (Y)

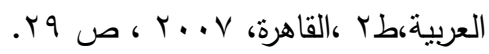

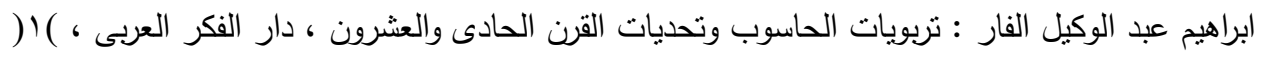

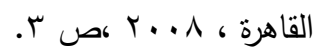

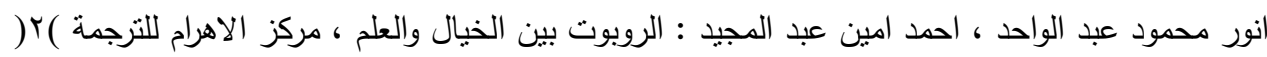

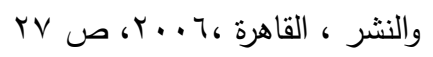


قبل الكوادر البشرية المتمثلة فى المدير والمعلم والتلميذ والموظف الإداري لتطوير وتفعيل جميع جوانب العملية التعليمية بإدارة المدرسة الابتدائية بمحافظة شمال سيناء.

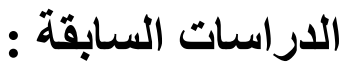

تتوعت الدراسات السابقة التى ارتبطت بموضوع الدراسة الحالية، وخصوصاً ما تتاول منها إدارة المدرسة الابتدائية، وتم ترتيب الدراسات السابقة العربية والأجنبية داخل المحاور نرتيباً زمنياً من الأحداث للأقدام، وفيما يلى أهم الدراسات وثنيقة الصلة بموضوع الدراسة الحالية، وذلك من خلال تصنيفها وفق المحاور التالية :أ- المحور الأول - دراسات تناولت إدارة المدرسة الابتدائية:

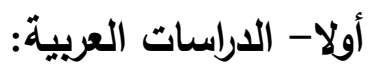

1- "تظوير إدارة المدرسة الابتدائية في ضوء بعض النماذج الإدارية الحديثة"

$(r): Y \cdot 1 \varepsilon$

هدفت الدراسة إلى التعرف على بعض النماذج الإدارية الحديثة فى مجال إدارة المدرسة الابتدائية، وأهم الصعوبات والمعوقات التى يمكن أن تواجه إدارة المدرسة الابتدائية ، وقدمت تصور مفترح لنموذج إدارى حديث فى تطوير إدارة المدرسة الابتدائية بشكل عام ومدير المدرسة ومعاونيه بشكل خاص، واستخدمت الدراسة المنهج الوصفي فى الإجابة عن تساؤلات الدراسة، وتوصلت الدراسة لمجموعة من

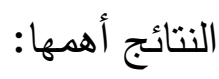
- يجب توظيف تكنولوجيا التربية في الاستفادة بها فى عملية تطبيق أساليب الإدارة المدرسية، مع مراعاة ضرورة أن تتمشى تلاك الأساليب مع الأهداف التى وضعت من أجلها لتطوير إدارة المدرسة الابتدائية. - - يجب نتويع أساليب إدارة مدير المدرسة الابتدائية، مع توظيف تكنولوجيا التعليم فى الاستفادة بها عند إجراء التطوير •

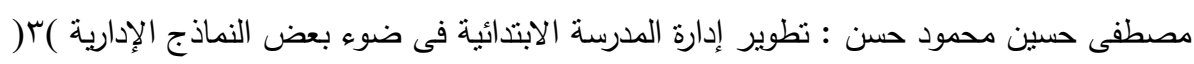

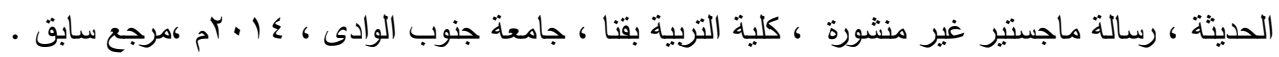


- وضع برنامج دائم لتقويم أساليب مدير المدرسة الابتدائية فى إدارة مدرسته، للوقوف على مدى صلاحيتها بما يتتاسب مع مستحدثات العصر .

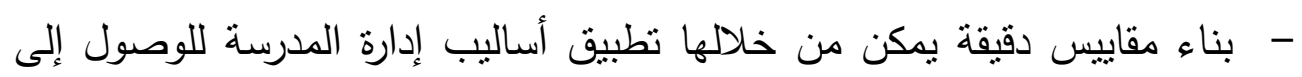
النتائج الصحيحة. r- " تظوير الألداء المدرسى بالمدرسة الابتدائية بمحافظة شمال سيناء على ضوء

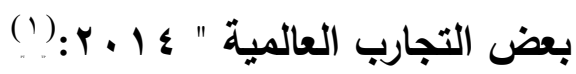
هدفت الدراسة إلى التعرف على أهم معوقات النسق الفكري للأداء المدرسى( فلسفة ومفهوم ) المدرسة الابتدائية، والتعرف على التجارب العالمية والاستفادة منها فى زيادة فاعلية الأداء المدرسى بالمدرسة الابتدائية بشمال سيناء، ومعرفة الواقع

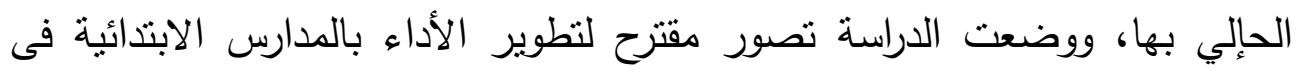

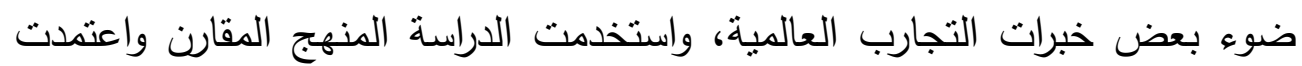
على أسلوب دراسة الحالة فى الإجابة عن تساؤلات الدراسة، وقد توصلت الدراسة ل ل لمجموعة من النتائج أهمها: - أن الإدارة الناجحة تعمل على توفير مناخ صحى للمدرسة، يعمل فيه كل فردا بارتياح وتسود فيه علاقة طيبة بين كل العاملين فى المدرسة وطلابها .

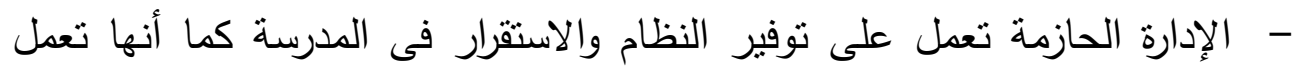
على رفع الروح المعنوية للعاملين فيها، وزيادة دافعيتهم إلى العمل وقدرتهم على الى

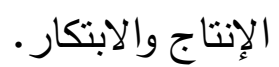
r- " تطوير إدارة مدارس التعليم الابتدائي باستخدام تكنولوجيا المعلومات

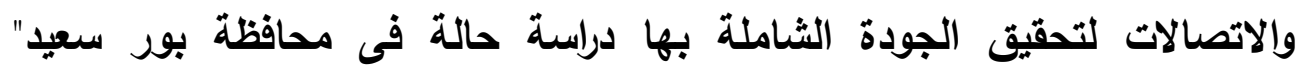
$(r): Y \cdot 1 r$

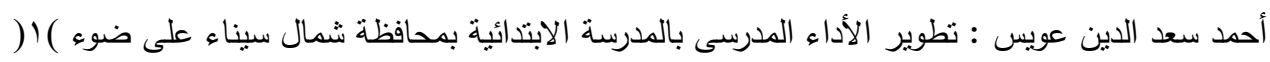

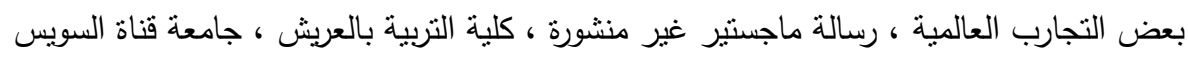
$\cdot a^{2} \cdot 1 \varepsilon 6$ 
هدفت الدراسة إلى التعرف على الواقع الحالى لتوظيف تكنولوجيا المعلومات والاتصالات فى إدارة مدارس التعليم الابتدائي ببورسعيد بالإضافة إلى التعرف على الاتجاهات العالمية المعاصرة فى استخدام تكنولوجيا المعلومات والاتصالات فى إدارة مدارس التعليم الابتدائي ووضع روئية مقترحة لتطوير الإدارة المدرسية من خلال توظيف تكنولوجيا المعلومات والاتصالات لتحقيق الجودة الثاملة، واستخدمت الدراسة المنهج المقارن واعتمدت على أسلوب دراسة الحالة في الإجابة عن تساؤلات الدراسة، وتوصلت الدراسة لمجموعة من النتائج أهمها: وجود ضعف وقصور فى استخدام تكنولوجيا المعلومات والاتصالات على المستوبين الإدارى والتعليمى بمدارس التعليم

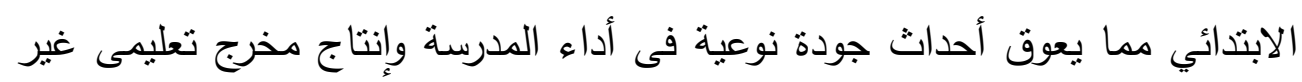
قادر على مواكبة عصر التكنولوجيا ومستحدثاتها. ع -"تطوير إدارة المدرسة الابتدائية بدولة الكويت لمواجهة تحديات مجتمع المعرفة

(') $: Y .11$

هدفت الدراسة إلى :تطوير إدارة المدرسة الابتدائية بدولة الكويت لمواجهة التحديات التى يفرضها مجتمع المعرفة عليها بهدف إكساب القدرة على مواكبة التغيرات التى يشهدها العالم اليوم، والقدرة على تحقيق النجاح والتميز، واستخدم

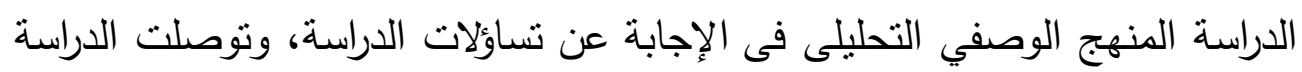
لمجموعة من النتائج أهمها: - أن إدارة المدرسة الابتدائية لابد أن تعمل باستمرار على تطوير أسلوب أدائها ـ

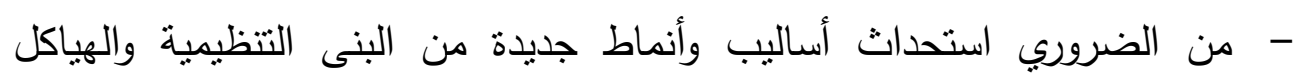

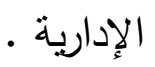

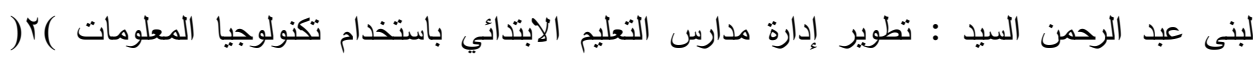
والاتصالات لتحقيق الجودة الثاملة بها دراسة حالة فى محافظة بور سعيد ، رسالة ماجستير غير منشورة ،

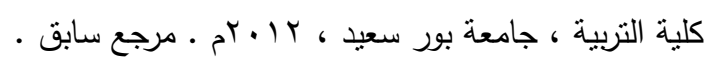

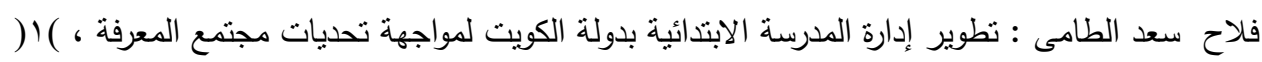

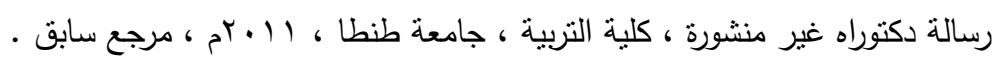


يجب على إدارة المدرسة الابتدائية بدولة الكويت الاستفادة من التكنولوجيا ومصادر

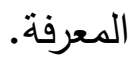

$$
\text { ثانياً- الارراسات الأجنبية }
$$

1-"اكتثاف قدرة المديرين على قيادة إصلاح جودة التدريس والتعليم في

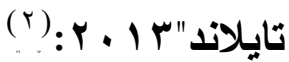

هدفت الدراسة إلى التركيز على دور مديري المدارس الثانوية والأساسية وأدائهم فى قيادة الإصلاح التربوي، خاصة بعد أن تبنت تايلاند قانوناً تربوياً طموحاً

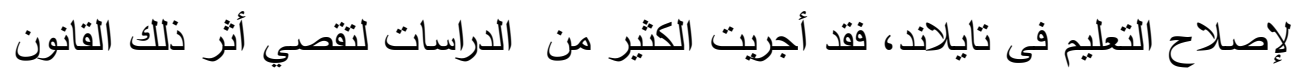
على تحسين جودة التعليم، ولتحقيق أهداف الدراسة اشتملت عينة ومجتمع الدراسة لإنة على (1900) مدير مدرسة ثانوية وأساسية، حيث تم تطبيق المقياس الوطني للإدارة

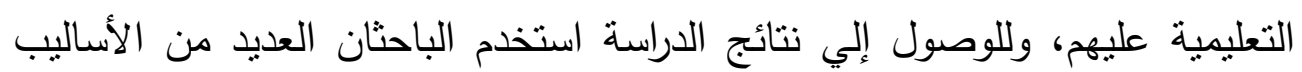
الإحصائية مثل التكرارات والمتوسط الحسابي، والوزن النسبي وغيرها، وتوصلت الدراسة لمجموعة من النتائج أهمها: - حقق مديرو المدارس مستوى متوسطاً فى إعداد رسالة المدرسة، وتطوير مناخ تعليمي إيجابي. - حقق مديرو المدارس مستوى منخفضاً فى إدارة البرنامج التعليمي. وفى ضوء النتائج السابقة، أوصت الدراسة بما يأتي:

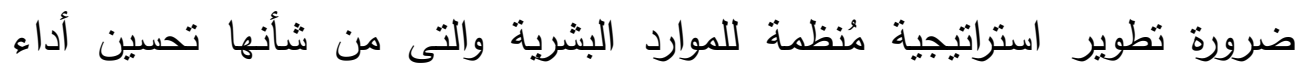
القيادات المدرسية وقدراتهم المعرفية والمهارية؛ لدعم التغيير فى التدريس والإصلاح التربوي.

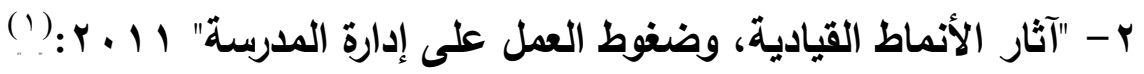

2- Hallinger, P., \& Lee, M.: "Exploring principal capacity to lead reform of teaching and learning quality in Thailand International Journal of Educational Development, Vol . 33 (4) , 2003, pp . 305-315. 
هدفت إلى إظهار العلاقة بين أساليب القيادة، وضغوط العمل على إدارة المدرسة فى دولة إيران، حيث يبدو أن الأنماط القيادية للمديرين هي من بين العوامل

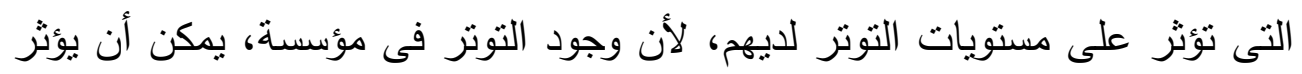
على الحياة الاجتماعية، والثخصية، والأداء الوظيفي، والصحة البدنية، والصحة النفسية، والرضا الوظيفي للأفراد، ولتحقيق أهداف الدراسة استخدم الباحث المنهج المسحي، وتكون مجتمع الدراسة من مديري مدارس الإدارة فى إيران، وقد خلصت الدراسة إلي مجموعة من النتائج، أهمها: عند زيادة معدل العلاقات بين الإدارة والعاملين، تتخفض نسبة التوتر . من النتائج الجانبية للأبحاث الأخرى تم اسنتتاج أن عوامل أخرى منل: (مستوى لإداده التعليم، والميدان التربوي، وسنوات الخدمة)، تدخلت فى خلق التوتر . وفى ضوء النتائج السابقة، أوصت الدراسة بما يأتي: الاهتمام بأختيار النمط القيادي الملائم من أجل تقليل الإجهاد، وتفادي عواقبه.

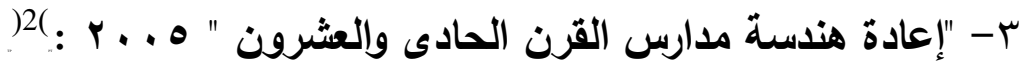
هدفت الدراسة إلي تقديم إطار مفاهيمى لمدرسة القرن الحادى والعشرين، حيث أكدت

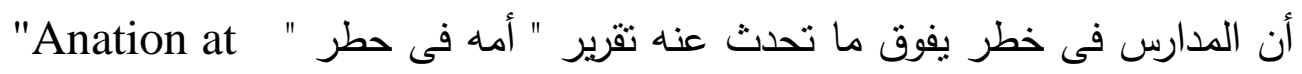
منذ أكثر من عشرين عاما، وترجع دراسة هذا الخطر إلي سيادة نماذج

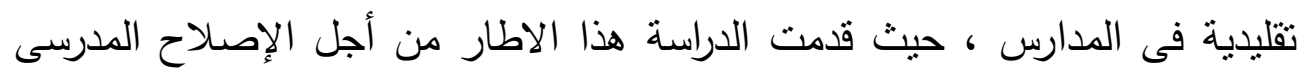

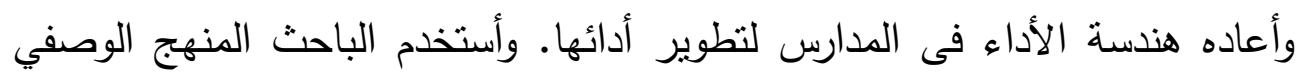
التحليلى، وتوصلت الدراسة إلى عدة نتائج منها :- نطوير المنهج المدرسى، ومما عليه طرق وأساليب التقويم وبالتإلي تطوير الاداء المدرسى، وإكساب التلاميذ خبرات

1- Vahid, Shafieipour Maziyar, Ghasemi Mohammad, Aslani The effects of leadership styles on the stress of school s directors, Procedia "leran. -Social and Behavioral Sciences 28, 2011, pp (22-86) .

2- Basset Patrick F: "Reengineering schools for 21 st century " Phi Delta kappan, VOL.(87), NO, (1) 2005. 
ذات معنى فى حجرات الدراسة وإلمام التلاميذ بنقافة منتوعة لتحسين أدائهم • وأوصت الدراسة بان تكون المدرسة ملزمة بتوفير لأداء عالئ الجودة، يمارس من خلاله التلاميذ الأنشطة ويتعلمون البحث والاستقصاء. ب- المحور الثانى - دراسات تناولت الإدارة الإلكترونية : أولا - الاراسات العربية:

1- " متطلبات تطبيق الإدارة الإكترونية بمدارس التعليم الابتدائي دراسة ميدانية

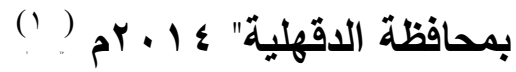
هدفت الدراسة إلى التعرف على متطلبات تطبيق الإدارة الإككترونية بمدارس التعليم الابتدائي، وأيضا التعرف على مفهوم الإدارة الإكترونية، ومراحلها و وظائفها ومجالاتها ومعوفاتها، والتعرف على أهم صفات ومميزات القائد الإلكتروني.

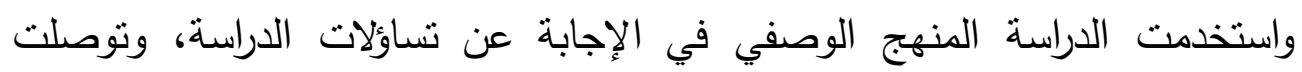
الاراسة لمجموعة من النتائج أهمها: - الصعوبات البشرية فى المدارس المعتمدة وغير المعتمدة هى واحدة ولا يوجد الهدها:

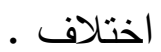

- - إن الصعوبات المادية أعلى فى المدارس غير المعتمدة عن المدارس المعتمدة. - ل العد توجد اختلافات إحصائية لمنطلبات تطبيق الإدارة الإلكترونية في المدارس المعتمدة وغير المعتمدة.

- - - ضرورة توجيه العاملين نحو تكنولوجيا المعلومات والاتصالات. - - ضرورة تدريب الموظفين لإنجاز الأعمال عبر الوسائل الإكترونية. - - ضرورة الاهنمام بالقائد الإكتروني في المدارس حيث توجيه العاملين.

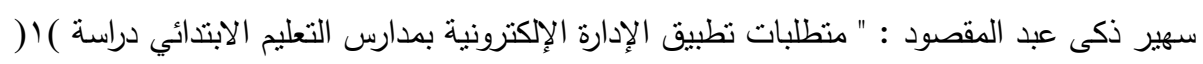

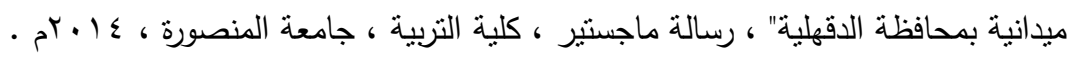


r - "تصور مقترح لتفعيل استخدام الإدارة الإلكترونية فى تطوير العمل الإدارى

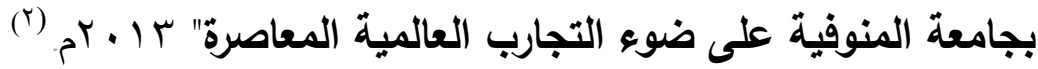
هدفت الدراسة إلى التعرف على تحليل مفهوم الإدارة الإلكترونية، ومتطلبات

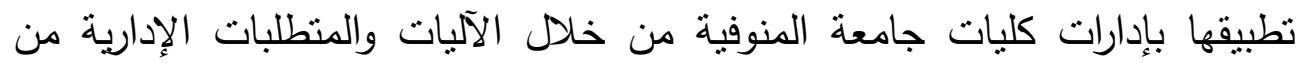
تخطيط وتتظيم وتوجيه إلكتروني، وتحديد دور الإدارة الإلكترونية فى تطوير العمل

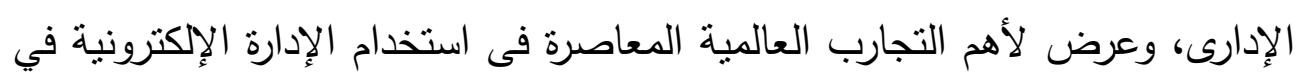

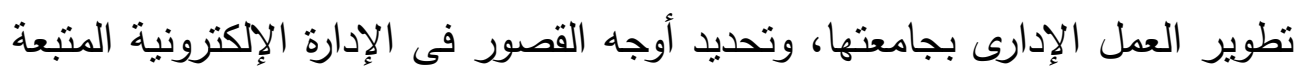
بجامعة المنوفية، وتوصلت الدراسة إلي وضع التصور المقترح فى لتفعيل استخدام

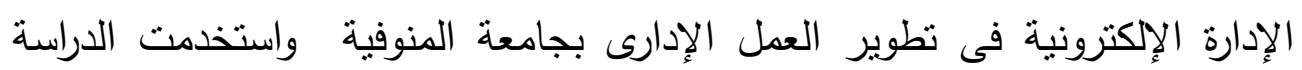
أسلوب دراسة الحالة كأحد مداخل وفنيات المنهج الوصفي للإجابة عن تساؤلات الدراسة، وتوصلت الدراسة لمجموعة من النتائج أهمها:

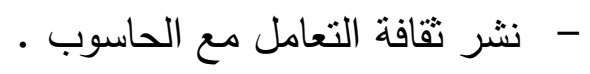
- - تلبية جميع استفسارات العملاء عبر نظامها الإلكتروني بدون تكلفة. - - تحميل البيانات والمعلومات وتحديثها عبر موقع الجامعة لكافة المتعاملين. - - العمل بروح الفريق لزيادة قدرات العاملين على تطبيق آلية العمل الإكتروني - توفير شبكة آمنة محلية (WAN) وموسعة ل ملى مستوى الكلية . r- " تظوير نظم الادارة المدرسية بمرحلة التعليم الأساسي فى ضوء برنامج مقترح

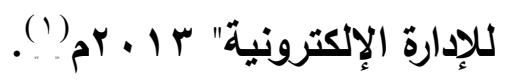

هدفت الدراسة الحالية التعرف على الإدارة الإلكترونية فى ضوء الاتجاهات الفكرية الحديثة وعلاقتها بالإدارة المدرسية، ومعرفة مفهوم الإدارة المدرسية وبنيتها

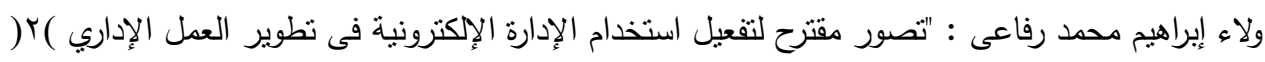

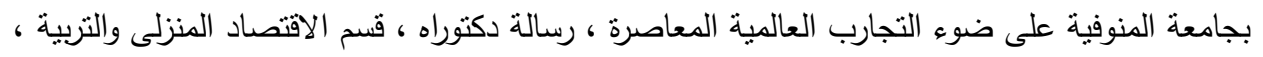

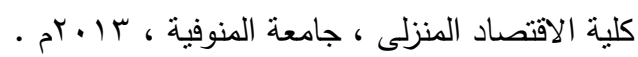

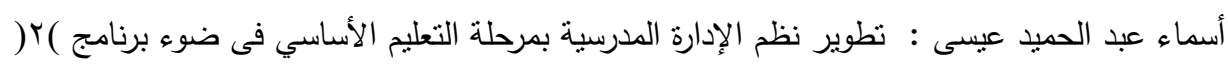

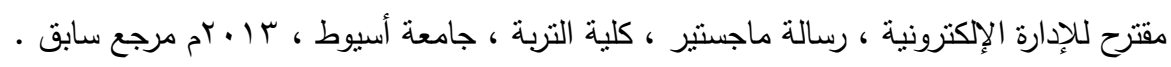


وأهدافها وفلسفتها ومبررات تطبيقها، بالإضافة إلى معرفة واقع تطبيق الإدارة الإلكترونية بمدارس مرحلة التعليم الأساسي بمحافظة أسيوط؛ بُغية الوصول إلى بلى الإسي

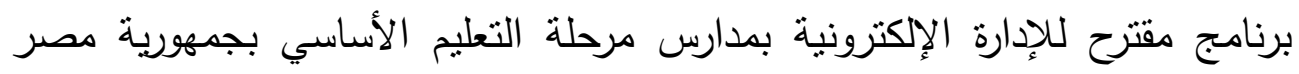
العربية. واستخدمت الباحثة المنهج الوصفي للإجابة عن تساؤلات الدراسة ، كما صممت الباحثة استبانة اشتملت على ثلاث محاور تدور حول واقع تطبيق الإدارة الإلكترونية بمدارس مرحلة التعليم الأساسي. وقد تم تطبيق الاستبانة على عينة بلغت

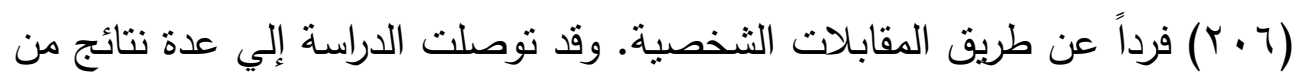
أهمها: - إجماع أفراد عينة التعليم العام على عدم توافر العديد من المنطلبات اللازمة لتطبيق الإدارة الإلكترونية بمدارس مرحلة التعليم الأساسي بالتعليم (العام ،

والخاص)

- - عدم توفير البنية التحتية والتجهيزات التقنية لتطبيق الإدارة الإلكترونية .

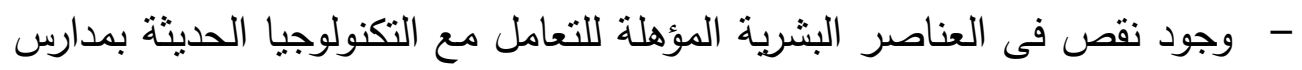
التعليم العام. - مجود معوقات إدارية تحول دون تطبيق الإدارة الإلكترونية بمدارس التعليم العام. ع -" تطوير إدارة المدرسة الثانوية العامة فى ضوء الإدارة الإلكترونية وتطبيقاتها

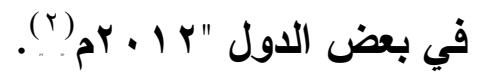

هدفت الدراسة إلى التعرف على مفهوم الإدارة الإلكترونية وأهدافها وأهميتها ووظائفها ومتطلباتها، ودورها فى تطوير الإدارة المدرسية بصفة عامة وإدارة المدرسة الثانوية العامة فى مصر بصفة خاصة،، وتعرف واقع الإدارة الإلكترونية في المدارس الإسترة الثانوية العامة فى مصر، والوقوف على واقع الإدارة الإلكترونية فى المدارس الثانوية

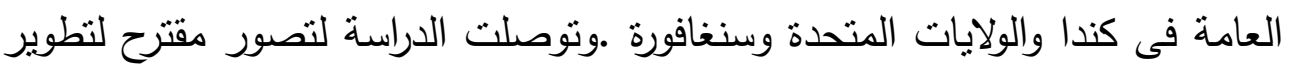

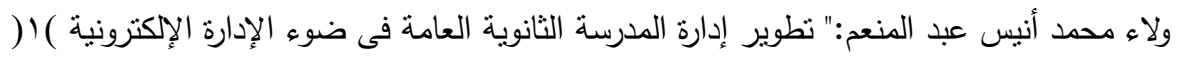

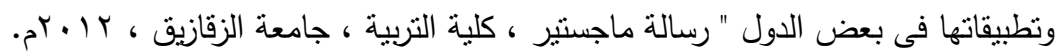


إدارة المدرسة الثانوية العامة فى مصر على ضوء تطبيقات الإدارة الإلكترونية فى بعض الدول. واستخدمت الدراسة المنهج المقارن بمدخله الوصفي للإجابة عن تساؤلات الدراسة ،وتوصلت الدراسة لمجموعة من النتائج أهمها:

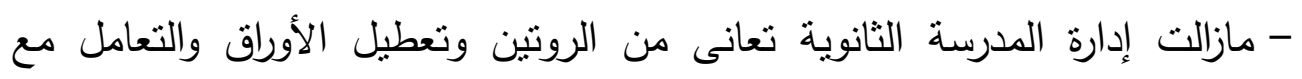
الأعمال الورقية.

- عدم اعتماد إدارة المدرسة الثانوية العامة على الوسائل التكنولوجيا الحديثة فى لـ أرسال واستقبال البيانات والملفات عبر البريد الإكتروني كبديل عن الصادر والوارد • الورقي

- ل التم حضور وانصراف العاملين بالمدرسة إلكترونياً، أنما يتم ورقياً من خله السجلات

- - تواجه إدارة المدرسة الثانوية العامة مشكلة عدم وجود عدد كافي من الفنين الذين يجدون التعامل مع الأدوات التكنولوجية.

- - تعانى إدارة المدرسة الثانوية العامة من نقص الثبكات الداخلية للحاسب داخل المدرسة، مما يعوق تبادل المعلومات إلكترونياً داخل المدرسة.

- تواجه إدارة المدرسة الثانوية العامة نقص في الإمكانيات التكنولوجية والمادية . ثانيا- الدراسات الأجنبية 1- " القيادة المدرسية وقدرتها على إدارة التكنولوجيا - الأثر والمعوقات"

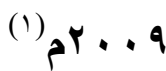

هدفت الدراسة إلى التعرف للوقوف على مدى العلاقة بين القيادة المدرسية والاستخدام الفعال للتكنولوجيا، والوقوف على مدى استخدام التكنولوجيا كوسيلة لاتخاذ القرارات الخاصة بالسياسة التعليمية المدرسية، ومعرفة كيفية وضع الأهداف وتحديد رؤية ورسالة المدرسة ونشرها بين جميع العاملين فيها، واستخدمت الدراسة المنهج

1- Andersond ,R.E and S.L. Dexter ; "Technology Leadership, Incidence and Impact ",www.Crito .Uel. Edu/tle/html/finings, Retrieved , at,20-4-2015. 
التحليلي للإجابة عن تساؤلات الدراسة، وتوصلت الدراسة إلى مجموعة من النتائج أهمها:

- جميع المدارس التى طبقت فيها الدراسة ببعض الولايات الأمريكية تتمتع بخصائص القيادة التكنولوجية. - عملية دمج التكنولوجيا بالإدارة تزبد من فعالية الإدارة المدرسية، بالإضافة إلى بـ

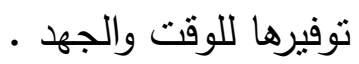

- - عملية دمج التكنولوجيا بالإدارة تزيد من تفاعل المدرسة مع بيئتها الخارجية.

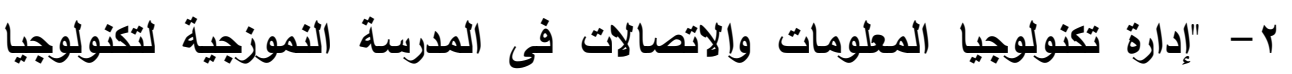

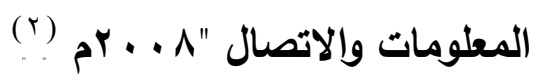

هدفت الدراسة إلى التعرف على مستوى إدارة تكنولوجيا المعلومات والاتصال

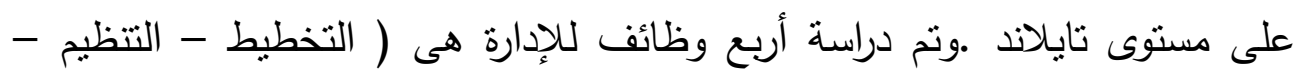
التوجيه - الرقابة )، وتم من خلال الدراسة مقارنة الوضع الراهن لإدارة تكنولوجيا المعلومات والاتصال بالمعايير القياسية لإدارة المدرسة النموذجية لتكنولوجيا المعلومات والاتصال. وتم تصميم استبانة لتحقيق أهداف الدراسة ، وتوصلت الدراسة إلى مجموعة من النتائج أهمها : - أن الوظائف الإدارية الأربع التخطيط والتنظيم والتوجيه والرقابة جيدة المستوى التهائ مقارنة بالمعايير القياسية النموذجية . - أن الإدارة التشاركية التى يشترك فيها جميع العاملين بالمدرسة شرط أساسي وجوهري لنجاح الإدارة الإلكترونية المعتمدة على التكنولوجيا. r- " روئة مدير المدرسة لدوره القيادي في دمج التكنولوجيا بمدرسته" ج +. . بم

2-Sanguankawe C.; "The Information and communication Technogy Administeration of the ICT Model School" , htt/ gotoknow.org.,23-4-2015. 1 - B. P ERSAUD; "School Administerations Perspective on thir Role in Technology Integration",Ph.D.Walden University, United States ,2006 
هدفت الدراسة إلى التعرف على رؤية مدير المدرسة لدوره القيادى فى دمج التكنولوجيا بمدرسته، والمهارات الواجب توافرها لتحقيق ذلك، والجوانب التدربيية اللازمة لتحقيق التتمية المهنية، لتصبح لدى المدير القدرة على التعامل مع المجتمع التكنولوجي، واستخدمت الدراسة المقابلات الثخصية مع عدد من المديرين للتعرف على وجهات نظرهم نحو دورهم في دمج التكنولوجيا فى العملية التعليمية. وتوصلت الدراسة إلى مجموعة من النتائج أهمها : - يوجد قصور فى دمج تكنولوجيا المعلومات والاتصال فى المدارس، وذللك لعدم مشاركة المديرين فى تصميم الدورات التدريبية الخاصة بهر. مما بيؤثر بشكل سلبى فى قيادتهم لمدارسهم فى عصر التكنولوجيا . - - ان مديرى المدارس يجيدون المهارات التكنولوجية اللازمة لإدارة البيانات وتحليلها،

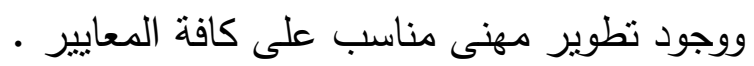
أوجه التثابه والاختلاف بين الدراسة الحالية والدراسات السابقة: اولاً أوجه التشابه التهابه

تباين متطلبات استخدام الإدارة الإككترونية وتوضيح التباين التطبيقى لآلياتها. توضيح أهمية استخدام التكنولوجيا الإدارية فى منظومة الإدارة المدرسية. توضيح مفهوم تكنولوجيا المعلومات وأهميتها وأهدافها، وتحديد كيفية تطبيقها

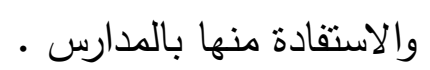

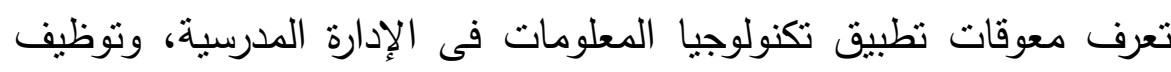
تكنولوجيا المعلومات فيها.

تعرف متطلبات التغير من الإدارة التقليدية على الإدارة الإلكترونية الحديثة .

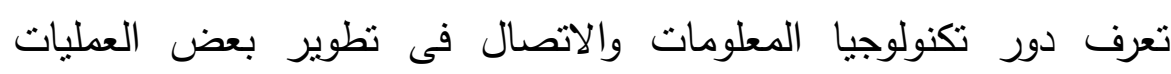

$$
\text { الإدارية فى الإدارة المدرسية. }
$$

استخدام احد أساليب المنهج الوصفي، والاسنبانة فى جمع البيانات .

ثانياً أوجه الاختلاف 
اختلفت الدراسة الحالية عن بعض الدراسات السابقة فى تتاولها أسلوب دراسة الحالة والمنهج الوصفى لوصف الإطار النظرى والميدانى من أجل وضح تصور مقترح لتحقيق فعالية إدارة المدرسة الابتدائية باستخدام الإدارة الإلكترونية بشمال سيناء.

تختلف الدراسة الحالية عن الدراسات السابقة فى الحدود المكانية حيث طبقت فى المدارس الابتدائية بمحافظة شمال سيناء . اختلفت الدراسة الحالية عن الدراسات السابقة في تتاول موضوع الدراسة حيث تسعى الدراسة الحالية إلى معرفة سبل استخدام تكنولوجيا المعلومات لتحقيق فعالية إدارة المدرسة الابتدائية بشمال سيناء، والتعرف على أهم مميزات تكنولوجيا المعلومات ، ووظائفها الهامة ومعوقات تطبيقها بالمدارس الابتدائية

تسعى الدراسة الحالية إلى وضع تصور مقترح لاستخدام تكنولوجيا المعلومات في تحقيق فعالية إدارة المدرسة الابتدائية بشمال سيناء . أوجه الإقادة من الدراسات السابقة

من خلال العرض السابق للاراسات السابقة، يمكن استخلاص بعض الاستتناجات التى قد ثقيد في وضع المقترح:

التعرف على المعوقات التى تواجه تطبيق استخدام تكنولوجيا المعلومات لتحقيق فعالية إدارة المدرس الابتدائية، وكيفية علاجها لاستمرار فعالية إدارة

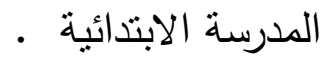

التعرف على أهمية الإدارة الإلكترونية وكيفية استغله تكنولوجيا المعلومات والاتصال وتوظيفها للاستفادة منها فى تحقيق فعالية إدارة المدرسة الابتدائية. التعرف على وظائف الإدارة الإككترونبة، وصفات القائد الإلكتروني ومفهوم القيادة الإكترونية وكيفية تطبيق الحكومة الإلكترونية فى تحقيق فعالية إدارة

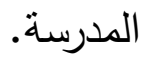

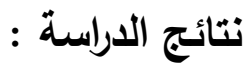


أسفر الإطارين النظري والميداني للاراسة عن عدة نتائج تتعلق باستخدام تكنولوجيا المعلومات فى تحقيق فعالية إدارة المدرسة الابتدائية بشمال سيناء، من هذه

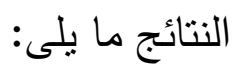

(أ) نتائج تتعلق بممارسات إدارة المدرسة الابتدائية الإكترونية المرتبطة بالتخطيط: 1 - تعبر إدارة المدرسة الابتدائية عن أهدافها الموضوعة وعن رؤيتها بوضوح

$$
\text { عبر موقعها الإكتروني. }
$$

r - قلة تحقيق إدارة المدرسة الابتدائية لرغبات المتعاملين إلكترونياً عبر موقعها.

ب- تسعى إدارة الددرسة لاستخدام التقنيات الحديثة مثل الحاسوب فى تفعيل عملية التخطيط المدرسي ولكن عملية التخطيط مركزية من قبل الوزارة مما يؤكد على أنها بعيدة عن الواقع • ع التحطيط

ع - تحاول إدارة المدرسة الابتدائية إيجاد جو من الألفة عبر موقعها من خلال تشجيع جميع العملاء من التعاون والمشاركة الفعالة بمقترحاتهم فى فعالية إدارة

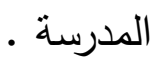

ه قليلاً ما توافر إمكانية تحميل البيانات عبر موقعها الإكتروني لجميع المتعاملين تلاميذ وأولياء أمور وعاملين بالمدرسة.

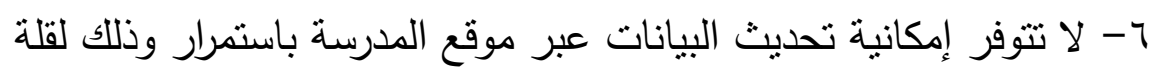
جدية التخطبط وممارسة تلك الوظيفة فى فعالية الإدارة المدرسية الإلكترونية. V - تسعى إدارة المدرسة دائما لربط التخطيط بالبيئة المحيطة وإمكانية الاستفادة من التخطيط بالمجتمع المحلى وجعل عملية التخطيط مرنه ولكن قلة نشر ثقافة الإدارة الإككترونية يحول دون تحقيق ذلك حيث التخطيط الفعال المرن به قصور بسبب سيادة مركزية التخطيط وصرف النظر عن احتياجات ومطالب البيئات المختلفة.

(ب) نتائج تتعلق بممارسات إدارة المدرسة الابتدائية الإكترونية المرتبطة

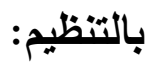


1 - مازالت إدارة المدرسة الابتدائية تعانى من الروتين والتعامل مع الأوراق، ومع الأع

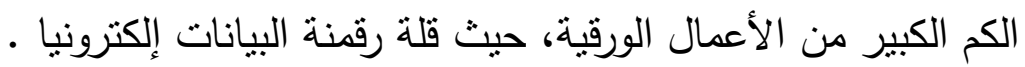
r- يوجد تتظيم إلكتروني من قبل إدارة المدرسة الابتدائية لإجراءات تسجل الدخول عبر موقعها الإلكتروني • r- يوجد بعض من الخدمات الإلكترونية المقدمة من إدارة المدرسة للتناميذ عبر موقعها منل عرض لبعض الدروس المشروحة والتتبيه بمواعيد الامتحانات و بـ التعديلات التى تتم بالجدول الدراسي. ع - قلة وجود مكتب خاص للمنسق الإلكتروني بكل مدرسة، مما يترتب عليه عدم تتظيم لمحتويات وبيانات العاملين بموقع المدرسة وضعف خدمات البوابة الخاصة بالمدرسة لا نها غير مسئولة من أخصائي محدد. ه- لا يوجد وسيلة اتصال إلكترونية بين إدارة المدرسة والجهات المختصة منل مهن الإدارة والمديرية، ضعف خاصية البريد الإلكتروني والفاكس والاعتماد على إلى المكاتبات الواردة والصادرة الورقية.

צ- يتم استخدام التكنولوجيا المتقدمة بشكل محدود في تتظيم العمليات التعليمية من خلال بث لبعض الدروس المشروحة ورفع لبعض المذكرات الخاصة بشرح المواد الدراسية عبر البوابة الإككترونية للمدرسة. V-قلة التتظيم للجدول المدرسي الأسبوعي عبر بوابة المدرسة، والإشارة لبعض الإنه التغيرات التى تحدث به أحيانا.

^- ضعف الاهتمام والتتظيم من قبل إدارة المدرسة بتجميع أكبر قدر من المعلومات ويرجع ذلك لعدم وجود منسق إلكتروني بالمدرسة، وبيروقراطية الإدارة وجمودها وقلة مواكبة الفكر الإداري المعاصر • (ج) نتائج تتعلق بممارسات إدارة المدرسة الابتدائية الإلكترونية المرتبطة بالتوجيه: ا - يتم توجيه وتوعية أولياء الأمور نحو أهمية الندوات المدرسية عبر موقع المدرسة الإكتروني. 
r- تحث إدارة المدرسة الابندائية المعلمين على استخدام أساليب تدريس إلكترونية حديثة. r- ثقوم إدارة المدرسة بالتوجيه الإلكتروني للعاملين للحصول على عملية تعليمية متميزة عبر موقعها ولكن دون تفعيل لذلك. ع - تتعامل بمرونة مع مشكلات التلاميذ الاجتماعية عبر موقع المدرسة. 0- تسعى إدارة المدرسة للعمل بروح الفريق لزيادة قدرات العاملين على تطبيق

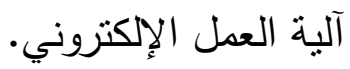
7- توظيف البريد الإلكتروني للتواصل بين المعلمين وأولياء الأمور ، ولكن دون فعالية متبادلة من الطرفين حيث يفقد جانب المتابعة والتوجيه من قبل الطرفين ـ (د) نتائج تتعلق بممارسات إدارة المدرسة الابتدائية الإلكترونية المرتبطة ولئة

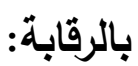
1 - تضع إدارة المدرسة آليات الرقابة والمتابعة والتحكم من بعد باستخدام تقنيات حديثة. r- يتم الضبط لعمليات الأرشفة الإكترونية وتسرب المعلومات ولكن لا تتوافر الإمكانيات

r- الافتقار لوضع برامج رقابية ضمن خطة المدرسة وتطبيق الرقابة الإككترونية. ع - لا يتوفر تقارير داخلية أو خارجية إلكترونية.

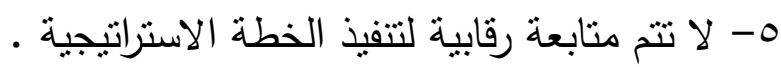
צ- لا يتم عمل وتصميم برامج رقابية إلكترونية لمساعدة العملاء عبر موقع لانع المدرسة.

V- قصور فى رفع وأرسال التقارير إلي الجهات المختصة إلكترونياً . ^- لا تصل القرارات من الجهات المختصة للمدرسة إلكترونيا بل بالبريد اليدوي الصادر والوارد. 
(ه) نتائج تتعلق بممارسات إدارة المدرسة الابتدائية الإكترونية المرتبطة

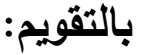

1- تساعد المعلمين على تطبيق نظام الاختبار الإلكتروني عبر موقعها. r- الافتقار لاستخدام الاختبارات الإلكترونية لتقييم التلاميذ بالمدرسة عبر موقعها

ب- ضعف تقييم المعلمين من قبل الموجهين إلكترونيا عبر موقع المدرسة.

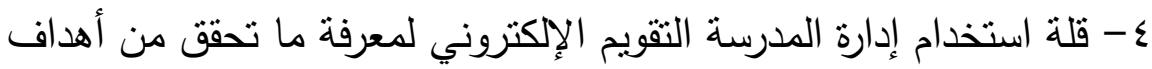

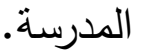

0- قصور فى استخدام إدارة المدرسة التقويم الإكتروني للوقوف على نقاط الضعف ومعالجتها.

7- تعلن إدارة المدرسة عبر موقعها الإكتروني عن أساليب التقويم المستخدمة للتلاميذ وكيفية استخدامها. V - تعمل على خلق مجتمع إلكتروني قادر على مواكبة مستجدات العصر . 1- قلة نوافر التغذية الراجعة للعاملين بها للاستقادة من الأخطاء ومعالجنها إلكترونياً.

\section{متطلبات تطبيق التصور المقترح :}

- توفير العدد الكافى من أجزة الكمبيوتز ، بحيث يتم تخصيص جهاز كمبيوتز واحد لكل

، ناميذ فى المدرسة، وأن يتم توفير جهاز خاص بكل معلم ووكيل ومدير ( ) وفصل استخدام أجهزة الكمبيوتز الموجودة فى معامل الحاسب الآلى عن الأجزة المخصصة للاستخدام الإداري بالمدرسة. - تزويد المدارس الابتدائية بالمبرمجين والفنيين المتخصصين فى صيانة الحاسبات الآليه والأجهزة المساندة لها، من ذوى الخبرة المناسبة ، وأن يكون تخصصهم حاسب لهب لهب آلى ويفضل الجامعيون منهم، بحيث يكون عملهم خاصاً بالصيانة والتركيب والثبكات والمتابعة لجميع الأجهزة الاككترونية بالمدرسة. 
- العمل على توفير العدد المناسب من الأجهزة الإككترونية الأخرى المساندة لعمل

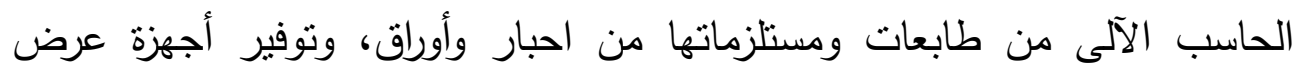

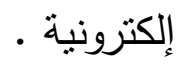
- تقديم الدعم الفنى والتقنى المستمرين لإصلاح الأعطال التى قد تحدث والإجابة عن اية تساؤلات من المستخدمين . - تخصيص متخصص الكترونى بكل مدرسة ابتدائية يسمى المنسق الإكتروني

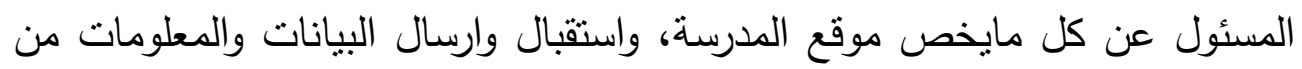
وإلى المستقيدين من بوابة المدرسة خلال ع ب ساعة . - تفعيل خدمة البريد الإككتروني الخاص بالمعلمين والتلاميذ، بحيث يتيح الفرصة

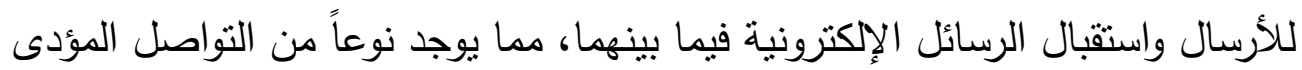
إلى زيادة دافعية التلاميذ للاراسة وزيادة قدرتهم على التفكير الابداعى

(ه) معوقات تطبيق التصور المقترح:

ا- الافتقار إلي خطط واضحة و محددة من وزارة التربية والتعليم لاستخدام تطبيقات الإدارة الإلكترونية في المدارس الابتدائية من خلال تكنولوجيا المعلومات. r- كثرة الأعباء الإدارية والمدرسية على أعضاء إدارة المدرسة الابتدائية. r- غياب القوانين والنتريعات واللوائح التى تتظم طرق تطبيق تكنولوجيا المعلومات بما فيها الإدارة الإلكترونية فى المدارس الابتدائية . ع- عدم كفاءة بعض أجهزة الحاسوب المتوفرة في المدارس الابتدائية . ه- عدم توفير المكان المناسب بالمدارس الابتدائية الذى يستوعب تقنيات الإدارة

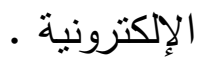

צ- النقص فى الثبكات الداخلية للحاسوب ( LAN - WAN) داخل معظم

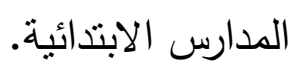
- افتقار معظم المدارس الابتدائية إلى وجود منسق إلكتروني خاص بموقع المدرسة ، بالإضافة إلى عدم وجود مختص لصيانة أجهزة الحاسوب . 1- الجهل بدور تكنولوجيا المعلومات فى تطوير العمل الإداري • 


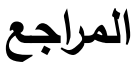

\section{اولاً - المراجع العربية}

1 - ابراهيم عبد الوكيل الفار : تربويات الحاسوب وتحديات القرن الحادى والعشرون

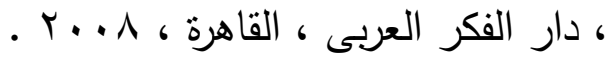

r - أحمد سعد الدين عويس: تطوير الأداء المدرسى بالمدرسة الابتدائية بمحافظة شمال سيناء على ضوء بعض التجارب العالمية، رسالة ماجستير غير منشورة

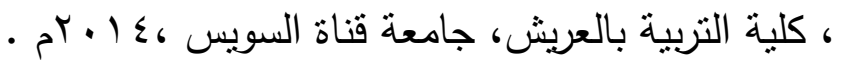
r- أسماء عبد الحميد عيسى : تطوير نظم الإدارة المدرسية بمرحلة التعليم الاساسى فى ضوء برنامج مقترح للإدارة الإلكترونية ، رسالة ماجستير ، كلية

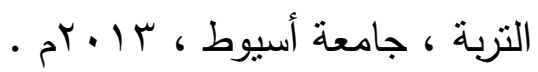
ع - السيد عبد السلام محمد : دراسة ميدانية لبعض مشكلات المدرسة الابتدائية ومواجهتها فى ضوء الفكر الإداري المعاصر ، رسالة ماجستير غير منشورة ،

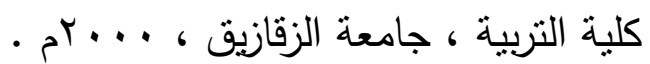
ه- انور محمود عبد الواحد ، احمد امين عبد المجيد : الروبوت بين الخيال والعلم

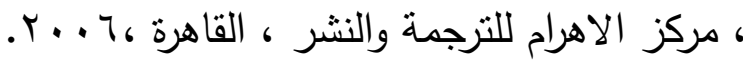
צ- جابر عبد الحميد جابر ، وأحمد خيرى كاظم : مناهج البحث في التربية وعلم النفس ، القاهرة

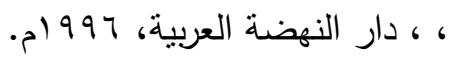

V- رأفت رضوان : الإدارة الإلكترونية، بحث مقدم إلى الملتقى الإداري السعودي

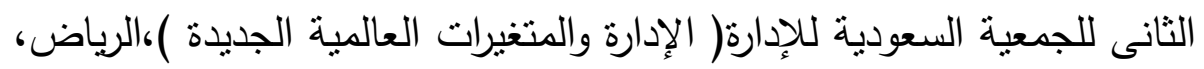

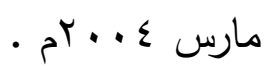

^- سهير ذكى عبد المقصود : " متطلبات تطبيق الإدارة الإلكترونية بمدارس التعليم الابتدائى دراسة ميدانية بمحافظة الدقهلية"، رسالة ماجستير، كلية

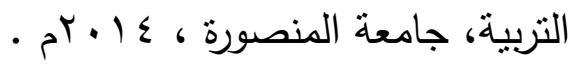

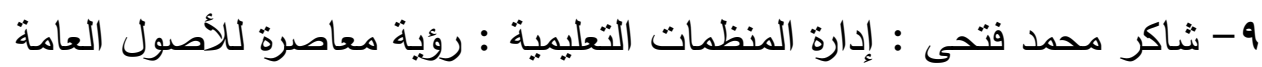

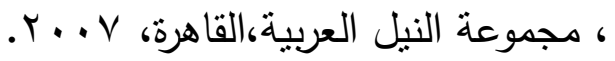


• 1 - عبد الغنى عبود وآخرون : إدارة التعليم الابتدائى فى عالمنا المعاصر ، فى د.

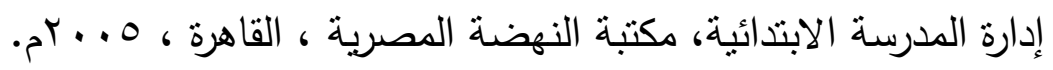
1 - فلاح سعد الطامى : : تطوير إدارة المدرسة الابتدائية بدولة الكويت لمواجهة تحديات مجتمع المعرفة ، رسالة دكتوراه غير منشورة ، كلية التربية ، جامعة

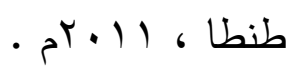
r ا كلثم محمد الكبيس : متطلبات تطبيق الإدارة الإكترونية فى مركز نظم

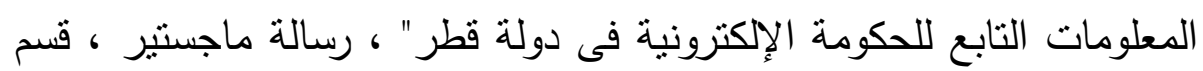

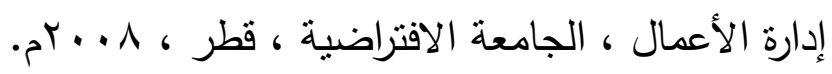
r ا-لبنى عبد الرحمن السيد : تطوير إدارة مدارس التعليم الابتدائي باستخدام

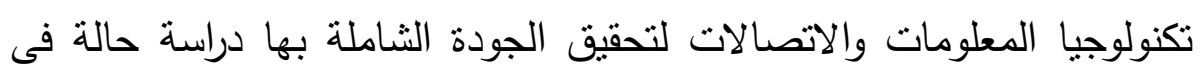
محافظة بور سعيد ، رسالة ماجستير غير منشورة ، كلية التربية ، جامعة بور

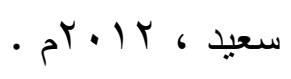

ـ ا - مجمع اللغة العربية : المعجم الوجيز ، وزارة التربية والتعليم ، القاهرة ، الهيئة

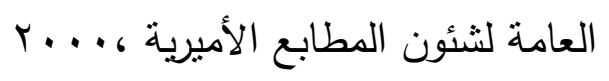

ه - محافظة شمال سيناء : مديرية التربية والتعليم ،مكتب إدارة الاحصاء ، تم

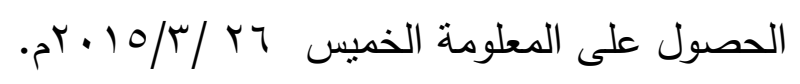

7 - 17 الدراسات التربوية ، المجلد السابع ، الجزء ؟ء ، عالم الكتب ، القاهرة ، .1994

IV - مصطفى حسين محمود: تطوير إدارة المدرسة الابتدائية فى ضوء بعض

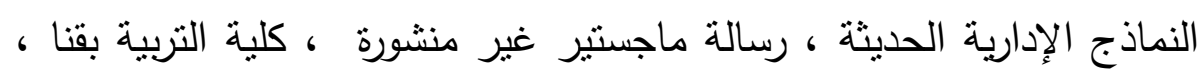

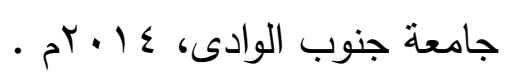

11 - مسلم محمد عليوه ومحمد أحمد عوض : الإدارة الإلكترونية في المدرسة الثانوية العامة بين الواقع والمأمول ، دراسة ميدانية على منطقة المدينة المنورة

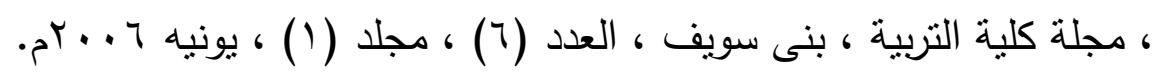


9 1 - ناهد بهجت محمد : نطوير الإدارة المدرسية فى مصر فى ضوء الفكر

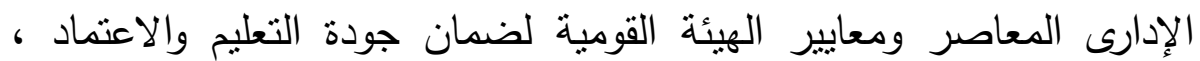

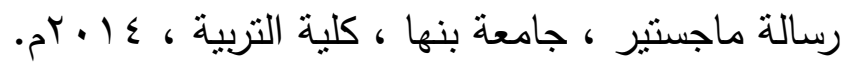

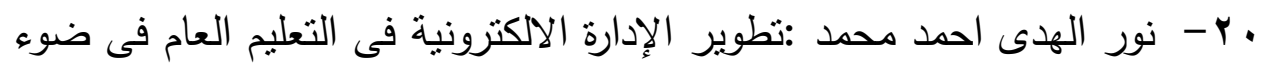

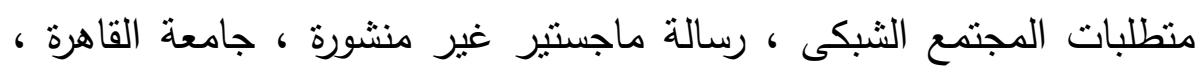

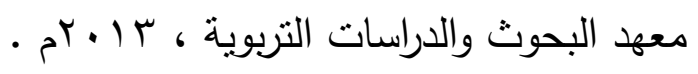

ا ب- ولاء ابراهيم محمد رفاعى : "تصور مقترح لتفعيل استخدام الإدارة الإلكترونية فى تطوير العمل الإدارى بجامعة المنوفية على ضوء التجارب العالمية المعاصرة ، رسالة دكتوراه ، قسم الاقتصاد المنزلى والتربية ، كلية الاقتصاد الهداد

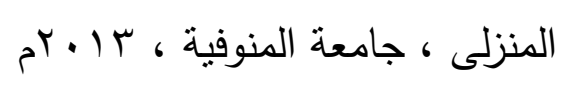

r Y - ولاء محمد انيس عبد المنعم:" تطوير إدارة المدرسة الثانوية العامة فى ضوء الإدارة الإكترونية وتطبيقاتها فى بعض الدول "رسالة ماجستير ، كلية التربية،

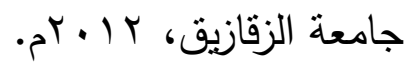

$$
\begin{aligned}
& \text { ثانيا- المراجع الاجنبية : }
\end{aligned}
$$

23- Bassett, Patrick F: "Reengineering schools for 21 st century " Phi Delta kappan, VOL. (87), NO . (1) 2005,.

24- B. P ERSAUD; "School Administerations Perspective on thir Role in Technology Integration",Ph.D.Walden University, United States ,2006.

25-Cliv Dimmock;" Manangig for Quality and Accountability in Western Australian Education" Educational Review Journal, Vol 42 , No. 2 , 2009.

26-Della summers, et .al, "Active Study Dictionary " the Egyptian International Publishing Company _ Longman, Egypt, 1997.

27-Hallinger, P., \& Lee, M.: "Exploring principal capacity to lead reform of teaching and learning quality in Thailand International Journal of Educational Development, Vol . 33 (4) , 2003, 
28-Joslyn,Owen :Managing Education,3rd,ed ,London ,Longmon Group UK Ltd. 2010.

29-R.E, Andersond and S.L. Dexter ; "Technology Leadership, Incidence and Impact ",www.Crito .Uel. Edu/tle/html/finings, html,20-4-2015.

30-Sanguankawe C.; "The Information and communication

Technogy Administeration of the ICT Model School", htt/ gotoknow.org., 23-4-2015.

31-S.N .Kitso; "The use of information Technology in Improving Decision-Making and Planning inVahid, Shafieipour The effects of leadership Maziyar, Ghasemi Mohammad, Aslani Social -Ieran."styles on the stress of school s directors Procedia and Behavioral Sciences 28, 2011.

32- N. S konars, Educating with the Internet - Using Net Resources at School and Home, Masschusetts, Charies River Media , 1999 , p.65 


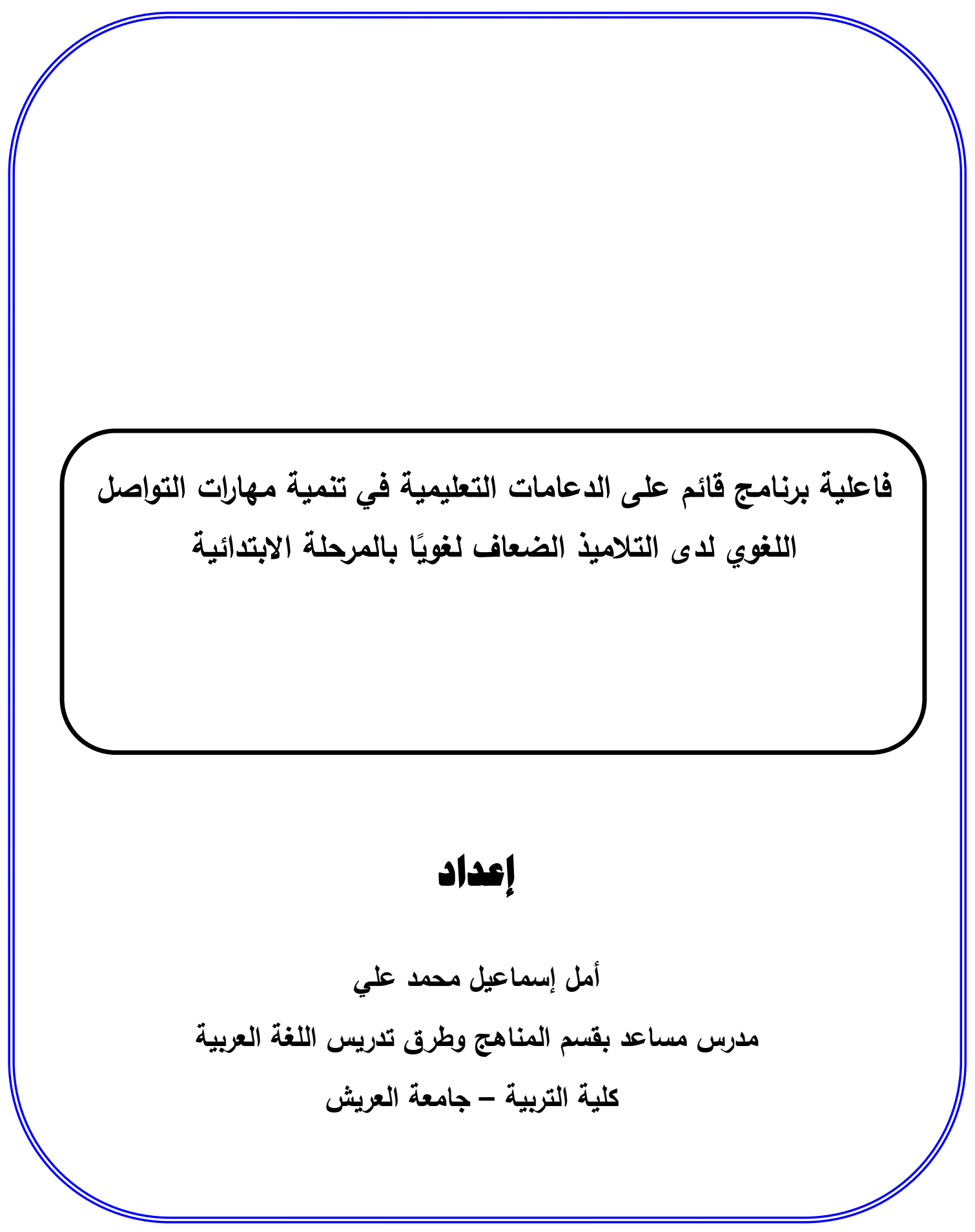




\title{
فاعلية برنامج قائم على الدعامات التعليمية في تنمية مهارات التواصل اللغوي لاى التلاميذ الضعاف لغويًا بالمرحلة الابتدائية
}

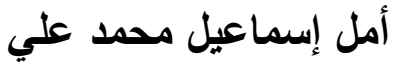

مدرس مساعد بقم المناهج وطرق تدريس اللغة العربية

$$
\text { أولاًا - المقدمةة: }
$$

تعد اللغة من أهم الظواهر الاجتماعية التي انتجها العقل البشري خلال مراحل

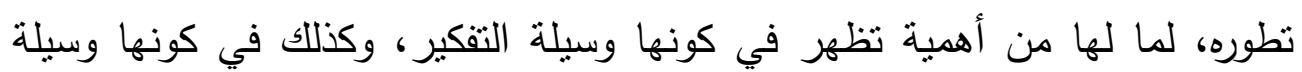

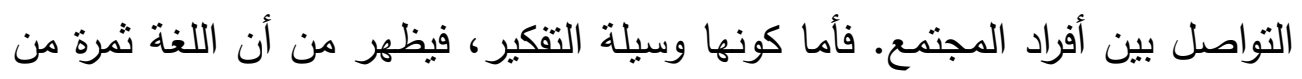

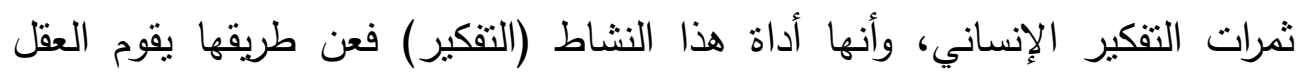
بعمليات التفكير من إدراك العلاقات وتجريد لها وتحليل واستتناج.

وأما كونها وسيلة التواصل بين أفراد المجتمع، فيظهر ذلك من أن اللغة تحقق اعتى ألخاء

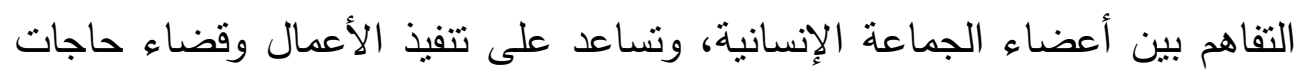
الإنسان، وتسهم في تصريف شئون المجتمع الإنساني، كما تعبر عن حاجات الإنسات الإنسان

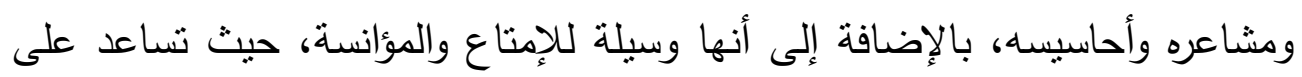

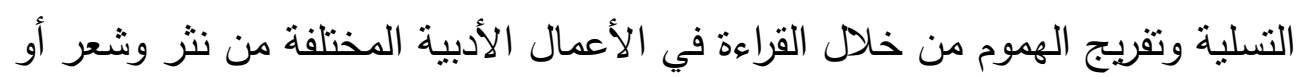

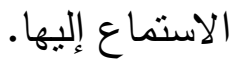

واللغة العربية هي المقوم الرئيسي للوجود العربي، ومن أقوى الروابط التي تجمع بين أبناء العروبة والدعامة الوطيدة التي يعتمد عليها العرب في الوحدة التي بسعون 


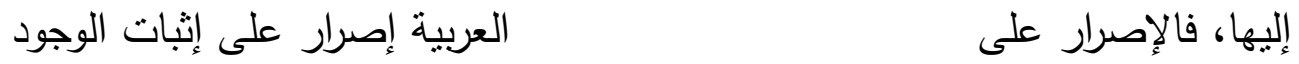

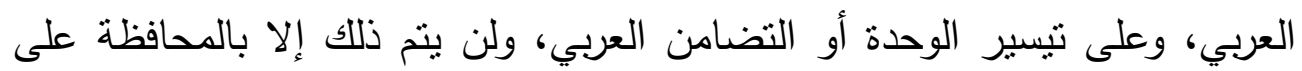

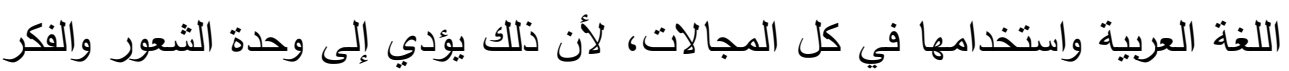

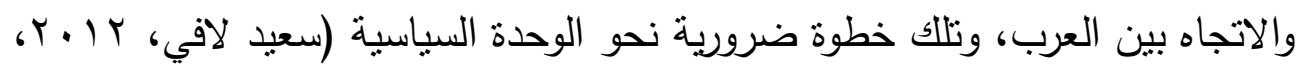
** $(r \cdot r$

وترجع أهمية التواصل اللغوي إلى أن القدرة على المشاركة والتفاعل بين

التلاميذ بعضهم بعضا وتبادل الآراء والأفكار والمعلومات حول النص المسموع تزيد من فرص البقاء والنجاح، في حين أن عدم القدرة على التواصل مع الغير يعد نقصًا

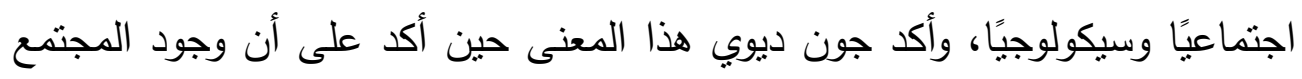
واستمراريته منوقف على النقل الثامل للعادات والأفكار والمشاعر من جيل إلى جيل هيل هيل آخر، وأن استمراريته تتم من خلال نقل الخبرات والتواصل بين الأفراد، فالناس هن يعيشون فى جماعة بفضل ما يشتركون فيه من أهداف وعقائد ومعان ومعلومات، وهم يكتسبون ذلك من خلال التواصل. ويؤكد أهمية التواصل أننا لا يمكننا أداء أو إنجاز أي نشاط أو قول أو أي جانب من الأمور بدون إجراء عملية التواصل.

* تتبع الباحثة نظام التوثيق التالي: (اسم المؤلف ثنائيًا، سنة النشر، رقم الصفحة)، ويذكر المرجع تفصيليًا بقائمة المراجع.

وهناك تقسيمات عدة للتواصل اللغوي فمنهم من قسمه إلى تواصل شفوي

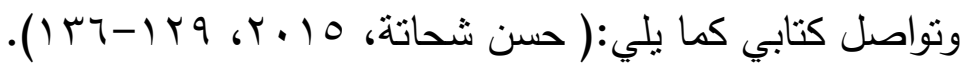

$$
\begin{aligned}
& \text { - التواصل اللغوي الثفوي: }
\end{aligned}
$$

ويعرف بأنه القدرة على استخدام اللغة المنطوقة لنقل الأفكار والمعلومات،

والمشاعر بين الأفراد وبعضهم بعضا، مما يؤدي إلى حدوث الفهم والإفهام، فالتواصل

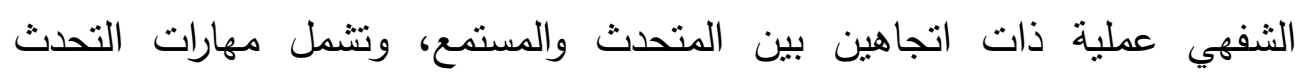
الإنتاجية ومهارة الفهم الاستقبالية، فكل من المتحدث والمستمع له وظيفة إيجابية، فالمتحدث يقوم بالتعبير عن رسالته بلغة ملائمة بينما يقوم المستمع بتفسير هذه 
الرسالة، وفي الوقت نفسه هناك عناصر أخرى تساعد المستمع على فهم الرسالة

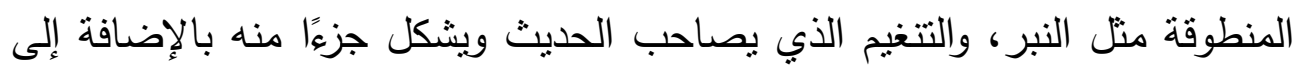
تعبيرات الوجه وحركات الجسم.

- التواصل اللغوي الكتابي:

وهو نوع من أنواع التواصل يعتمد على الكلمة المكتوبة، وتوصيل المعلومات

إلى عدد كبير من الأفراد، ويتميز بإمكانية الرجوع إليه وقت الحاجة إليه، منت : التقارير، والمنشورات، والصحف، والمجلات، والكتب، وتكون السيطرة للاتصال

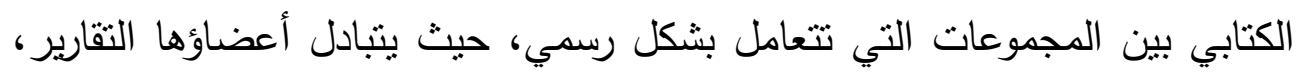
وتميل معظم المجموعات إلى استخدام التواصل الثفهي بصورة أكثر من التواصل الكتابي، فمعظم الرسائل هي التي تتنقل شفيًا.

والكتابة من أهم مهارات التواصل اللغوي، وهي من أعقد المهارات اللغوية: لأنها تتطلب قدرات أكثر مما تتطلبه مهارات اللغة الأخرى من استماع وتحدث وقراءة، ومن هنا يقول بعض اللغوبين: إن الكتابة هي جماع فنون اللغة، ومن هنا يرى البعض أن الثخص الذي يكتب كتابة جيدة هو بالتالي شخص يتوقع منه ان يقرأ جيدًا ويفهم جيذًا ما يسمع، فهي عمل لغوي دقيق براعي فيه الكاتب المقام ومقتضى الحال والفئة المستهدفة ( الجمهور) ويأتي هذا الدور من امتلاك الفرد ناصية اللغة من مهارة

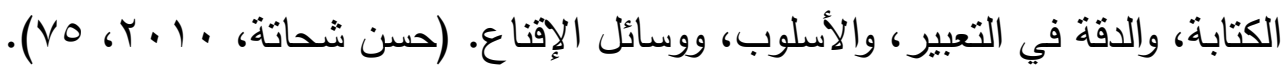

وعلاوة على ذلك فإن مقررات اللغة العربية من أهم المقررات الدراسية التي

لها تأثير كبير في شخصية المتعلم، وتقافته، وتكوينه الفكري والمعرفي، لذلك فقد أولتها النظم التربوية اهتمامًا كبيرًا، وجعلتها محورًا رئيسًا في تطوير برامجها التربوية إيمانًا منها بأهمية كتب اللغة في العملية التعليمية، وأنها الأساس في تعلم جميع المواد

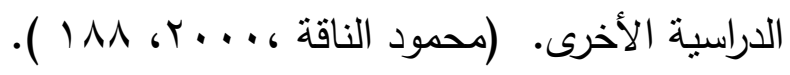


ومع ذلك فقد اقتصر الاهتمام بتدريس اللغة العربية في حصص اللغة العربية فقط، وهذا أمر خطير يتتاقض مع ما نادى به التربويون من أن كل معلم يجب عليه

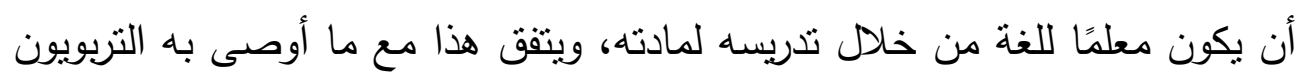
بقولهم: إن من الواجب على كل معلم لأية مادة دراسية أن يعتبر نفسه معلمًا للغة

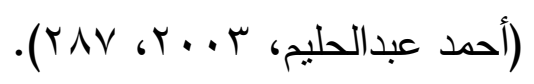

وتصنف المهارات التي ينبغى على منهج اللغة العربية إكسابها للتلاميذ إلى قسمين : الأول مهارات لغوية تتعلق بطبيعة اللغة نفسها باعتبارها أداة للتواصل الاجتماعي، والآخر مهارات دراسية نساعد الطلاب على النجاح والتفوق في المواد

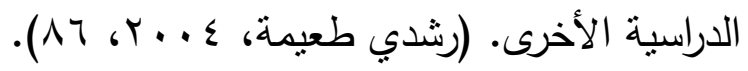

وبذلك فإن " تدريس اللغة العربية بالتعليم العام علم يستمد أسسه، وقواعده من طبيعة اللغة العربية، وخصائصها، ووظائفها، ومن الفكر التربوي، والدراسات النفسية، وفن يستمد معالمه من إبداعات المعلم، والمتعلمين " (محمد فضل الله، V .. Y r، Y).

لذا فـإن تمكين النشء مـن مهارات الكتابـة يعد هدفًا أصـيلاً في مختلف

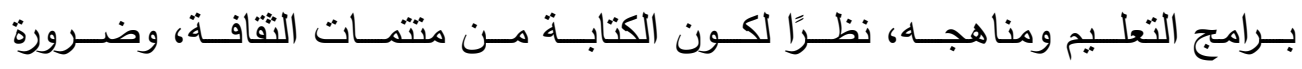
اجنماعيـة لنقـل الأفكـار والتعبيـر عنهـا، أو الوقوف على أفى أفكـار الأخـرين والإلمـام

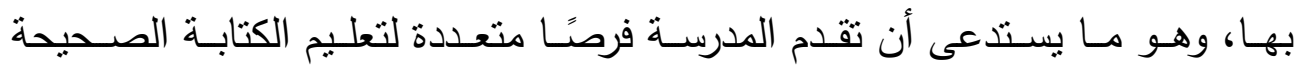

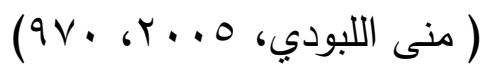

وبالتـالي فـان الوظيفـة التواصـلية للغــة تعـد أداة تمكـن التلاميـذ مـن إدراك

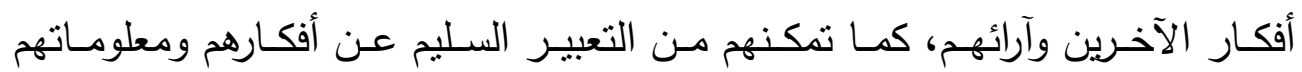

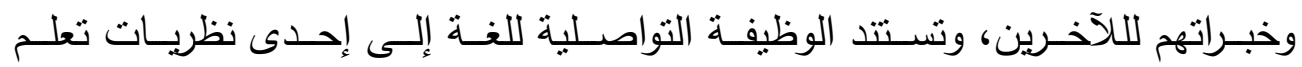

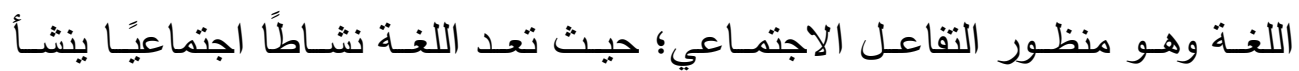
عـن الرغبــة فـي التواصـل مــع الآخـرين فـي المواقـف الاجتماعيـة التفاعليــة.

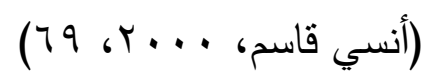


وانطلاقًا من أهمية التواصل اللغوي فقد اهتمت العديد من الدراسات التي تؤكد على أهمية اللغة والتواصل اللغوي في مختلف مراحل التعليم ومن أهم تلك

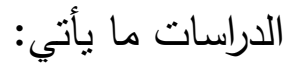

- دراسة (ثناء حسن، + . ץ) : هدفت هذه الدراسة إلى تدريس النحو بخرائط المفاهيم على تتمية مهارات الإنتاج اللغوي والاتجاه نحو المادة لدى تلاميذ الصف الأول الإعدادي.

وكان من أهم ما توصلت إليه تللك الدراسة من نتائج وجود فروق ذات دلالة إحصائية بين متوسطي درجات نلاميذ المجموعة التجريبية والمجموعة الضابطة في كل من القياس القبلي والقياس البعدي في اختبار مهارات الإنتاج اللغوي لصالح القياس البعدي.

- دراسة نيبولد (Nippold,2003):هدفت هذه الدراسة إلى مقارنة بين الأطفال المتأخرين لغويًا والأطفال الطبيعيين من نفس العمر وذلك من حيث المفردات اللغوية وما يرافقها من اضطرابات نطقية للأصوات منمنلة في ( الحذف والتشويه والإضافة ل لبعض الأصوات)

وكان من نتائج تللك الدراسة وجود ضعف في القدرة على البناء اللغوي السليم

للجملة لدى الأطفال المتأخرين لغويًا مقارنةً بالأطفال العاديين من نفس العمر . - دراسة (جبريل جبريل، V . . Y): هدفت هذه الدراسة إلى تتمية مهارات التحدث لدى تلاميذ المرحلة الإعدادية مرتفعي ومنخفضي مفهوم الذات اللغوية. 
وكان من أهم نتائج تلك الدراسة تحول بعض التلاميذ من منخفضي مفهوم

الذات اللغوية إلى مرتفعي مفهوم الذات اللغوية، وتتمية التقة بالنفس لديهم؛ نتيجة تعرضهم للبرنامج. - دراسة (قاسم البري، (1) (ب) هدفت هذه الدراسة إلى تعرف أثز استخدام الألعاب اللغوية في تتمية الأنماط اللغوية لطلبة المرحلة الأساسية.

وكثنت نتائج نلاك الدراسة عن وجود فروق ذات دلالة إحصائية عند مستوى (0 . . ) بين طلبة المجموعة التجريبية وطلبة المجموعة الضابطة، لصالح المجموعة التجريبية.

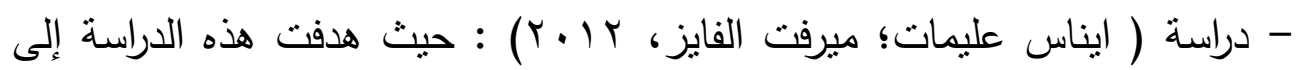
تعرف فعالية برنامج تدربيي لغوي لتتمية مهارات اللغة الاستقبالية لدى الأطفال ذوي الاضطرابات اللغوية في عينة أردنية.

وكان من أهم نتائج تلك الدراسة وجود فروق ذات دلالة إحصائية بين متوسطي درجات الذكور والإناث في تتمية مهارات اللغة الاستقبالية، حيث كانت هذه

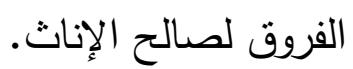

- دراسة ( جونس ونيكول) (Jones,Nicole Alissa, 2012): هدفت هذه الدراسة إلى تعرف دور المعلمين في تتمية اكساب اللغة عن طريق الفهم لدى الأطفال ما قبل المدرسة.

وكان من أهم نتائج تلك الدراسة أن تتمية اللغة الثفهية تنؤثر تأثيرًا كبيرًا على

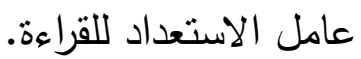


- دراسة ماكارتتي (Mccartney,E.;et.al,2013) هدفت هذه الدراسة إلى تعرف دور المعلم في تتمية المهارات اللغوية لدى التلاميذ الذين يعانون من ضعف ملحوظ في الكلام واللغة وصعوبة في الاتصال في المرحلة الابتدائية.

وكان من أهم نتائج تلاك الدراسة وجود عامل كبير على المعلم لتعليم التلاميذ ذوي صعوبات التعلم وخاصة اللغوية، وذلك من خلال التتوع فى استراتيجيات التدريس

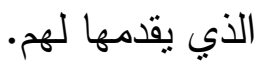

إن اسـتعمال المـتعلم للغــة لا يتعـدى أربعـة مواقـف هـي: مواقـف الاسـتماع،

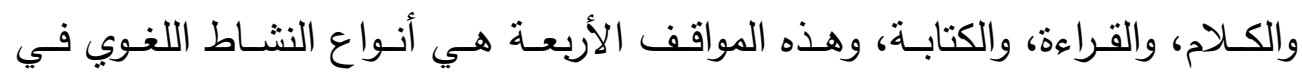

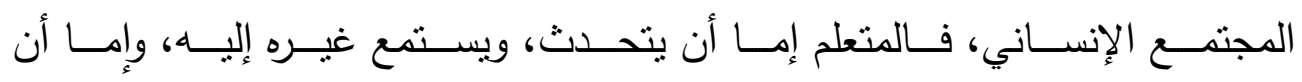

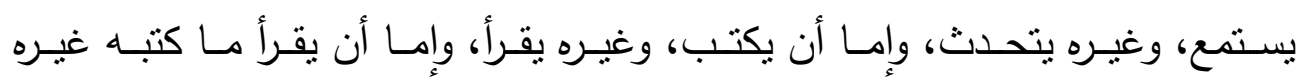

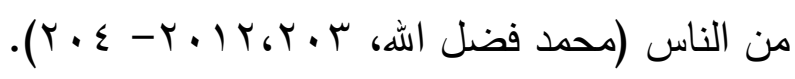

وإذا كانت للغة العربية أهمية للتلاميذ بصفة عامة، فإن أهميتها لتلاميذ المرحلة الابتدائية أهمية كبيرة؛ لذا كان من الضروري البحث عن مداخل حديثة في تدريس اللغة العربية لتلاميذ المرحلة الابتدائية تشاعدهم على توصيل أفكارهم

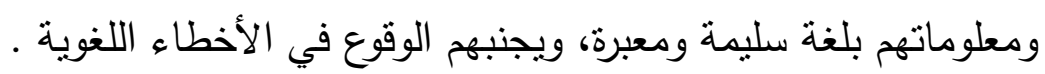

ونظرًا للتقدم العلمي، والتكنولوجي المنسارع، والتقدم المعرفي ظهرت الحاجة

إلى تغيير أساليب وطرائق التدريس، وكان لابد من إعادة النظر وتطوير أساليب جديدة وطرق متقدمة تسنتد إلى نظريات جديدة في التعلم والتعليم التي تهنم بالتلميذ نفسه، ومن أبرز النظريات الجديدة التي ظهرت في التعليم والتعلم النظرية البنائية والتي تركز على العمليات الذهنية الداخلية للتلميذ والنمو (Constructivism theory)

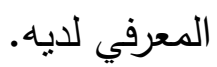


والمحور الرئيس في النظرية البنائية يتمنل في استخدام الأفكار التي تستحوذ على فكر التلميذ لتكوين خبرات جديدة، والتوصل لمعلومات جديدة، ويحدث التعلم حين تعدل الأفكار التي بحوزة المتعلم، أو تضاف إليه معلومات جديدة، أو بإعادة تتظيم ماهو موجود من أفكار لايه، أي أن عملية اكتساب المعرفة تعد عملية بنائية نشطة ومستمرة تتم من خلال تعديل المنظومات أو البنيات المعرفية للفرد من خلال آليات عملية التنظيم الذاتي( التمثل والمواعمة) وتستهدف تكيفه مع الضغوط المعرفية البيئية، فالتعلم عملية إبداع مستمرة يعيد خلالها الفرد تتظيم ما يمر به من خبرات بحيث يسعى لفهم أوسع وأثنمل من ذلك الذي توحي به الخبرات المحددة (حسام

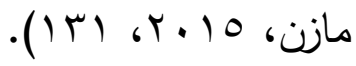

فالتعلم البنائي يكسب المتعلمين القدرة على التفكير بأنواعه المختلفة وخاصة التفكير فوق المعرفي وهو نوع من التفكير يسعى من خلاله المتعلم إلى معرفة العمليات العقلية التي يقوم بها، ونواتج هذه العمليات، ولذا فهو يسمى التفكير الواعي

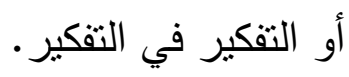

وتقوم أسس التعلم البنائي على أن التعلم عملية بنائية نشطة ومستمرة وغرضه

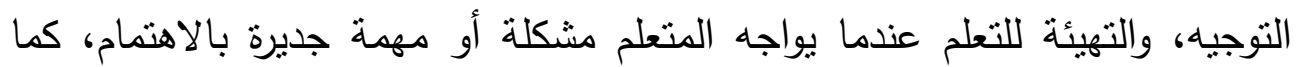
تتضمن عملية التعلم إعادة بناء الفرد لمعرفته من خلال عملية تفاوض اجتماعي مع الآخرين، كما أن المعرفة القبلية شرط أساسي لبناء التعليم ذي المعنى، وكذلك الهدف الجوهري للتعلم هو إحداث تكيف يتواءم مع الضغوط المعرفية الممارسة على خبرة

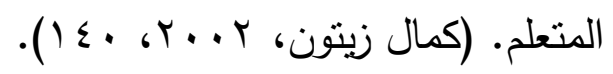

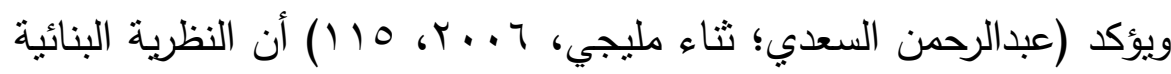

من أحدث الاتجاهات في عملية التدريس نتيجة التحول الكبير في البحث التربوي خلال العقود الثلاثة الماضية، فقد تحول التركيز من العوامل الخارجية التي تؤثر على لئ المتعلم، مثل متغيرات المعلم والمدرسة والمنهج والأقران وغيرها من العوامل، إلى 
التركيز على ما يحدث داخل عقل المتعلم حينما يتعرض للمواقف التعليمية المختلفة كمعرفته السابقة وفهمه السابق للمفاهيم، وقدرته على التذكر ومعالجة المعلومات ودافعيته للتعلم، وأنماط تفكيره وكل ما يجعل التعلم ذا معنى.

ويعد فيجوتسكي من الرواد السوفيت الذين وضعوا نظرية بنائية في التفاعل الاجتماعي، حيث اعتمد في تفسيره للنمو المعرفي والتطور الإدراكي عند المتعلم على تلى الممارسات الفعلية التي تحدث داخل التلميذ من خلال احتكاكه بالبالغين أو الأقران خارج المدرسة مما يؤدي إلى التطور المعرفي في استخدام المهارات اللغوية، فقد أولى بلى التقافة الاجتماعية للتلميذ دورًا كبيرًا في اكتساب المعرفة من خلال التفاعلات المستمرة بين الأفراد، وليس من خلال النمو العقلي، أو البنية المعرفية الموجودة في الدماغ، فالدماغ تتأثر بالتفاعلات وتتطور في فهم المواقف التعليمية المحيطة من خلال طبيعة الهية الحوار والمناقنشة بين المعلم والتلاميذ في الفصل، فالمعلم يلعب دور الوسيط ، ويوجه التلميذ تدريجيًا نحو فهم وإتقان المهمة، وهذا يعد مفتاحًا لتحفيز المتعلمين للمعرفة لـانة العلمية، ولابد من وجود دعائم تعليمية (Scaffold) او الأدوات التعليمية المساندة للتعليم ومن أهم الأدوات التي يركز علبها فيجونسكي اللغة كونها اداة للحديث وتبيانًا لما داليا يفكر به التلميذ، فهي تعمل على إخراج ما يختزنه التلميذ من معرفة بداخله، كما يركز فيجوتسكي على أهية مساعدة التلميذ خلال عملية التعلم وخاصة التلاميذ المتأخرين

وقد استخدم برونر (Bruner) و وود (wood) و روس (Ross) عام 1977

مصطلح دعامات التعلم البنائية لوصف العمليات التي من خلالها تتم مساعدة التلميذ أو ذوي صعوبات التعلم (المتأخرين لغويًا) في إنجاز مهمة ما قد لايستطيع إنجازها

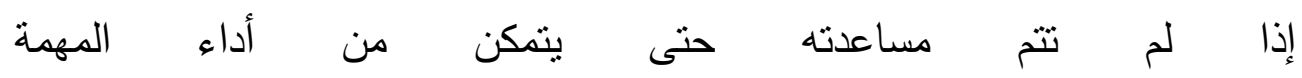
بنفسه.لاجوي (Lajoie,S.P.,2005,543).

إذًا فإن الدعامات التعليمية تعد " آلية فاعلة لمساعدة المتعلمين لتوسيع نطاق ومجالات تعلمهم لتتسع لأكبر المجالات المعرفية تعقيدًا، كما أنها تتخذ أشكالًا عديدة 
واستراتيجيات مختلفة تساعد المتعلم لتحقيق أعلى مستوى من فهم المحتوى المقدم له مثل تقديم الإرشادات، والأدوات المساعدة، كما تتمنل أيضًا في تتوع وسائل تقديم المعرفة ومفردات التدريب والأسئلة، وذلك بهدف الارتقاء بعملية التعلم من خلال هذه المهام ومراقبة تقدم المتعلم ومدى استيعابه للمحتوى المقدم. دباغ\& كيتسانتاس .(Dabbagh,N.\&Kitsantas,A., 2005,513)

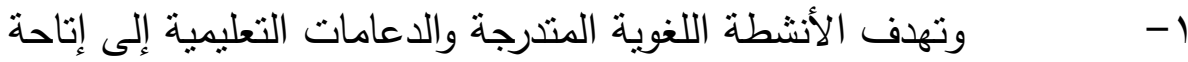
الفرصة للمتعلم لتتمية مهاراته العقلية، وقدراته الخاصة، ومن أهمها القدرة على:(نوسو (Nwosu; Azih, 2011, 37) (أزيه)

- تقويم الحقائق والمعلومات - الربط بين الأفكار والمفاهيم المختلفة. بشكل نقدي.

- مواجهة المشكلات المعقدة. - استخلاص نتائج جديدة لحل المشكلات.

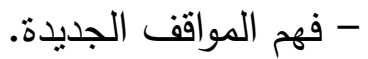
وبالتالي فإن الأنشطة اللغوية المتدرجة والدعامات التعليمية تعمل على اتاحة الدعم المؤقت للتلميذ في أثناء التعلم، بمساعدة الآخرين ومن ثم يترك لكي يكمل بقية

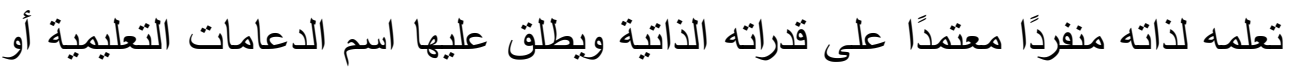
السقالات التعليمية.

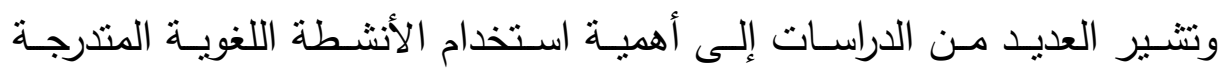
والـدعامات التعليميـة في انجـاح العمليـة التعليميـة ودعم التلميذ ومسـاندته في حل

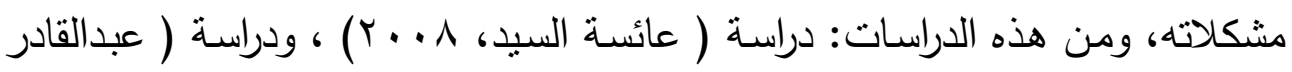
السـبد، ب ا • †)، ودراسـة هانـافين (Hannafin,2001) ودراسـة مـاكينزي (Gibson,a.,2011)، ودراسة جيبسون (mckenzie,D.,2011)

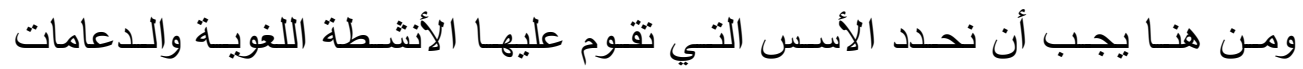

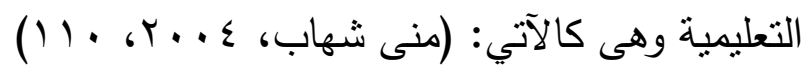


- تشجع البحث

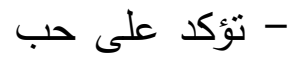

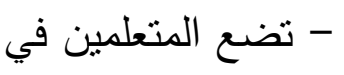

- تؤكد الأداء والفهم عند

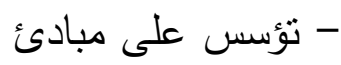

- تشجع وتقبل استقلالية ومبادرة المتعلمين. والاستقصاء للمتعلمين. - نؤكد على الدور الناقد للخبرة في التعلم. الاستطلاع. - ترتكز على التعلم التعاوني. مواقف حقيقية. - تأخذ النموذج العقلي للمتعلم في الحسبان. تقييم التعلم. - تأخذ في الاعتبار كيف يتعلم التلميذ.

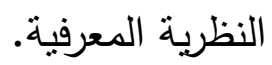
- تأخذ في الاعتبار المعتقدات والاتجاهات للمتعلمين. تجعل التعلم كعملية.

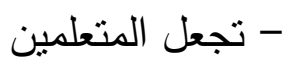
- تؤكد على المحتوى الذي يحدث التعلم. كمبدعين.

- نشجع المتعلمين على الاثتراك في المناقتة مع المعلم أو فيما بينهم. - تزود المتعلمين بالفرص المناسبة لبناء المعرفة الجديدة والفهر من الخبرات الواقعية. - تعمل على استخدام المصطلحات المعرفية مثل ( التنبؤ - الإبداع- التحليل). وتأسيسًا على ما سبق فإن الأنشطة اللغوية والدعامات التعليمية تعد مجموعة الإمدادت التي يتلقاها تلميذ الصف السادس الابتدائي عند قيامه بتتفيذ مهام تعليمية محدة خاصة بمهارات التواصل اللغوي (الثفهي والكتابي) وذللك لانجاز مهام التعلم وتحقيق الأهداف المطلوبة منه بكفاءة وفاعلية، وذللك من خلال مجموعة من

$$
\text { الإجراءات والخطوات، وهي كما يأتي: }
$$

الخطوة الأولى - تقديم الاستراتيجية التدريسية.

الخطوة الثانية - الممارسة الجماعية الموجهة. الخطوة الثالثة -تهيئة محتوى متتوع لتطبيق التلاميذ. 
الخطوة الرابعة - إعطاء التغذية الراجعة .

الخطوة الخامسة - زبادة مسؤولية التلاميذ.

الخطوة السادسة - إناحة ممارسة مستقلة لكل تلميذ.

$$
\text { ثانيًا - دواعي البحث }
$$

في محاولة من الباحثة لمعرفة جدوى استخدام الأنشطة اللغوية والدعامات التعليمية وعلاقتها بتتمية مهارات التواصل اللغوي ( القراءة والكتابة) لاى تلاميذ المرحلة الابتدائية. قامت الباحثة بمقابلة عشرة من معلمي وموجهي اللغة العربية بالمرحلة الابتدائية بمدرسة الثهيد أحمد عبد العزبز بمحافظة شمال سيناء، وذلك في

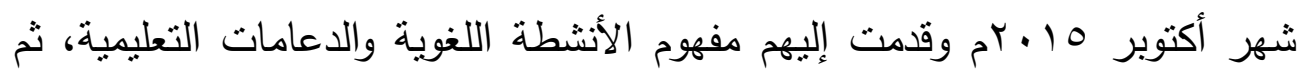
سألتهم عن جدوى استخدام هذه الإستراتيجية في تتمية مهارات التواصل اللغوي التهات القراءة والكتابة) لدى تلاميذ المرحلة الابتدائية. - ذكر المعلمون أنهم يطلبون من التلاميذ في حصة اللغة العربية كتابة أحدابله الموضوعات، وأن ليس هناك إستراتيجية منبعة في تعليم الكتابة. - كما أكد غالبية المعلمين والموجهين في إجاباتهم على أن مهارات التواصل فيله اللغوي لبعض تلاميذ المرحلة الابتدائية متدنية من حيث ضحالة الأفكار وعدم ترابطها وانتشار الكلمات العامية والأخطاء الأسلوبية والنحوية.

- كما ذكر المعلمون والموجهون في البداية أنهم لم يطبقوا هذه الإستراتيجية

$$
\text { الجديدة رغم أهميتها في تتمية المهارات اللغوية. }
$$

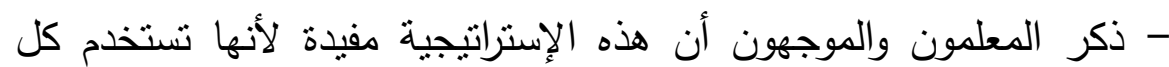

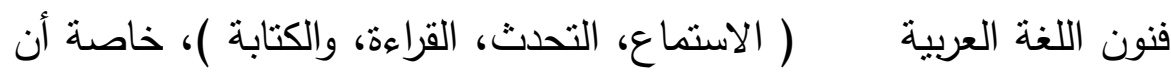
هذه الإستراتيجية ستساعد في أن يكون التواصل الثفهي والكتابي كمنتج هي المحصلة النهائية لدراسة اللغة العربية في المرحلة الابتدائية. كما قامت الباحثة بإجراء دراسة استطلاعية في شهر نوفمبر 10 ــ بمدرسة الثهيد أحمد عيدالعزيز بمحافظة شمال سيناء، بهدف تعرف مدى تمكن التلاميذ الضعاف لغويًا بالصف السادس الابتدائي من اتقان مهارات التواصل اللغوي (القراءة، 
والكتابة) حيث تم حصر أعداد التلاميذ الضعاف في اللغة العربية والحاصلين على

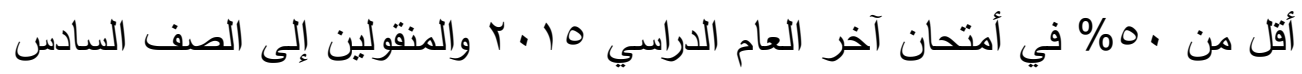

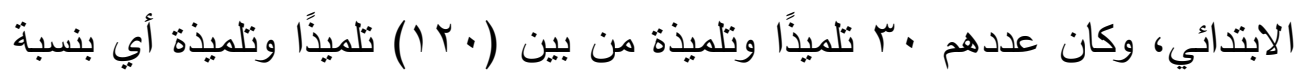
هץ\%، حيث قامت الباحثة بتطبيق اختبار استطلاعي في مهارات القراءة والكتابة، وأسفرت نتائج الاختبار عن مجموعة من النتائج أهمها: ضعف التلاميذ في مهارتي

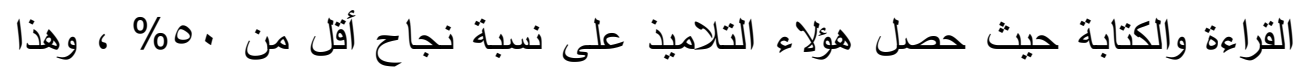
يرجع إلى عدم وجود إستراتيجية حديثة نقوم على تدريب هؤلاء التلاميذ على مهارات التواصل اللغوي في القراءة والكتابة.

كما أن الباحثة تتبعت الدراسات السابقة فوجدت أن الدراسات التي تتاولت

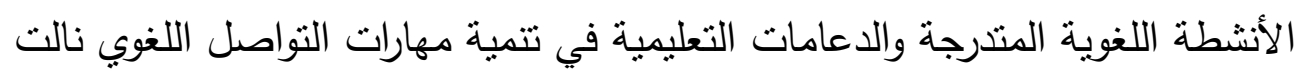
نصيبًا ضئيلاً في تعليم مهارات اللغة العربية في المرحلة الابتدائية. ثالثًا - تحديد المشكلة: تحددت مشكلة الدراسة في " ضعف تلاميذ الصف السادس الابتدائي لمهارات التواصل اللغوي (القراءة والكتابة)، كما أن ميدان تعليم اللغة العربية في المرحلة الابتدائية يفتقر إلى استخدام إسترتيجية جديدة هي الأنشطة اللغوية المتدرجة

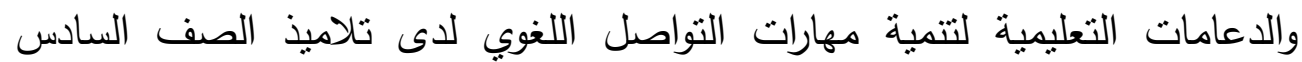
الابتدائي الضعاف لغويًا. وللتصدي لحل هذه المشكلة يحاول البحث الحالي الإجابة عن السؤال الرئيس الآتي : - n ما فاعلية برنامج قائم على الأنثطة اللغوية المتدرجة والدعامات التعليمية في تتمية مهارات التواصل اللغوي لدى التلاميذ الضعاف لغويًا الصف السادس الابتدائي؟ ويتقرع من هذا السؤال الرئيس الأسئلة الفرعية الآتية: 
ا ـ ما مهارات التواصل اللغوي في القراءة والكتابة المناسبة لتلاميذ الصف

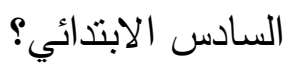

r. ما أسس بناء برنامج في الأنشطة اللغوية المتدرجة قائم على الدعامات التعليمية لتتمية مهارات التواصل اللغوي في القراءة والكتابة؟ r. ما فاعلية البرنامج المقترح في تتمية مهارات التواصل اللغوي في القراءة والكتابة لدى التلاميذ الضعاف لغويًا بالصف السادس الابتدائي؟

$$
\text { رابعًا - أهداف البحث: }
$$

يهذف البحث الحالي بصفة أساسية إلى تتمية مهارات التواصل اللغوي (قراءة وكتابة) لدى تلاميذ الصف السادس الابتدائي الضعاف لغويًا، وذلك بواسطة برنامج مقترح في الأنشطة اللغوية المتدرجة قائم على الدعامات التعليمية.

\section{خامسًا - أهمية البحث: يفيل هذا البحث في:}

1-نزويد معلمي اللغة العربية بالمهارات اللازمة للتواصل اللغوي وكذلك باستخدام إستراتيجية الدعامات التعليمية. r- تحسين تدريس مهارات اللغة العربية لتلاميذ المرحلة الابتدائية. r- استخدام اختبار تحصيلي وبطاقة ملاحظة في الحكم على مستوى التلاميذ في مهارات التواصل اللغوي. ع-رفع مستوى الأداء اللغوي لتلاميذ المرحلة الابتدائية من خلا إمدادهم بمهارات لغوية منكاملة من خلال البرنامج. 0- فتح المجال أمام دراسات أخرى تتعلق بمقررات اللغة العربية بجميع المراحل التعليمية المختلفة تقويمًا، وتطوبرًا ، ونتاولاً في جوانبها المختلفة. 4- مساعدة الباحثين لإجراء بحوث عديدة في مجالي المهارات اللغوية وإستراتيجية الدعامات التعليمية. 
سادسيًا - حدود البحث:

يقتضي البحث الحالي على الحدود الآتية:

r-الحدود العلمية: بعض مهارات التواصل اللغوي في القراءة والكتابة التي تحظى بموافقة ، ^\% فأكثر من آراء المحكمين.

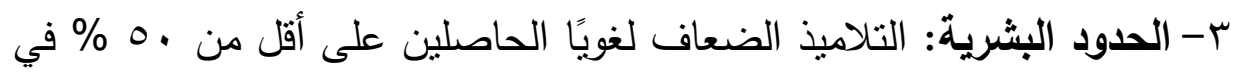
امتحان اللغة العربية في الصف الخامس الابتدائي بمدرسة الدويدار الابتدائية بحدائق القبة محافظة القاهرة.

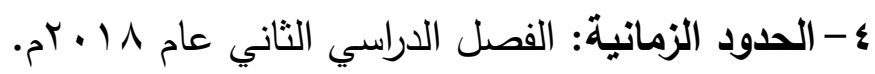

\section{سابعًا - فروض البحث:}

يحاول البحث الحالي التثبت من مدى صحة الفروض الآتية:

1 يوجد فرق ذو دلالة إحصائية عند مستوى 0 .. · بين متوسطات الدرجات

على مهارات القراءة ككل لدى مجموعة البحث في القياس القبلي عنها

$$
\text { في القياس البعدي لصالح القياس البعدي. }
$$

ץ- يوجد فرق ذو دلالة إحصائية عند مستوى ه .. • بين متوسطات الدرجات

على مهارات القراءة كل مهارة على حده لدى مجموعة البحث في القياس القبلي عنها في القياس البعدي لصالح القياس البعدي. ب- يوجد فرق ذو دلالة إحصائية عند مستوى هـ. الدرجات على مهارات الكتابة ككل لدى مجموعة البحث في القياس القبلي عنها في القياس البعدي لصالح القياس البعدي. ع- يوجد فرق ذو دلالة إحصائية عند مسنوى 0 . . بين متوسطات الدرجات على مهارات الكتابة كل مهارة على حده لدى مجموعة البحث في القياس القبلي عنها في القياس البعدي لصالح القياس البعدي. ه- يوجد ارتباط موجب دال بين مهارات القراءة ومهارات الكتابة لدى تلاميذ الصف السادس. 
צ-توجد فاعلية لبرنامج الأنشطة اللغوية المتدرجة القائم على الدعامات التعليمية في تتمية مهارات التواصل اللغوي في القراءة والكتابة. V- V- V التعليمية بالكفاءة، حيث يحصل .9\% فأكثر من التلاميذ على 9 \% فأكثر من الدرجة الكلية في مهارات القراءة وفي مهارات الكتابة.

$$
\text { ثامنًا- منهج البحث: }
$$

يعتمد البحث الحالي على منهجين من مناهج البحث التربوي: ا. المنهج الأول: هو المنهج الوصفي الذي يهتم بيحث الظاهرة، وهي مهارات التواصل اللغوي من حيث القراءة والكتابة لدى تلاميذ الصف هوب السادس الابتدائي الضعاف لغويًا. r. المنهج التجريبي: لتدريس البرنامج المقترح وتحديد مدى فاعليته في التيا. تتمية مهارات التواصل اللغوي.

$$
\text { تاسعًا - إجراءات البحث: }
$$

يسير هذا البحث في الخطوات الآتية: ا- تحديد قائمة بمهارات التواصل اللغوي في القراءة والكتابة المناسبة للتناميذ الضعاف لغويًا بالصف السادس الابندائي من خلهل: أ- مسح الدراسات والبحوث السابقة والكتابات الأدبية في مجال التواصل اللغوي. ب- - عمل استبيان بمهارات التواصل اللغوي وعرضه على مجموعة من المحكمين لتعديله. ج-تتبع ما جاء في وثيقة المعايير والمؤشرات الصادرة عن الهيئة القومية لضمان

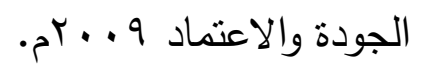

د- تحديد الوزن النسبي لهذه المهارات في الأانشطة اللغوية المتدرجة قائم على الدعامات التعليمية. 
r-تحديد أسس بناء برنامج قائم على الدعامات التعليمية لتتمية مهارات التواصل اللغوي في القراءة والكتابة من خلاء:

أ-دراسة أبعاد الأنشطة اللغوية والدعامات التعليمية والإجراءات المرتبطة بهما، وإعداد قائمة بخطواتهما.

ب- توظيف مهارات التواصل اللغوي في القراءة والكتابة التي حظيت بنسبة •^^ مأكثر من آراء المحكمين، وإعدادها في قائمة نهائية. r-بناء برنامج في ضوء الأسس السابقة وتقسيمه إلى في صورة دروس مع مراعاة إعداد: أ-بناء دليل للمعلم قائم على هذاء البرنامج. ب- إعداد أوراق عمل بمهارات التواصل اللغوي للتلاميذ في ضوء البرنامج السابق.

ج- عرض البرنامج بدروسه على مجموعة من المحكمين لتعديله قبل تتفيذه.

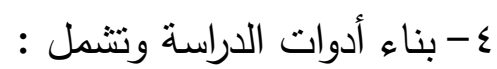

أ- إعداد قائمة بمهارات القراءة الملائمة لتلاميذ الصف السادس الابتدائي والتأكد من صدقها وثباتها. ب-إعداد اختبار تحصيلي في مهارة الكتابة في ضوء المهارات السابقة والتأكد من صدقه وثباته. 0- اختيار مجموعة الدراسة من بين ناميذ الصف السادس الابتدائي، وتهيئتهم لدراسة البرنامج المقترح. 7- تطبيق الاختبار قبليًا على المجموعة. - V تقديم البرنامج المقترح للمجموعة باستخدام دليل معلم وأوراق عمل. 1- إعادة تطبيق الاختبار على أفراد مجموعة البحث. 9- التوصل إلى النتائج الكمية ومعالجتها احصائيًا وتفسيرها ومناقشتها. • 1- تقديم التوصيات والمقترحات في ضوء النتائج التي تم التوصل إليها. عاشرًا - مصطلحات البحث: 
ا-الأنشطة اللغوية المتدرجة: gradual linguistic activities النشاط اللغوي يعنى ما يقوم به المتعلم برغبته من ممارسات مرتبطة باللغة

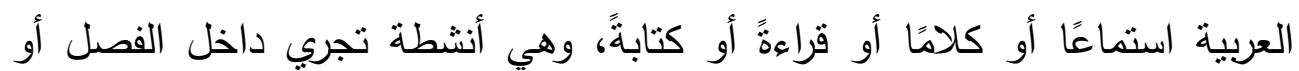
خارجه، وتمنل أوجهًا ومظاهر لسبل واحدة يكمل بعضها بعضًا، وهذه قوامها تهيئة مواقف مناسبة، وإتاحة الفرص لتحقيق تعلم سوى عن طريق خبرات يمارسها المتعلم

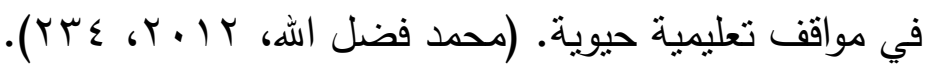

وتعرف أيضًا الأنشطة اللغوية بأنها هي: الوسائل الفعالة التي يستخدمها المعلم وتستعين بها المدرسة الحديثة في تحقيق أهداف تعليم اللغة العربية، حيث أصبح مسلمًا به أن اللغة لا تعلم بقواعد وقوالب منطقية منظمة وحدها، بقدر ما يتم تعليمها

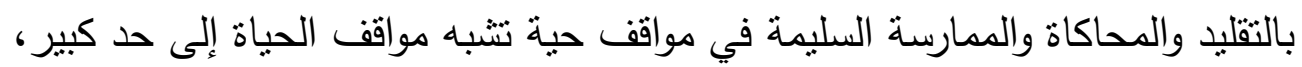
وهنا تأتي الأنشطة اللغوية بمجالاتها المتتوعة لتمتل أفضل الوسائل لبلوغ هذه الغايات لتئه لورات

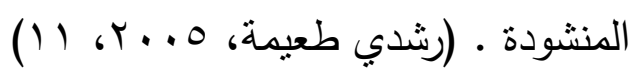

وتعرف إجرائيًا في البحث الحالي: نشاط يقوم به التاميذ الضعاف لغويًا بالصف السادس الابتدائي لنتمية مهاراتهم اللغوية في نشاطات لغوية معدة ، ويتم فيها منح التلاميذ للتدرب على تلك المهارات.

\section{r - الدعامات التعليمية: Instructional scaffolding}

يعـرف برونـر الـــعامات التعليميـة بأنهــا " عبــارة عـن عمليـة تـتنم عـن

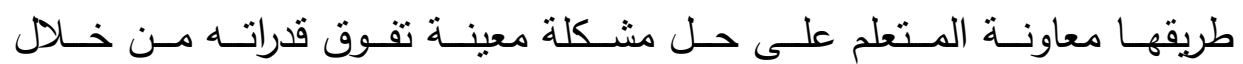

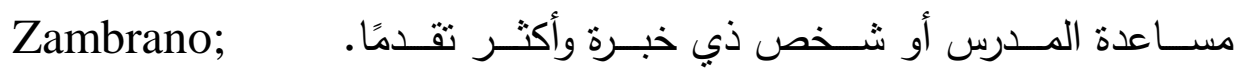

(Noriega, 2011,53)

أما إيراسين وولسن (Airasian\& walsh) فقد عرفاها على أنها الكيفية التي يتم من خلالها اكتساب العمليات العقلية، وتطويرها واستخدامها. (كمال زيتون، $(r) T, r \ldots r$ 
وتعرف إجرائيًا في البحث الحالي: بأنها إستراتيجية تدريسية تساعد تلاميذ الصف السادس الابتدائي الضعاف لغويا على حل المشكلات اللغوية لديهم، والتركيز على التعلم النشط وتشجيع المنافسة بينهم.

\section{r- مهارات التواصل اللغوي:مات}

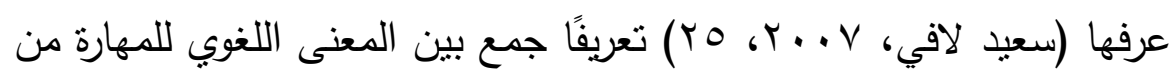
حيث إنها أداء العمل في دقة وسرعة والتعريف الاصطلاحي للمهارة اللغوية حيث عرفها بأنها " أداء لغوي يتميز بالدقة والسرعة، سواء أكان هذا الأداء القرائي أم الكتابي.

والاتصال اللغوي هو عملية تفاعل بين فرد وآخر، او بين مجموعة من الأفراد ومجموعة أخرى، تشتهدف المشاركة في خبرة للتعديل في سلوك الأفراد. (محمد فضل هل

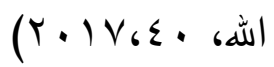

وتعرف إجرائيًا في البحث الحالي: بأنه العملية التي يستطيع من خلالها تلميذ الصف السادس الابتدائي نقل مشاعره وأفكاره ومفاهيمه وخبراته ومعلوماته باستخدام اللغة المقروءة والمكتوبة.

\section{- نتائج الدراسة وتفسيرها:}

توصل البحث الحالي إلى النتائج الآتية:

ا ـ قائمة مهارات التواصل اللغوي في القراءة والكتابة لتلاميذ الصف السادس الابتدائي. وقد تضمنت أثنتى عثرة مهارة ، حصلت كلها على وزن نسبي • ٪ \% فأكثر لاى المحكمين. r. قائمة أسس بناء برنامج في الأنشطة اللغوية المتدرجة قائم على لى

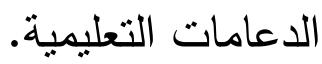


r. برنامج مقترح في الأنشطة اللغوية المتدرجة قائم على الدعامات التعليمية لتتمية مهارات التواصل اللغوي (القراءة والكتابة). ع. يوجد فرق ذو دلالة إحصائية عند مستوى ا |... بين منتسطات الدرجات على مهارات القراءة ككل لدى مجموعة البحث في القياس القبلي عنها في القياس البعدي لصالح القياس البعدي. 0. يوجد فروق ذو دلالة إحصائية عند مستوى إ.... بين متوسطات الدرجات على مهارات القراءة كل مهارة على حدة لدى مجموعة البحث في القياس القبلي عنها في القياس البعدي لصالح القياس البعدي.

7. يوجد فرق ذو دلالة إحصائية عند مستوى ا . ... بين منتسطات الدرجات على مهارات الكتابة ككل لدى مجموعة البحث في القياس القبلي عنها في القياس البعدي لصالح القياس البعدي. V. يوجد فرق ذو دلالة إحصائية عند مستوى I +.,. . بين متوسطات الدرجات على مهارات الكتابة كل مهارة على حدة لدى مجموعة البحث في القياس القبلي عنها في القياس البعدي لصالح القياس

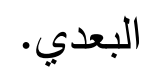
^. يوجد ارتباط موجب دال بين مهارات القراءة ومهارات الكتابة لدى تلامبذ الصف السادس. 9. توجد فاعلية لبرنامج الأنشطة اللغوية القائم على الدعامات التعليمية في تتمية مهارات التواصل اللغوي في القراءة والكتابة.

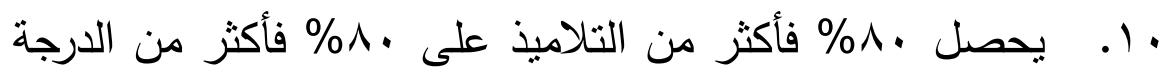
الكلية في مهارات القراءة ومهارات الكتابة. إن هذه النتائج الإيجابية للبحث الحالي تشير إلى أن: 
ا ـ البرنامج المقترح الذي طبق على تلاميذ الصف السادس الابتدائي لتتمية مهارات التواصل اللغوي في القراءة والكتابة قام على أساس الأنشطة اللغوية والدعامات التعليمية وهذا يعني أن ممارسة التلاميذ لهذه الأنشطة التواصلية والدعامات التعليمية التي حصلوا عليها من خلال البرنامج المقترح كانت ممارسة فاعلة ظهرت في أداء التلاميذ القرائي والكتابي. r. تتظيم دور المعلم حيث استثار المتعلم ووجهه وأرشده، وأنه نشاط نقل التلاميذ من حالة الانفعال إلى مواقف التفاعل والإيجابية. r. إن البرنامج المقترح الذي تعرض له التلاميذ زهاء شهرين نفذ في

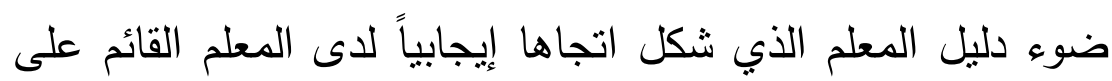
التدريس لمجموعة البحث في مدرسة الدويدار الابتدائية الرسمية بمنطقة حدائق القبة بمحافظة القاهرة - وكان هذا الاتجاه الإيجابي نحو ممارسة النشاط اللغوي، وحيث ربط بين ممارسة النشاط اللغوي سواء في التمثيل أو الإذاعة والصحافة المدرسية، أو الأنشطة المتنوعة التي تحقق بواسطة النقاش والحوار . ع. كانت الأنشطة اللغوية حقيقية قامت على أسس التخطيط الجيد والتتفيذ الجيد والتقويم الجيد، ظهر ذلك مرتبطاً ارتباطا وثيقا بمهارات التواصل اللغوي في دروس القراءة والكتابة والأنشطة الصفية والأنشطة غير الصفية معا. ه. نتائج البحث الحالي الإيجابية تشير إلى أن ممارسة الأنشطة اللغوية والدعامات التعليمية التي حصل عليها التلاميذ من زملائهم ومن التن التهني المعلم ومن التقويم قد حقق التغذية الراجعة. 
7. لاحظت الباحثة ان ممارسة النشاط في البرنامج المقترح لم تكن غاية في حد ذاتها لتعميق ممارستها لدى التلاميذ، بل هي وسيلة مهمة لتحقيق اهداف محددة من أهمها: توجيه التلاميذ ومساعدتهم على اكتساب المهارة اللغوية في القراءة والكتابة بالممارسة والتوجيه. توسيع خبرات التالاميذ باستخدام مهارات القراءة والكتابة في المناشط اللغوية باستخدام استراتيجية كل اللغة، أي توظيف تلك بك المهارات في جميع فروع اللغة العربية. تتمية الاتجاه نحو القراءة والكتابة من خلال الحرية المنظمة التي تتيح ممارسة الأنشطة المختلفة على نحو ينمي فيهم الاعتماد على النفس، ويكسبهم القدرة على المبدأة والحوار وإبداء الرأي والتفسير والتعليل.

إتاحة الفرص المتتوعة أمام التلاميذ للاتصال بالبيئة ومناشط الحياة اليومية، والتعامل معها لجعلهم أكثر اندماجا بمجتمعهم

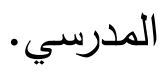

إكساب التلاميذ القدرة على الملاحظة والموازية والعمل والدقة من خلال أنشطة الإذاعة المدرسية والتثثيل والصحافة بأنشطنها المتتوعة.

V. ويعتبر ممارسة الأنشطة اللغوية المتتوعة مصدر تعاون بين التلامبذ، وتوسيعا لمجال التفاعل بينهم وبين المعلم، وغرساً للتقة في نفوس التلاميذ وأداء الواجبات والتكليفات. ^. والجدير بالذكر أن ملاحظات الباحثة أثثاء قيام المعلم بالتدريس تشير إلى ان التلاميذ كانوا يستمتعون بالحوار والمناقثات وتحديد 
الكلمات والقراءة الحرة، واستخدام اللغة العربية الفصحى في التفاعلات والمداخلات داخل الفصل . 9. إن توزيع المهارات اللغوية للقراءة والكتابة في البرنامج المقترح تم حسب خطة زمنية حققت العدالة في الوقت المخصص للتدريب على المهارات كل مهارة لغوية على حدة ، وحيث كانت المراجعة تتم في الأسبوعين الرابع والثامن، لتنبيت المهارات التي سبق أن درسها التامبذ عبر ثناثة أسابيع سبق فترة المراجعة. • 1. وقد لوحظ أن المراجعة يتم التدريب فيها على نصوص لغوية ومواقف لغوية وأنشطة لغوية جديدة غير التي سبق أن تعرض لها التلاميذ في فترات إكساب التلاميذ لمهارات التواصل اللغوي. وقد كان للتقويم البنائي المرحلي أثثاء فترات التدريس أثر واضح في تحسين اكتساب التلاميذ للمهارات اللغوبة، حيث كان المعلم يعيد الثرح والمناقثة والتدريب وتدعيم الإجابات الصحيحة بالإثابة والتعزيز اللفظي الفوري. أضف إلى ذلك أن التلاميذ قد مارسوا أنشطة لغوية وتدعيمات لغوية من قبل الزملاء والمعلم وكلها كان مشابها لما ثم في أسئلة التقويم النهائي، حيث حقق التلاميذ انتقال أثر التدريب. 11. ذكر المعلم القائم بالتدريس للباحثة أنه كان يبدأ مع التلاميذ الحصة بإعلان أهداف التدريس ووضع خطة للعمل الجماعي من خلال تقسيم التلاميذ إلى مجموعات صغيرة (V-0) تلاميذ، وأن كل مجموعة كانت تتعاون داخليا في وضع إجابة للأسئلة اللغوية وتتافس خارجيا مع المجموعات الأخرى. وأن المعلم كان بشارك 
التلاميذ في تحديد الأهداف التي تحققت في الحصة والتي لنم تتحقق ، وأن مناقثة الأخطاء اللغوية كانت تصوب جماعيا من قبل

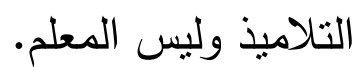
r ا. أكد البرنامج المقترح على التوجيه الفردي والجماعي سواء كان التوجيه عن طريق حل أمثلة وتدريبات أو تكليفات منزلية يقوم التلاميذ بانجازها ثم تتاقش داخل الفصل في الحصة التالية ـ أضف إلى ذلك أن التلاميذ كانوا يختارون النشاط حسب ميولهم، حيث يختار كل مجموعة من التلاميذ نشاطاً يمارسونه داخل الحصة وتحت إثراف المعلم، وغايته إتقان مهارات التواصل اللغوي في القراءة والكتابة.

\section{- توصيات البحث ومقترحاته: ا}

التوصيات هي التي تأخذ بالنتائج إلى حيز التطبيق العملي، وذلك بذكر النتيجة تعقبها التوصية، ويتم عرض ذلك في الآتي:

1- تم بناء قائمة بمهارات التواصل اللغوي، وتتكون من ست مهارات القراءة، ومثلها للكتابة. ولتفعيل هذه النتيجة بمكن الأخذ بالآتي: توظيف هذه المهارات في دروس القراءة ودروس الكتابة في الصف السادس الابتدائي، بحيث يتم توعية المعلم بهذه المهارات، وبناء النصوص اللغوية في ضوئها، والتركيز عليها في تقديم الأنشطة لئم اللغوية والأسئلة والتدريبات. r- تم التوصل إلى برنامج مفترح في الأنشطة اللغوية المتدرجة قائم على الدعامات التعليمية، ولتفعيل هذه النتيجة بمكن استخدام هذا 
البرنامج مع دليل المعلم في تحسين أداء التلامبذ الضعاف في تعلم مهارات الاتصال (القراءة والكتابة) كما بتم في هذا البرنامج على أنماط الأنشطة اللغوية وأنماط الدعامات التعليمية الوظيفية والعملية

$$
\text { والاستراتيجية. }
$$

r- تم التوصل إلى التلاميذ الضعاف في التواصل اللغوي في القراءة قد تحسن أداؤهم في هذا التواصل، سواء على مستوى مهارات القراءة ككل أو على مستوى كل مهارة من مهارات القراءة كل على حدة، ولتفعيل هذه النتيجة يمكن القيام بالأتي: أ- توظيف المعلم للأنشطة الصفية واللاصفية التي تم استخدامها في البرنامج الحالي، وكذلك الدعامات اللغوية لمواجهة التلاميذ ذوي التحصيل المنخفضة في القراءة. ب-تضمن كتاب اللغة العربية للصف السادس الابتدائي هذه الأنشطة والجعامات التعليمية عن طريق تتويع مستويات النصوص اللغوية وتدريباتها بتتوع مستوى التحصبل اللغوي التواصلي وتقديم البرنامج الحالي للتلاميذ الضعاف وإعداد برنامج آخر قائم على الإثراء للمتفوقين لغويا. ج- إعداد برامج للأنشطة الصفية واللاصفية للتلاميذ ذوي الضعف اللغوي التواصلي في القراءة. ع- تم التوصل إلى أن التلاميذ الضعاف في التواصل اللغوي في الكتابة قد تحسن أداؤهم في هذا التواصل سواء على مستوى مهارات الكتابة ككل أو على مستوى كل مهارة من مهارات الكتابة كل على حدة، ولتفعيل هذه النتيجة يمكن القيام بالآتي: 
إعداد دليل لمعلم اللغة العربية القائم على التدريس للتلاميذ ذوي الضعف اللغوي التواصلي في الكتابة يستقيد من البرنامج الحالي ومن دليل المعلم لرعاية هؤلاء التلاميذ.

مساعد معلم اللغة العربية في تحديد التلاميذ ذوي التحصبل المنخفض في الكتابة عن طريق استخدام الاختبار التحصيلي في الكتابة.

بناء حقيبة تعليمية للتلاميذ الضعاف في التواصل اللغوي الكتابي وفق ما تم التوصل إليه في البرنامج المقترح ودليل المعلم وأدوات البحث الحالي. 0- تم التوصل إلى أنه يوجد ارتباط موجب دال بين مهارات القراءة ومهارات الكتابة لدى تلاميذ الصف السادس الابتدائي، ولتفعيل هذه النتيجة يمكن تدريب التلاميذ على القراءة باعتبارها مدخلاً لتحسين الكتابة، وبمعنى آخر فإنه يتوجب أن يقرأ التلامبذ ما يكتبون وأن يكتبوا ما يقراؤن. צ- تم التوصل إلى أنه توجد فاعلية لبرنامج الأنشطة اللغوية القائم على الدعامات التعليمية في تتمية مهارات التواصل اللغوي في القراءة والكتابة ولتفعيل هذه النتيجة يمكن تطبيق هذا البرنامج في تعليم القراءة والكتابة لتلاميذ الصف السادس باستخدام دليل المعلم.

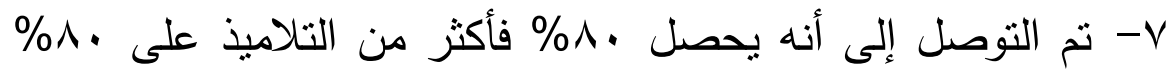
فأكثر من الدرجة الكلية في مهارات القراءة ومهارات الكتابة، ولتفعيل هذه النتيجة يمكن توعية المعلمين بهذا البرنامج القائم على الأنشطة المتنوعة التي تتمي مهارات القراءة والتي تتمي مهارات الكتابة والدعامات التعليمية من المعلم ومن الزملاء مع زيادة فترات التدريب 
على الكتابة الحرة والكتابة الموجهة وكذللك على القراءة المكثفة في الكتاب المدرسي والقراءة الموسعة عبر الانترنت وعبر أنشطة مثتوعة صفية وغير صفية. r - مقترحات البحث

يمكن القيام بدراسات علمية مرتبطة بمجال البحث الحالي، ومن أهمها: بناء وثثية بمعايير ومؤثرات التلاميذ ذوي التحصيل المنخفض في التواصل اللغوي ككل. إعداد برنامج مقترح في الذكاءات المتعددة لمواجهة الضعف في التواصل اللغوي لدى تلاميذ الصفوف الأخيرة من المرحلة الابتدائية. إعداد معلم للتلاميذ الضعاف في التواصل اللغوي بصفة عامة في ضوء الكفايات اللازمة لهذا المعلم. بناء برنامج مدمج للتلاميذ الضعاف في التواصل اللغوي قائم على الوسائط المتعددة الالكترونية والورقية. إعداد بطارية اختبارات ومقاييس وبطاقات ملاحظة لتشخيص الضعاف في التواصل اللغوي لاى تلاميذ المرحلة الابتدائية. 


\section{- المراجع - - 1) -

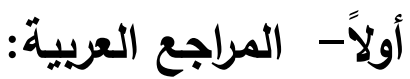

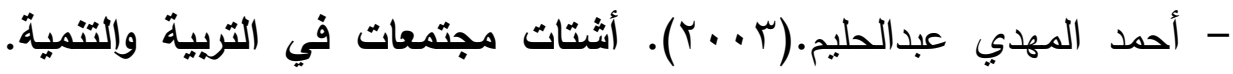

$$
\text { القاهرة : دار الفكر العربي. }
$$

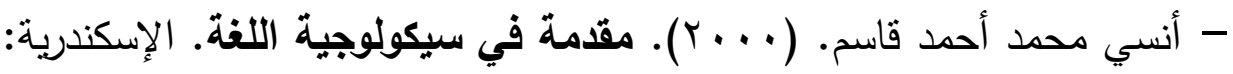

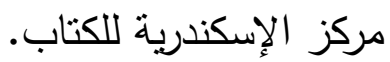

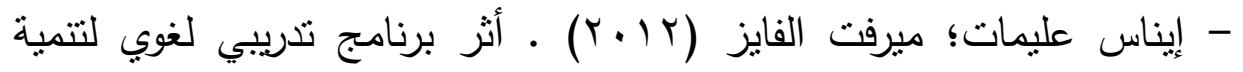

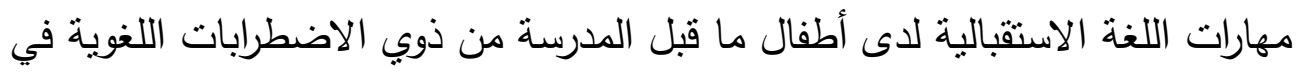

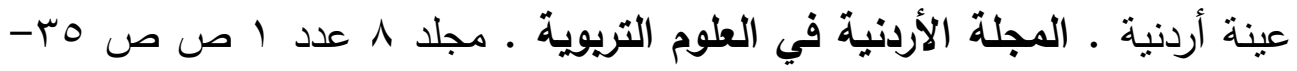

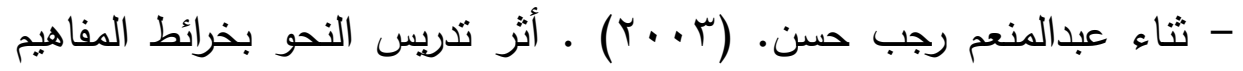

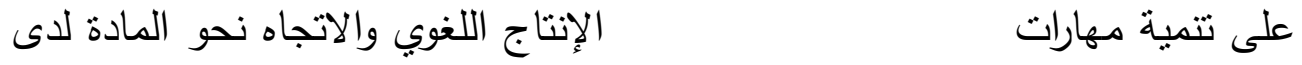
طلاب الصف الأول الإعدادي. مجلة دراسات في المناهج وطرق التدريس، الجمعية

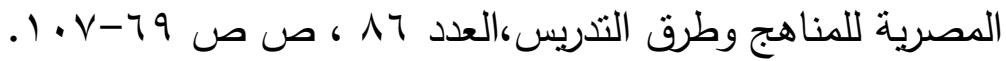

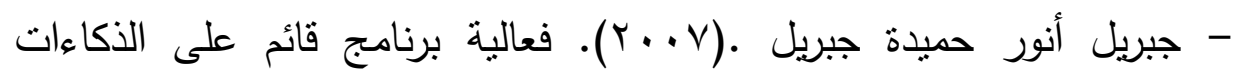
المنعددة في تتمية مهارات التحدث لدى تلاميذ المرحلة الإعدادية مرتقعي ومنخفضي مفهوم الذات اللغوية. رسالة دكتوراه غير منشورة، كلية التربية، جامعة

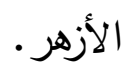

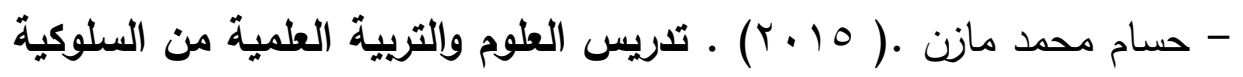
إلي البنائية. المنصورة: المكتبة العصرية.

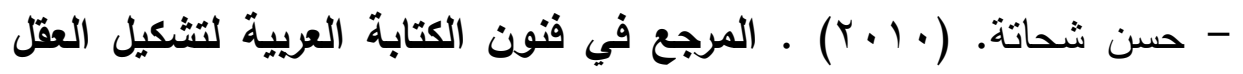

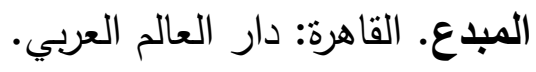

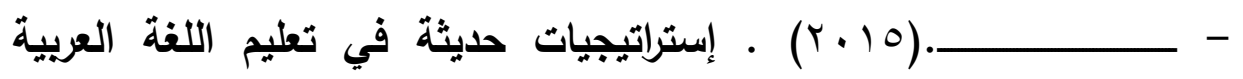
وتعلمها. القاهرة : الدار الدصرية اللبنانية. 
- رشدي أحمد طعيمة. (ع . . ب) .المهارات اللغوية، مستوياتها، تدريسها، صعوياتها. القاهرة: دار الفكر العربي. - زكريا إسماعيل.(11 • (1). طرق تدريس اللغة العربية ـ الإسكندرية: دار المعرفة الجامعية.

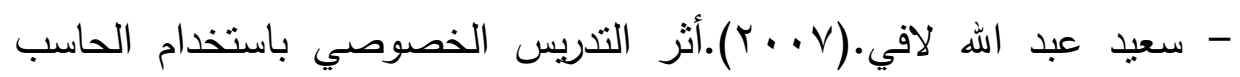
الآلي في تتمية الكفاءة اللغوية لدى تلاميذ المرحلة الابتدائية وتتمية اتجاهاتهم نحو اللغة العربية، مجلة دراسات في المناهج وطرق التدريس، العدد مباءه اله يونيو ، ص ص ص 10-7 7.

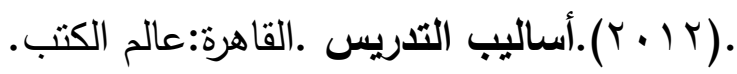

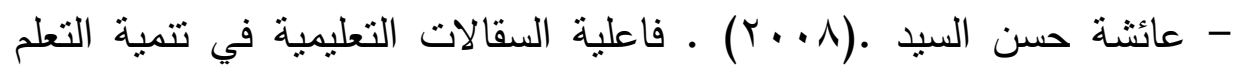
المتعق في تدريس العلوم للمرحلة الإعدادية. رسالة دكتوراة غير منشورة، كلية البنات، جامعة عين شمس. - عبدالقادر محمد السيد. (T/ (ץ). دراسة التفاعل بين السقالات التعليمية ومستويات التحصيل على مهارات التفكير الرياضي والاتجاه نحو المادة لدى تلاميذ الصف الخامس الأساسي، مجلة دراسات عربية في التربية وعلم النفس،

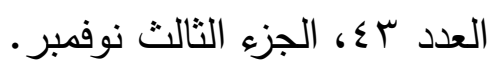

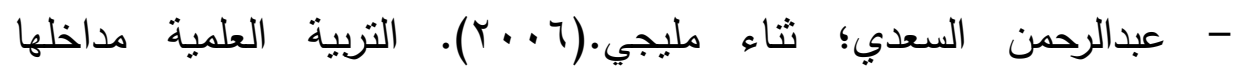
واستراتيجياتها. القاهرة: دار الكتب الحديث. - علي أحمد مدكور .(r . . r).التربية وثقافة التكنولوجيا ـ القاهرة : دار الفكر العربي. - قاسم البري. (11 + ( ) ـ أثر استخدام الألعاب اللغوية في منهاج اللغة العربية في تتمية الأنماط اللغوية لدى طلبة المرحلة الأساسية، المجلة الأردنية في العلوم

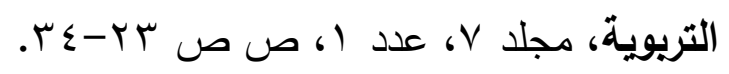




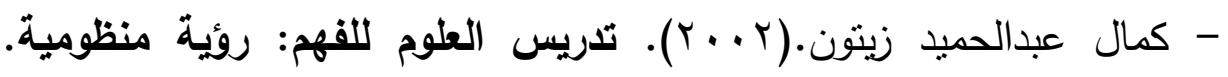

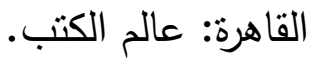

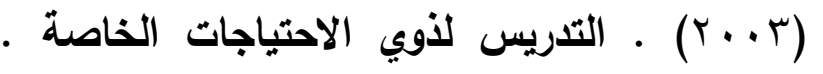

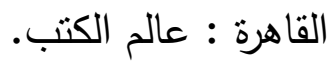

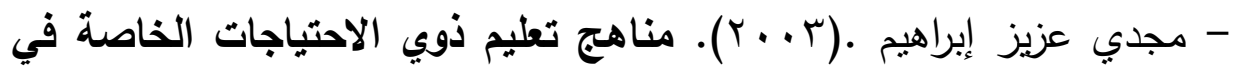
ضوء متطلباتهم الإنسانية والمعرفية. القاهرة: مكتبة الأنجلو المصرية.

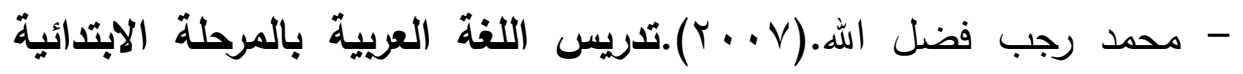
(معارف، ومهارات).كلية التربية، جامعة الإمارات.

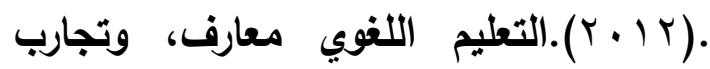

ويحوث ودراسات. القاهرة: عالم الكتب.

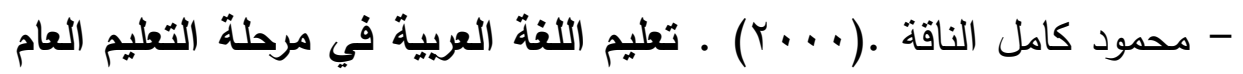
بجمهورية مصر العربية "دراسة وتقويم" ـ الموسم الثقافي الثاني عشر لمجمع اللغة العربية، الأردن. - مان. - منى إبراهيم اللبودي.( 0. . ب). فعالية استخدام إستراتيجية مناقثة المواد المقروءة في تتمية المحتوى الفكري في التعبير الكتابي لدى تلميذات المرحلة

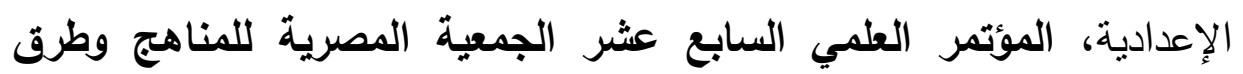
التدريس " مناهج التعليم والمستويات المعيارية" ـ القاهرة: دار الضيافة بجامعة

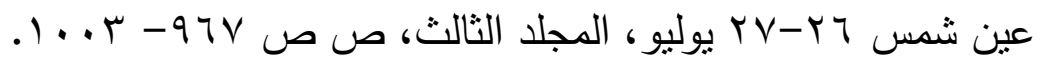

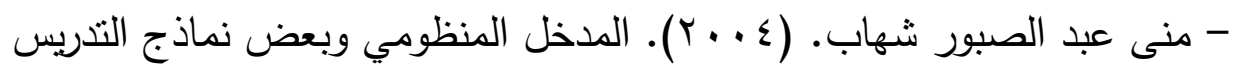
القائمة على الفكر البنائي. المؤتمر العربي الرابع. المدخل المنظومي في التدريس

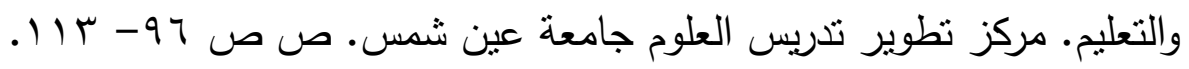

ثانيًا - المراجع الأجنبية:

- Dabbagh,N.\&Kitsantas,A.,(2005).Using Web-based Pedagoogical Tolls as Scaffolds For Self-regualted Learning. Instructional Science, 33,513- 540. 
- Gibson,Sharan A. (2011). Coaching Conversation: Enacting Instructional Scaffolding.Journal Mid- Westren Educational Researcher, V 24, N 1, p.p. 5- 20, EJ942904,ISSN: 1056-3997.

- Hannafin,M. (2001) . scaffolding performance in Epsss: Bridging theory and practice, In C. Montgomerie\& J.Viteli ( Eds. ), proccedings of world conference on Educational Multimedia, Hypermedia and telecommunications, chesapeake,VA:AACE, p.p. $658-663$.

- Jones,Nicole Alissa.( 2012).Preschool Educators' perceptions of Practice in Facilitating / Modeling Oral Language Acquisition and Development.proQuest LLC, Ed.D.Dissertation, Loyola University Chicago,p.163,E.D546310.

- Lajoie,S.P.(2005). Extending The Scaffolding Metaphor. Instructional Science, 33,513- 540.

- Mccartney,E.;Ellis,S.( 2013).The Linguistically Aware Teacher and the Teacher-Aware Linguist.Journal Clinical Linguistics\& Phonetics,v27, n6-7,p.p 419-427, EJ1005409.

- Mckenzie, Lolita D. ( 2011) . Scaffoldig English Language Learners'Reading Performance,ProQuest LLC, E.d.D. Dissertation, Walden University, p.115, ED536391, ISSN:N/A.

- Nippold,M.A.(2003). Mental Imagery and Idiom Comprehensions:a comparison of shool-age children and adults.journal of speech, language, and hearing Research,Vol.46, p.p.788-799.

- Nwosu B.O.; Azih Nonye.(2011). Effects of Instructional scaffolding on the Achievement of male and female students in financial accounting in secondary schools in abakaliki urban of 
ebonyi state, Nigeria current research journal of social sciences, 3(2), p.p. 66-70, ISSN : 2041- 3246.

- Zambrano Corzo; X.p.\& Noriega robles h.s .(2011).

Approaches to scaffolding in teaching mathematics in english with primary school student in 


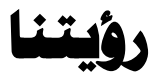

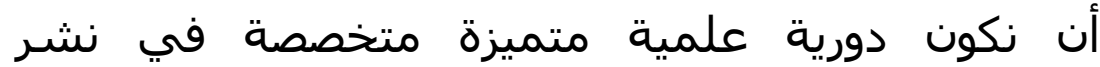

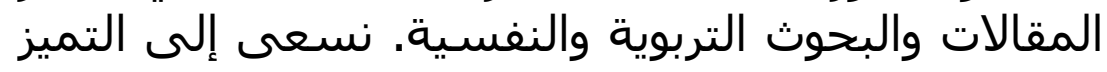

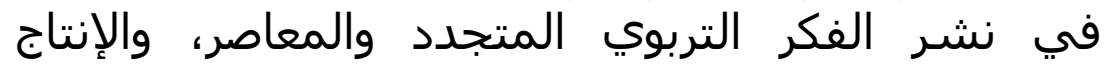
العلمي ذي الجودة العالية للباحثين في مجاليدي الفيدي: التربية

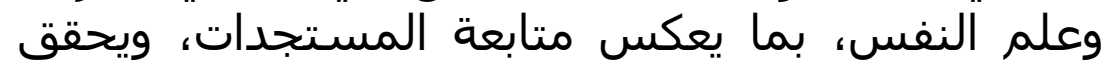
التواصل بين النظرية والتطبيق.

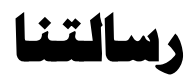

نشر وتأصيل الثقافة العلمية بين المتخصصين في

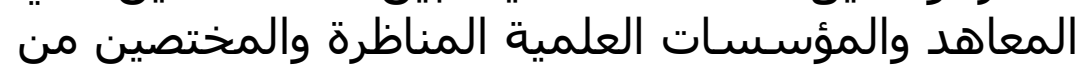

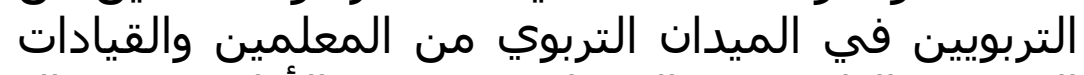

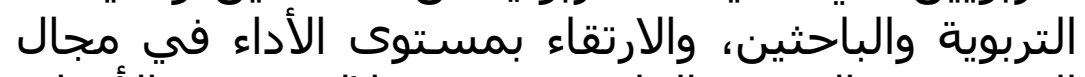

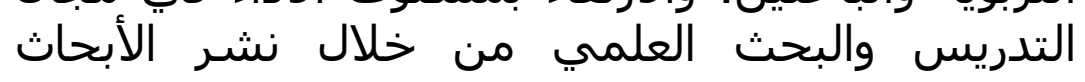

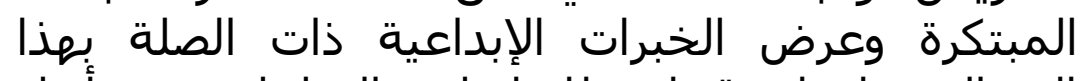

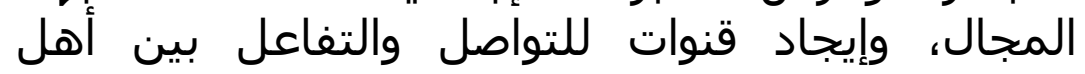

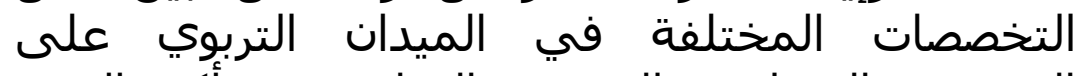

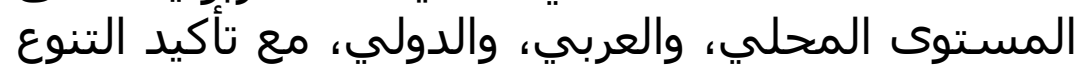

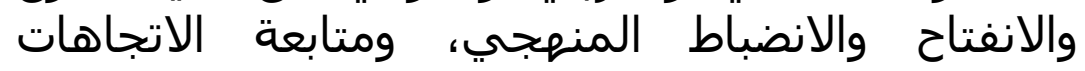

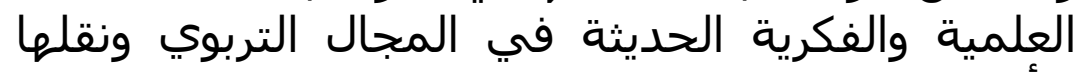

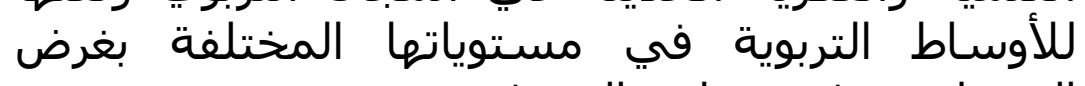
المساهمة في صناعة المعرفة.

\section{سياستسنا}

إتاحة فرص للنشـر والتداول على المستويات المحلية،

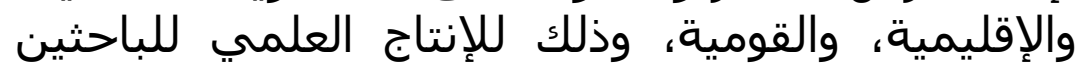

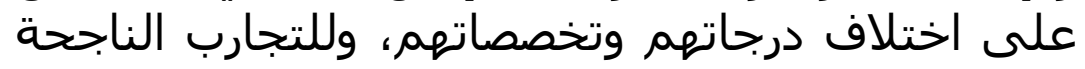

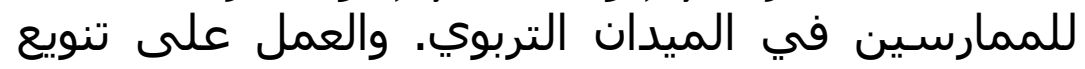

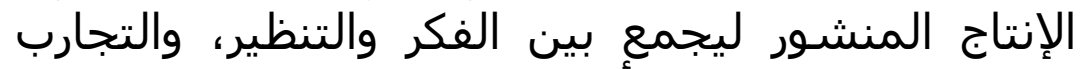

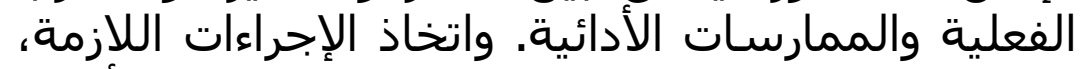

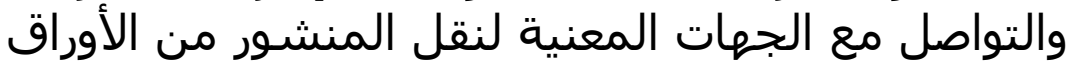

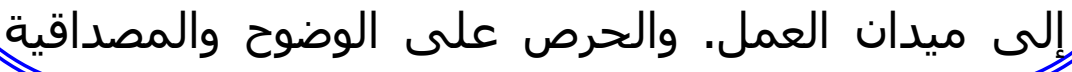


والتراصل الدائم مع الباحثين والمؤسـسات والميدان 